\title{
الفتاوى الشاذة وأثرها على الأمن الفكري
}

للدكتورة / نجائ عبدا لجواد صهوان

أستاذ مساعد بقسم الفقه العام بكلية الدراسات الإسلامية

والعربية للبنات بلدمنهور 
مجلة كلية الدراسات الإسلامية والعربية بنات - دمنهور العدد الثالث - الجزء الثاني 1^بrم

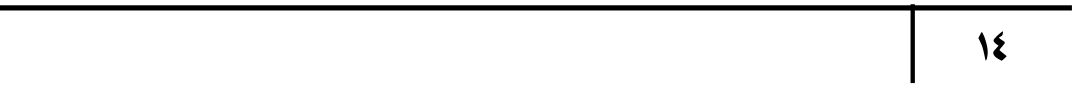




\section{(المقدمة)}

الحمد لله فاطر السماوات والأرض ، والصلاة والسلام على المبعوث

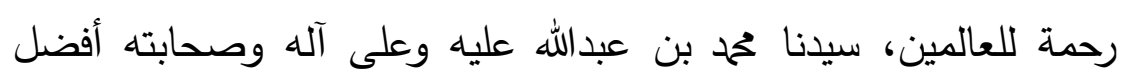
الصالاة وأزكى التسليم أما بعد : - مأو

فالدين الإسلامي هو دين الله الخالد الذي ارتضاه للبشرية ، واختاره

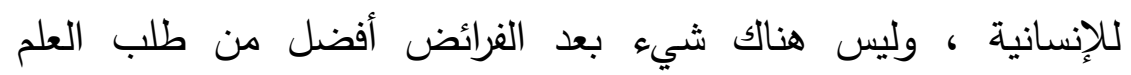

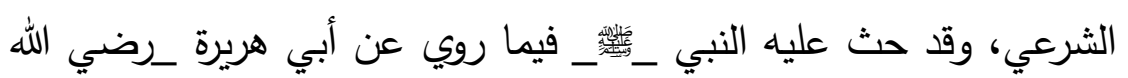

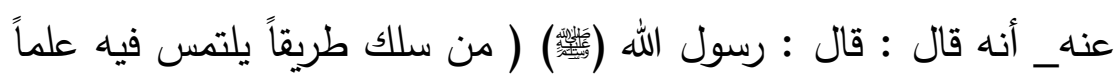

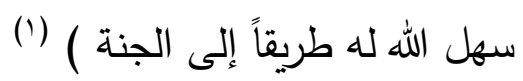
وعلم الفقه من أجل العلوم وأفضلها ، فهو علم يعرف به الستتباط

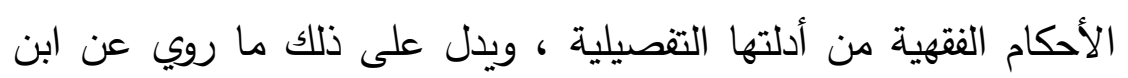

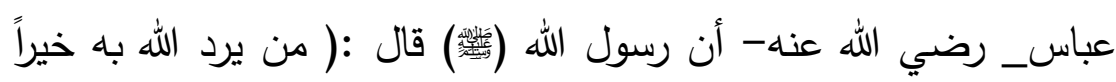
يفقها في الدين ) (r) والتصدر للإفتاء من أخطر الأعمال وأنبلها فالمفتى هو الموقع عن رب العبات

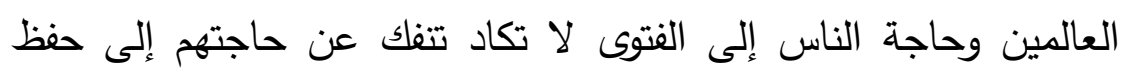

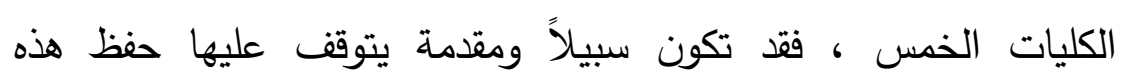
الكليات، ولهذا كان لضبط الفتوى أثر عظيم في حفظ الضرورات ، إلا أنه هله

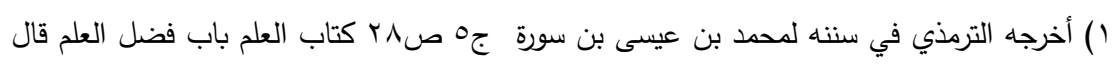

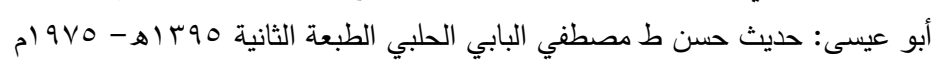

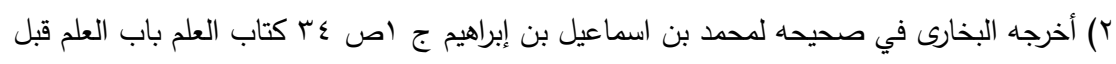

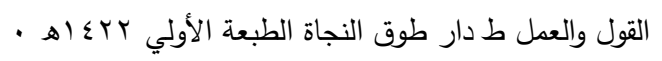


في الفترة الأخيرة ظهرت الكثير من الفتاوي الثاذة التى أثرت علي الأمن

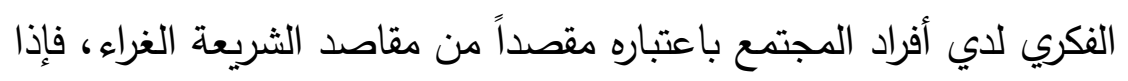

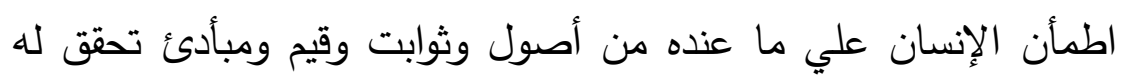

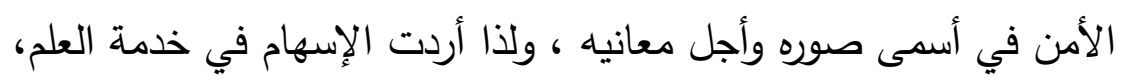

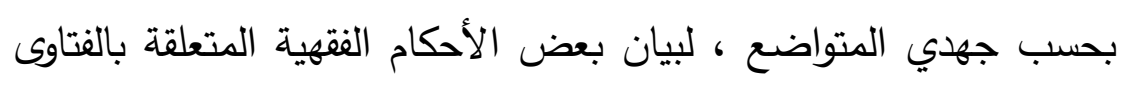

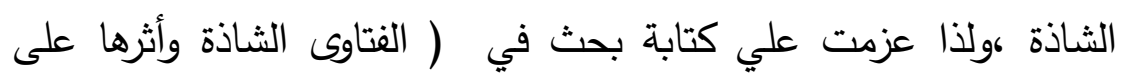

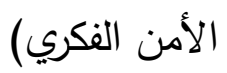

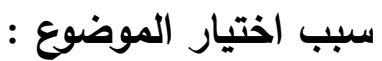

1- إبراز دور الشريعة الإسلامية وحرصها علي حماية فكر اتباعها من الن الوقوع في الأفكار الهدامة المنحرفة ـ الأبرات

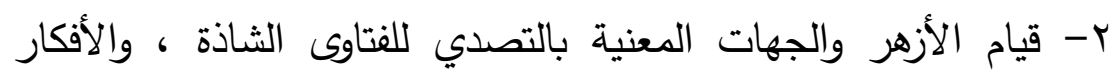

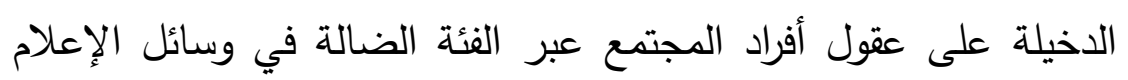
المتتوعة . المان

r- إيماني العميق بإظهار الأحكام الثرعية المواكبة للعصر ، وبيان أن الشريعة الإسلامية صالحة لكل زمان ومكان . ع- إثبات أن الفتوي لها أثر في أمن المجتمع وصونة ونكان من الإنه الانحرافات الفكرية .

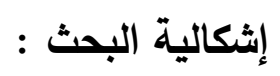
تواجه المجتمعات الإسلامية اليوم إشكالية كبيرة وهي خروج الفتوي عن

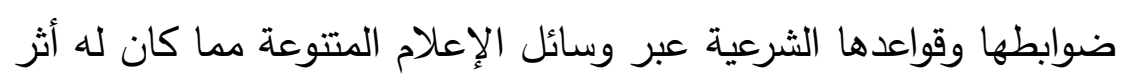

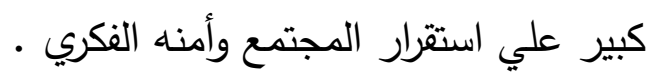
الداسات السابقة : هناك أبحاث كثيرة تناولت الفتاوي الثاذة منها : 
1- الفتاوي الشاذة وخطرها للدكتور /على أحمد السالوسى •

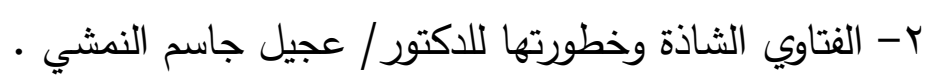

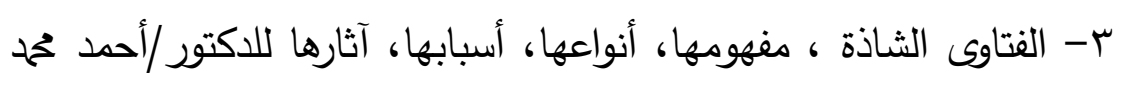

هليل . ه

ع- الفتاوى الثاذة تلهى الأمة وتضيع هيبة العلماء ويصعب تداركها في

عصر الإعلام المفتوح لتركى المطيري .

أما الأبحاث التي تتاولت أثر الفتاوي الثاذة علي الأمن الفكري

فهي محدودة أهمها:

1- الثذوذ في الفتوي وأثثه علي الأمن الفكري للمجتمعات الإسلامية

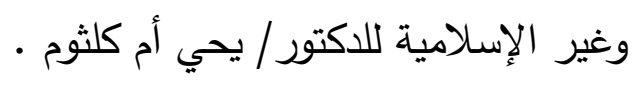

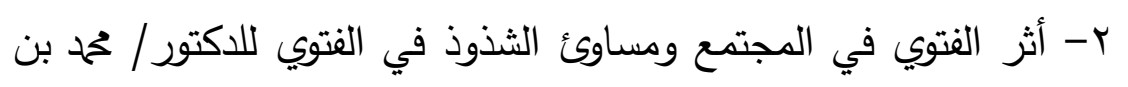

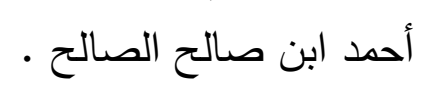

وقد أردت في البحث التعريف بالفتوى الصحيحة وشروطها وأثرها علي الأمة ، وفي المقابل التعريف بالفتاوى الثاذة ومعايير وصف الفتوي

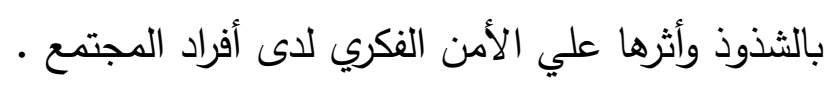

$$
\text { منهج البحث : بالمدود }
$$

المنهج الملائم للبحث هو المنهج الوصفي التحليلي ، حيث يقوم

على وصف الظاهرة ، وتحليلها إلى عناصرها المكونة لها ، ثم استخلاص النتائج المترتبة عليها، مع مراعاة عرض المادة الفقهية وعزو كل قول إلى

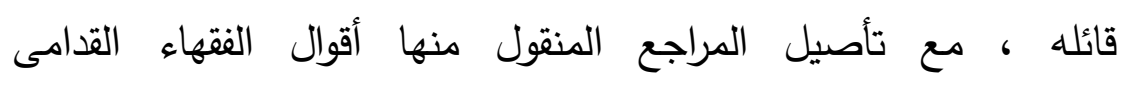

$$
\text { أو المعاصرين }
$$

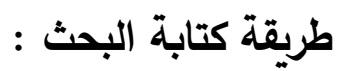

1- عزو الآيات القرآنية إلى سورها ، بذكر اسم السورة ورقم الآية . 
ץ- تخريج الأحاديث النبوية وآثار الصحابة من كتب السنة المعتمدة

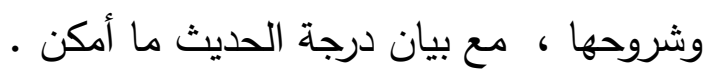

ب- ترتيب المذاهب الفقهية حسب الترتيب الزمنى لها ،هع ذكر أدلة كل مذهب وترجيح الأقوى دليلاً المحقق للمصلحة العامة من غير تعصب

$$
\text { لمذهب معين }
$$

ع- قمت بترجمة موجزة للأعلام غير المشهورين الوارد ذكرهم في البحث. 0- قمت بتعريف بعض المصطلحات اللغوية ، والفقهية ، والأصولية.

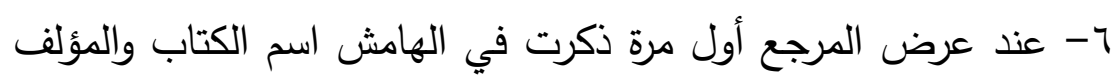

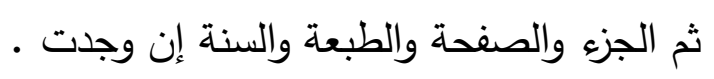
ق قمت بعمل خاتمة ، وفهرس للمراجع ، وأخر للموضوعات و -V خطة البحث : وتثتمل على المقدمة وثلاثة فصول : المقدمة تشتمل علي : أهمية البحث، وسبب اختيارالموضوع ، واشكالية البحث ، والدراسات السابقة ، ومنهج البحث وطريقة كتابة . الفصل الأول: ( التعريف بمفردات البحث ) ويشتمل علي ثلاثة مباحث : المبحث الأول / تعريف الفتاوى الشاذة . التعردي المبحث الثاني / تعريف الأثر / المبري

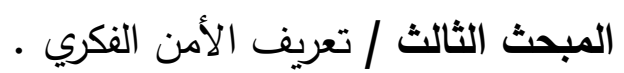
الفصل الثانى ( أهمية الفتوي وشروطها، وأسباب شذوذ الفتوي، ومعايير اعتبارها شاذة ) ويشتمل على أربعة مباحث :

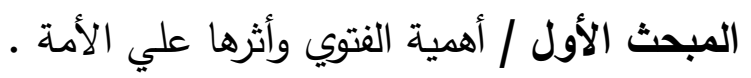

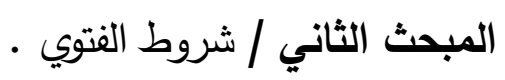
المبحث الثالث / أسباب شذوذ الفتاوى . لتموط ل 


\section{الفتاوى الشاذةوأثرها على الأمز الفكرى}

المبحث الرابع / معايير وصف الفتوى بالثذوذ .

الفصل الثالث ( أهمية الأمن الفكري ، والجهات المنوطة به ، وأثر الفتاوى الثاذة عليه ، وبعض قرارات مجمع الفقه الإسـلامي والمؤتمرات الخاصة بالإفتاء ) ويشتمل على أربعة مباحث :

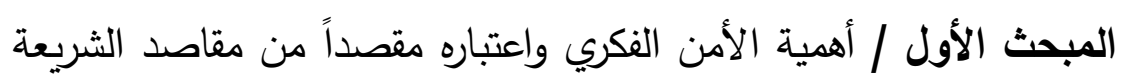

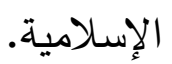

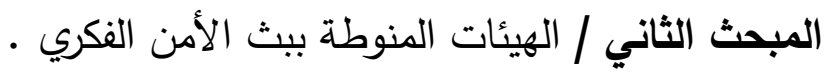
المبحث الثالث / أثر الفتاوى الثاذة على الأمن الفكري . المبحث الرابع / بعض قرارات مجمع الفقه الإسلامي والمؤتمرات الخاصة بالإفتاء .

الخاتمة وتثتمل علي أهم النتائج والتتوصيات . فهرس للمراجع ، فهرس للموضوعات . 


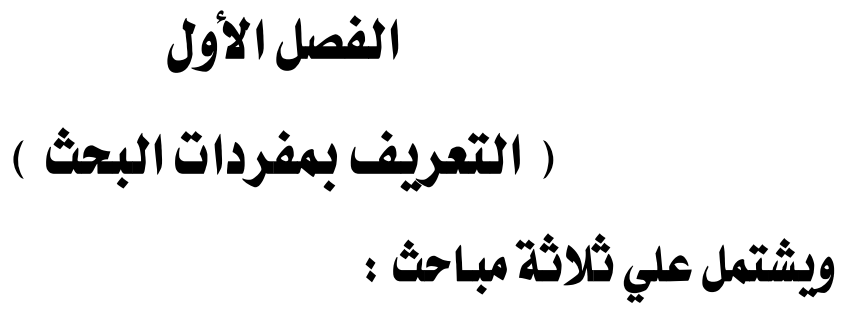

المبحث الأول / تعريف الفتاوى الشاذة .

المبحث الثاني / تعريف الأثر .

المبحث الثالث / تعريف الأمن الفكري 


\section{المبحث الأول / تعريف الفتاوى الشاذة}

الفتاوى الثاذة مصطلح مركب أبدا بتعريفهما مفردين ثم مركبيين :

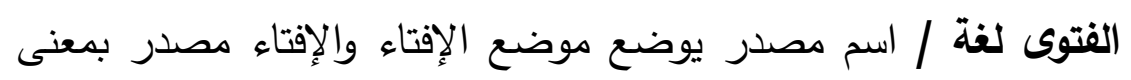
التبيين والفتوى هي : ما أفتي به الفتيه يقال : أفتى في المسائل أبان (1) الحكم فيها

الفتوي اصطلاحاً / إخبار عن الله في إلزام أو إباحة .(؟)

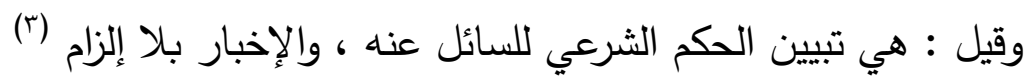

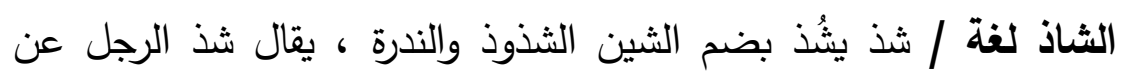
الجماعة أي انفرد عنهم وهو من شواذ القوم ، وأشذ فلان جاء بقول شاذ ،

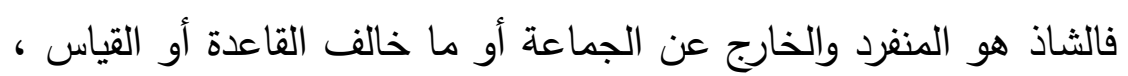
والجمع شواذ ، وشَذ بفتح الثين هو المتفرق من الحصى وغيره وشذان

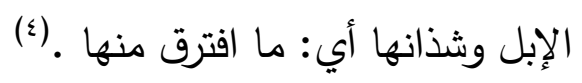

( ) لسان العرب لأبو الفضل جمال الدين بن منظور الأفريقي جr ص آب ط دار صادر الطبعة

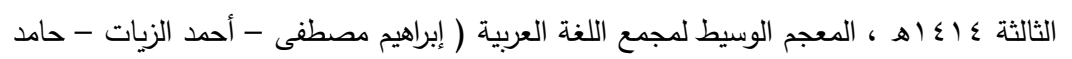

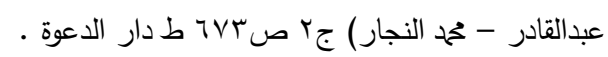

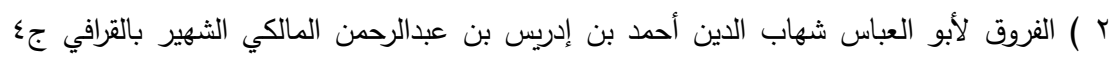

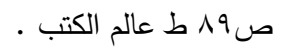
r ) مطالب أولى النهى في شرح غاية المنتهي لمصطفى بن سعد بن عبده السيوطي الرحيباني الحنبلي

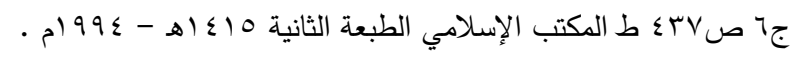

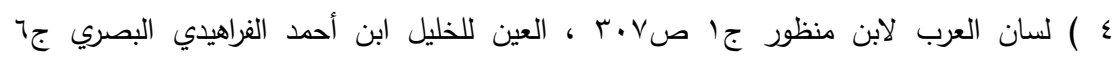

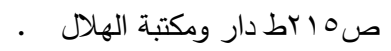


الثاذ اصطلاحاً / ورد بعدة تعريفات

1- القـول الثـاذ عنـــ الفقهـاء: مـا كـان مقـابلا للصــيح أو المشـهور أو الراجح أى أنه الرأي الضعيف أو الغربب أو ما هو مخالف لما عليه

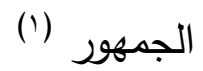

r) بيل هو : ما خالف فيه صاحبه أقوال سائر الفقهاء ـ (r) ب- قيـل : هـو الـــي لـيس مــع قائلــه دليـل مـن كتــاب الله ولا ســنة

رسول الله

وبالنظر في التعريفات السابقة أرى أن الشاذ هو : هو ما خالف فيه صاحبه أقوال سائر الفقهاء ولا يعتمد فى قوله علي دليل من أدلة الشرع هور هون - المعتبرة

فـالتعريف الأول والثاني قصـر الثـذوذ في القول علي مـا كـان مقـابلا للصحيح أو هو الرأي الضعيف أو الغريب أو مخالفة أقوال سائر الفقهاء

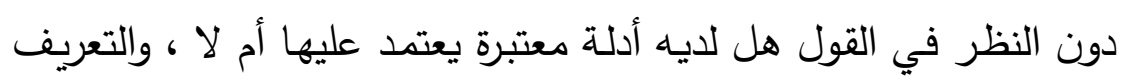

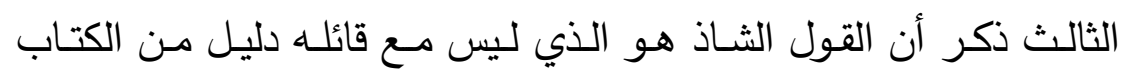

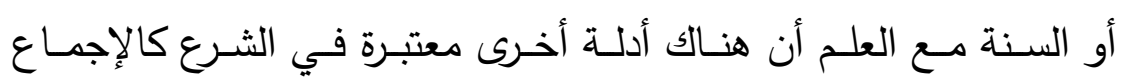
والقياس والعرف وغيرها من الأدلة الشرعية .

() رد المحتارعلي الدر المختار لمحد أمين بن عمر الشهير بابن عابدين جا ص ط ط طدار الفكر

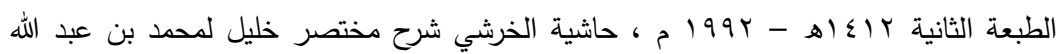

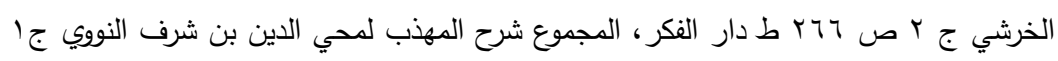

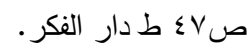

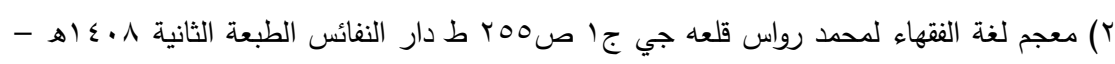
- م) $9 \wedge 1$

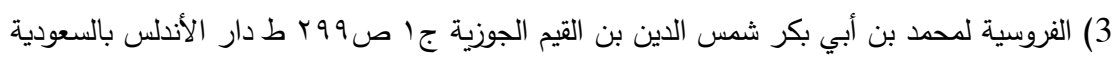

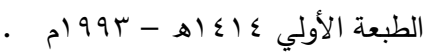




\section{الفتاوى الشاذةوأثرها على الأمن الفكرى}

\section{تعريف الفتاوى الثاذة مركباً:}

مصطلح الفتاوى الشاذة مصطلح حديث لم يعرف عند الفقهاء القدامي ؛ وذلك لإشتراطهم في المفتي شروطا يبعد معها أن يقع في فتوى أو قول أو

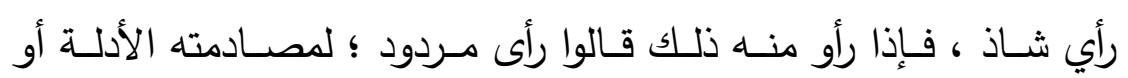
مقاصد الثرع ومبادئه .

أما الفقهاء المعاصرين فقد وضعوا لها عدة تعريفات منها: 1- استحداث فتاوى خاطئة في الدين تؤدي بالأخذين بها إلي الجراءة

على اقتحام حمى الله . (1)

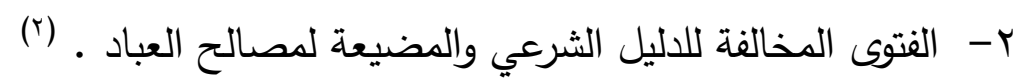
بالنظر في التعريفين المذكورين أرى أن التعريف الثاني هو الراجح ؛ حيث

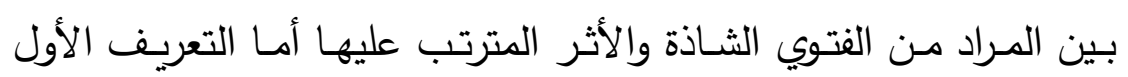

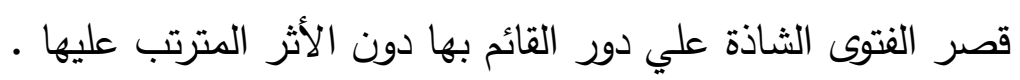

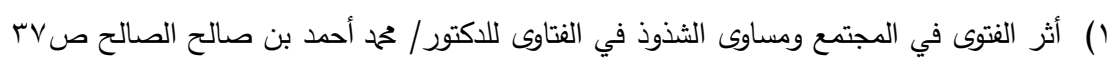

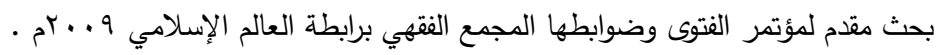

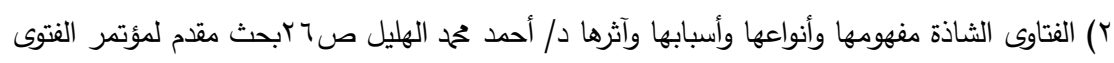

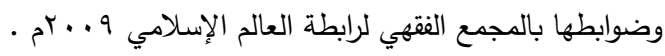




\section{المبحث الثاذي / تعريف الأثر .}

الأثر لغة / يطلق على عدة معانٍ منها

1- بقية الثيء أي : ما بقى من رسم الثيء .

$$
\text { • ب- ذبر الثيء }
$$

r- الخبر ، وسنن النبي ، وآثاره •

والتأثر هو / إبقاء الآثر في الثىء ، يقال: أثر في الثـي أى ترك فيه

(أثراً . (1)

الأثر اصطلاحاً/ لا يخرج استعمال الفقهاء للفظ أثر عن المعاني اللغوية،

$$
\text { وأكثر ما يستعمل : }
$$

1- للالالة على بقية الثيء ، أو ما يترتب على الثىء وهو المسمى

(r). بالحكم

r- الأثر: بمعني النتيجة المترتبة علي التصرف وحصول ما يدل علي

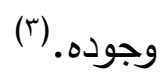

والتعريف المختار للأثر والذى يتفق مع البحث هو النتيجة المترتبة علي التصرف

( ) لسان العرب لابن منظور جء صه ، معجم مقاييس اللغة لأحمد بن فارس بن زكريا القزويني جا

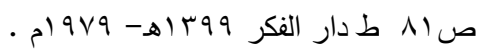

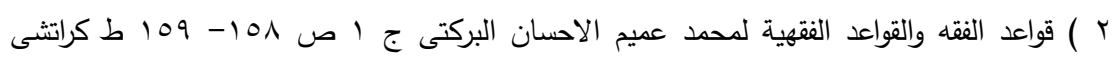

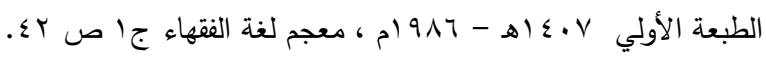

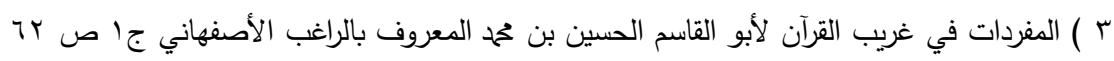

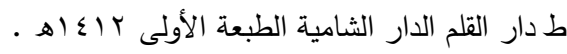




\section{المبحث الثالث / تعريف الأمز الفكري}

الأمن الفكري مصطلح مركب أبد بتعريفهما مفردين ثم مركبيين :

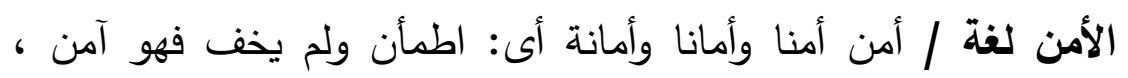
وآمنت غيري من الأمن والأمان، والأمن : ضد الخوف ، والأمانة : ضد المن واندانه الخيانة ويقال : لك الأمان أي: قد أمنتك ، والبلد اطمأن فيه أهله ، والثر

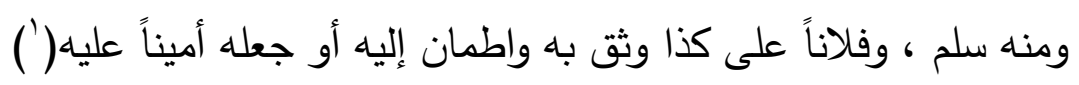

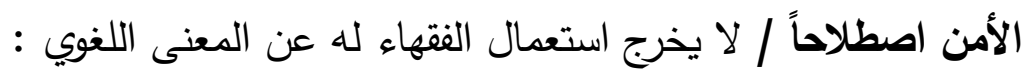
قيل : هو عدم توقع مكروه في الزمان الآتى (r). قيل : هو طمانينة النفس وزوال الخوف (r). قيل : سكون القلب عن توقع الضُر (ء). الفكر لغة / هو نشاط ذهني إعمال للعقل في العلوم للوصول إلى معرفة

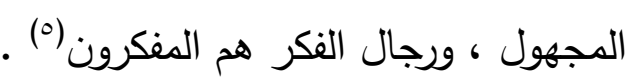
الفكر بالكسر تردد القلب بالنظر والتدبر لطلب المعاني ، يقال : لي في الأمر فكر أي: نظر ورؤية . بردئ

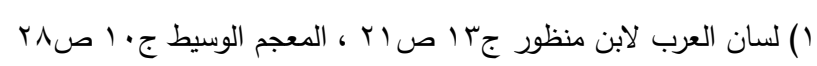

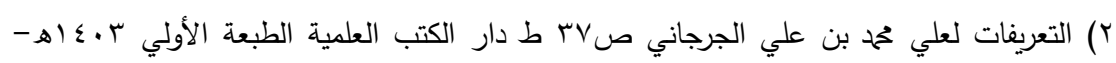
م) $9 \wedge \mathrm{r}$

r) التوقيف من مهمات التعاريف لمحمد عبد الرؤف المناوي صبآط عالم الكتب الطبعة الأولي

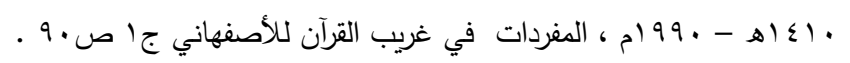

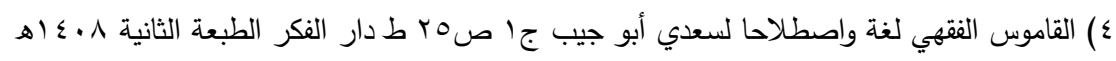
- م) $9 \wedge 1-$ 0) معجم اللغة العربية المعاصرة لأحمد مختار عبد الحميد عمر جr صع إ ط عالم الكتب الطبعة

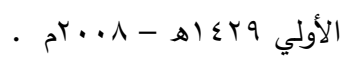


الفكر اصطلاحاً / ترتيب أمور حاصلة في الذهن يتوصل بها إلى أمور

مستحصلة ، وقد يطلق على حركة النفس من المطالب إلى المبادى ('). وقيل : حركة النفس من المطالب إلى الأوائل والرجوع منها إليها (؟). تعريف الأمن الفكري مركباً : يعتبر الأمن الفكري من المصطلحات

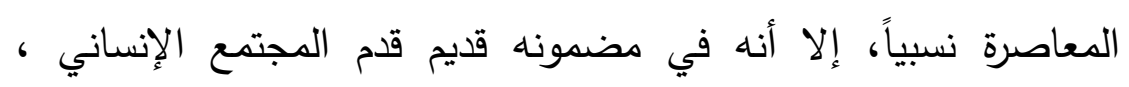
فالتعاريف كلها تدور حول هدف واحد : هو انضباط عملية التفكير لدى الأفراد والباحثين في إطار الثوابت الأساسية في الإسلام وبما يخدم هذا التفكير ويبنيه ولا يهذمه (r). قيـل : هـو سـكون وطمانينـة الأمــة علـى عقيـدتها وفكرهـا وهويتهــا وثقافتها (乏) قيل : هو سلامة فكر الإنسان وعقله وفهمه من الانحراف ، والخروج عن الوسطية والاعتدال في فهمه للأكور الدينية والسياسية بعيداً عن الغلو ولونه والتنطع أو الالحاد (०). والتعاريف جميعها لا تخرج في مدلولها الكلي عن الوسطية في التفكير في ضوء الثوابت الثرعية لحفظ الأمن والإيمان .

( ) بيان المختصر شرح مختصر ابن الحاجب لمحمود عبدالرحمن شمس الدين الأصفهاني جا صل

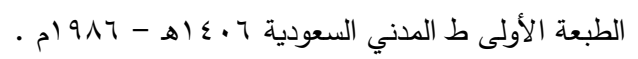

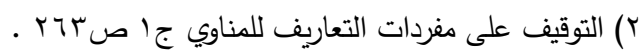
r ) دور حلقات تحفيظ القرآن الكريم في تعزيز الأمن الفكري رؤية مستقبليه د/ على على بن فايز الجحني

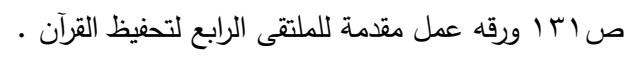

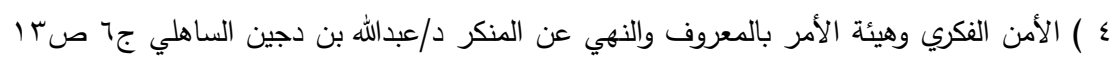

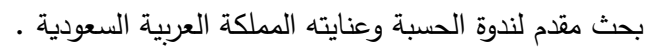

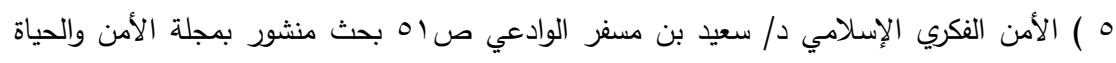

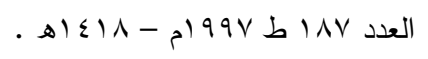




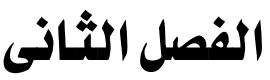

( أهمية والفتوى وشروطها ، وأسباب شذوذ الثتوي ، ومعايير

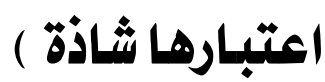

$$
\text { ويشتمل على أربعة مباحث : }
$$

المبحث الأول / أهمية الفتوي الشرعية وأثرها علي الأمة

المبحث الثاني / شروط الفتوى .

المبحث الثالث / أسباب شذوذ الفتوى .

المبحث الرابع / معايير وصف الفتوى بـالشذوذ 


\section{المبحث الأول ( أهمية الفتوي الشرعية وأثرها علي الأمة )}

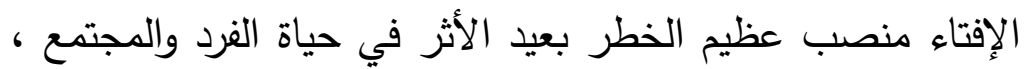

ولعظم خطره قد تولاه الله بنفسه وصرح بذلك في محكم كتابه قال تعالي :

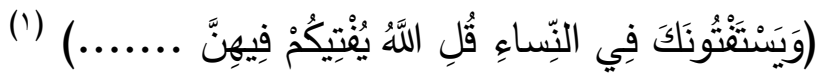

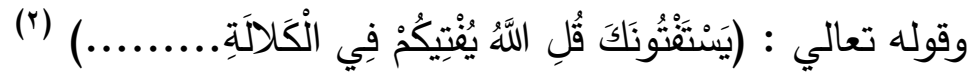
وقد تولي النبي ( صلي الله عليه وسلم ) هذا المنصب في حياته

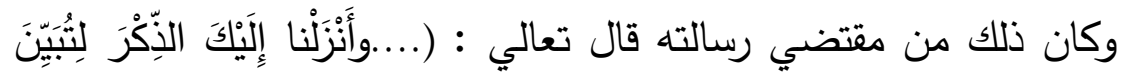

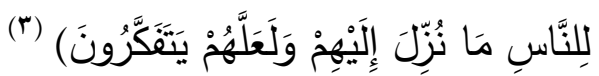
وقد تولي الخلافة بعد النبي ( صلي الله عليه وسلم ) أصحابه الكرام ثم أهل العلم من الفقهاء والمفتين، فالمفتي هو ملاذ العامة يلجئون إليه عند نزول النوازل بهم لاستجلاء الحكم الشرعي ويدل علي ذلك :

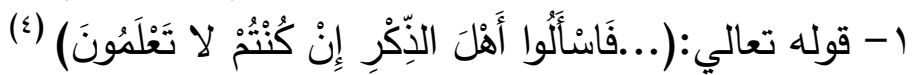

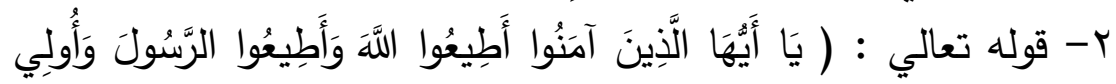

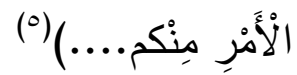

\section{وجه الدلالة من الآيتين :}

في الآية دليل علي وجوب الرجوع إلي أولى الأمر وأهل الذكر وقد

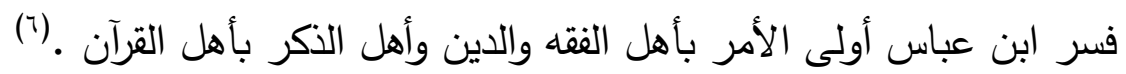

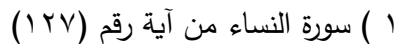

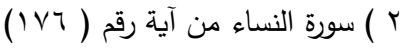

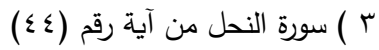

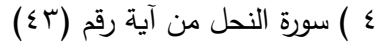

$$
\begin{aligned}
& \text { ( ) سورة النساء من آية رقم (109) }
\end{aligned}
$$

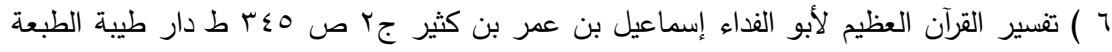

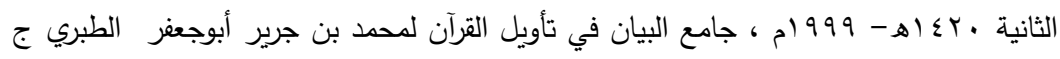

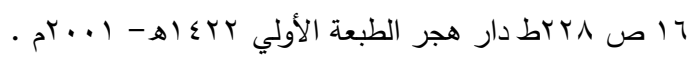


ولذلك شبه القرافي المفتي بالترجمان (')

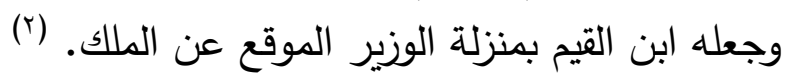

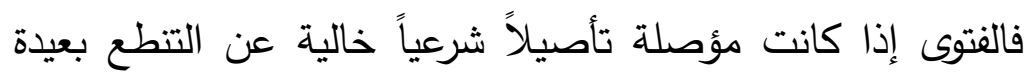
عن الأقوال الثاذة قوية بالأدلة مراعى فيها رضا الحق ومصالح الخلق تاصلق

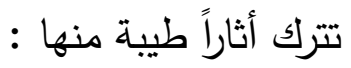
1- إزلة الجهل وتعلم بعض الأحكام الثرعية فالفتوى نوع من المدراس : الثراس

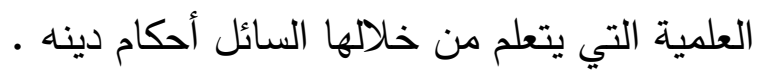

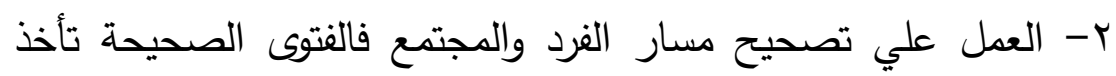
بأيدي الناس إلى الطريق القويم وتبعدهم عن البدع الذميمة والأفكار المتطرفة.

ب- توثيق صلة الأمة بعلمائها فالفتوى السلمية توثق صلة الأمة بعلمائها وتربطهم بولاة الأمر في شئون دينهم وما أحوج الأمة إلى ذلك

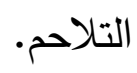
ع- إعانة المسلمين على أداء التكاليف الشرعية على الوجه الصحيح فكلما كانت الفتوى سديدة ومعتمدة على الأدلة الصحيحة فإنها تكون أدعى على حمل الناس على أداء التكاليف الثرعية على الوجه الذي الذي التهدي

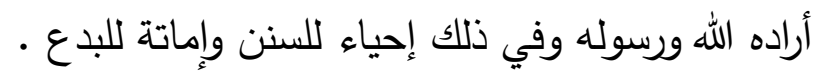

1 ) ويدل علي ذلك ما جاء في الفروق ما نصه : ( فالمفتي مع الله تعالي كالمترجم مع القاضي ينقل

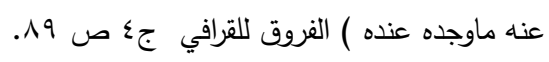
r ) ويدل علي ذلك ماجاء في إعلام الموقعين ما نصه: (إذا كان منصب التوقيع عن الملوك بالمحل

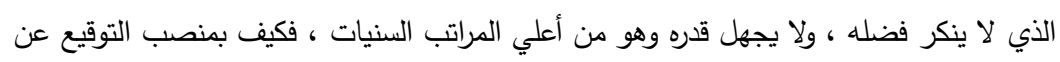

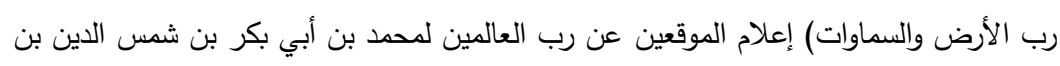

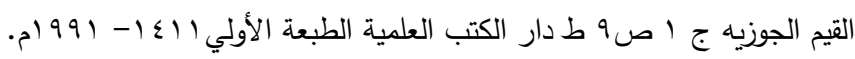




\section{المبحث الثاني ( شروط الفتوي )}

وضع الفقهاء شروط عدة للفتوي منها ما يتعلق بالمفتي، ومنها ما يتعلق بالمستقتي ، ومنها ما يتعلق بزمان ومكان الفتوي : أولا شروط لتروط (المفتي (1) 1- أن يكون المفتي مسـماً بالغـاً عـاقلاً ، فـلا يصـح الفتيـا مـن الكـافر

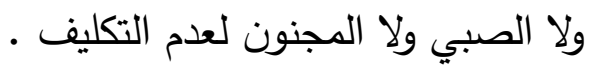

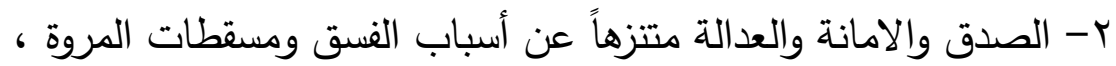
فلا تصح الفتيا من الفاسق عند جمهور الفقهاء من ( المالكية -

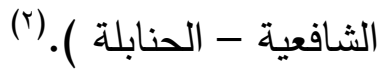

وذهب الحنفية: إلى أنه يجوز أن يكون الفاسق مفتياً؛ لأنه يجتهر كل

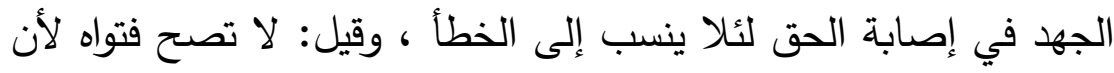
الإفتاء إخبار في أمور الدين وخبره غير مقبول في الديانات(؟)

( ) الأصول في علم الوصول لمحمد بن صالح بن محم العثيمين جا صبم ط دار ابن الجوزي

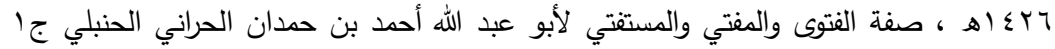

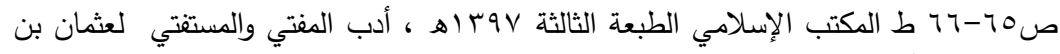

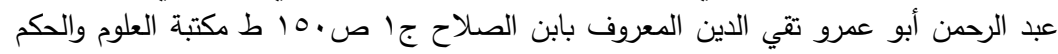

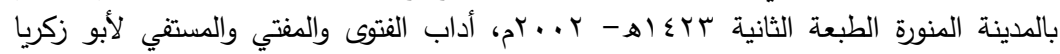

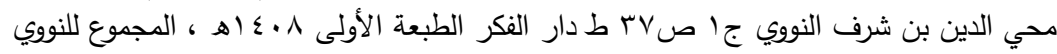

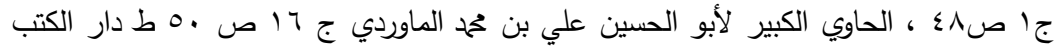

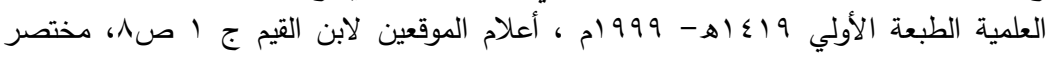

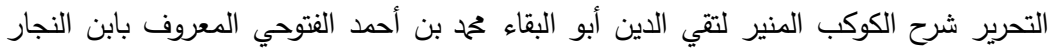

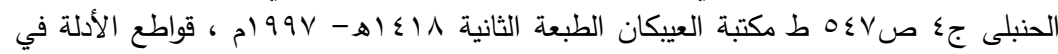

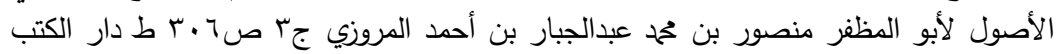

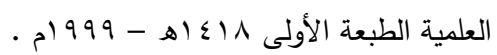

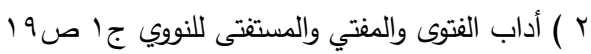

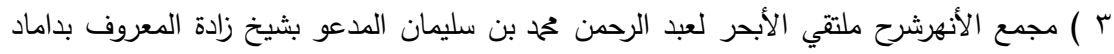

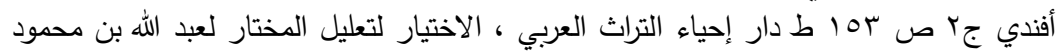

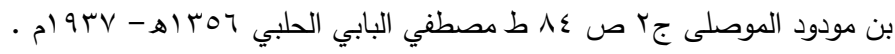


وإذا علم منه الفسوق ، وغلب عليه ، ودعا إليه فلا تقبل فتواه فالواجب

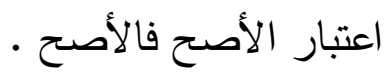

ويدل على ذلك ما ذكره ابن القيم ما نصه :( وفى جواز استقتاء مستور الحال وجهان ، والصواب جواز استفتائه وافتائه قلت : وكذلك الفاسق

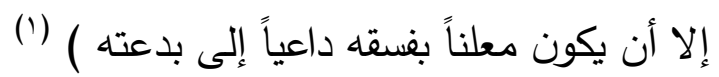
أما المبتدعة فلا تصح فتواهم بحال من الأحوال ويدل علي ذلك ما ذكره الخطيب البغدادي ما نصه : ( وتجوز فتاوى أهل الأهواء ومن لا تخرجه بدعته إلى فسق ، فأما الشراة والرافضة الذين يشتمون الصحابة ويسبون

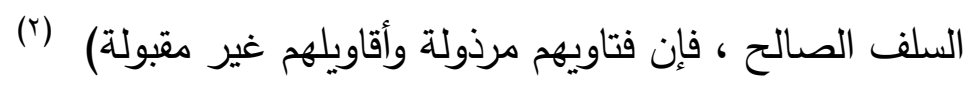
r- أن يكون المفتي من أهل الإجتهاد ، ويكون من أهل الاجتهاد إذا

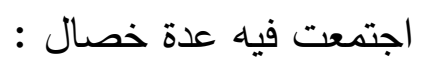
أ / العلم بكتاب الله ومعرفة الناسخ والمنسوخ منه ومتثابهه ومفسره ومجمله وعمومه وخصوصه . ب / العلم بالسنة النبوية ومعرفة أخبار التواتر والأحاد وصحة الطرق ومات والإسناد وما تقدم وما تأخر وما كان منها بسبب وما كان بغير سبب.

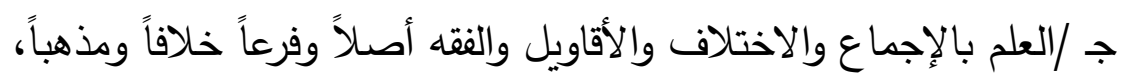
فقيه النفس سليم الذهن رصين الفكر قادراً على استباط الأحكام من الأدلة عالماً بما يشترط في الأدلة ووجوه دلالتها ويدل على ذلك قول

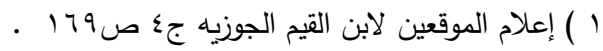

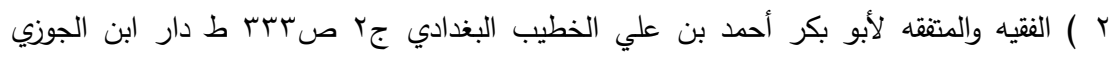

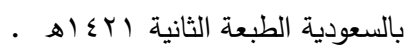


يحيي بن سلام ما نصه : (لا ينبغي لمن لا يعرف الاختلاف أن

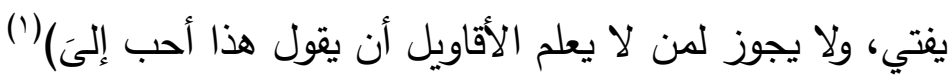

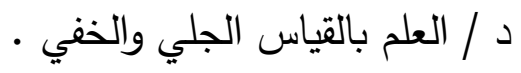

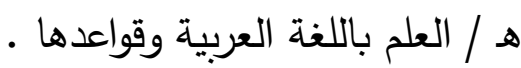

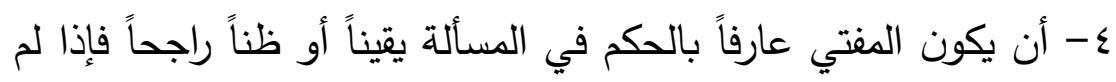

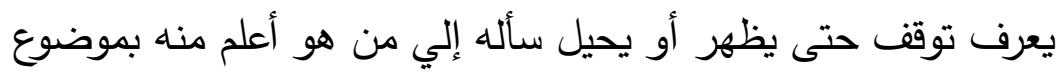

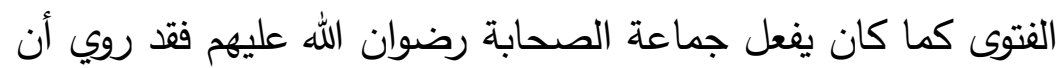

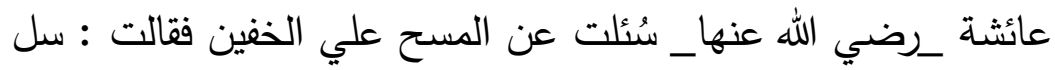
علياً _رضي الله عنه_ فإنه كان يسافر مع النبي ( صلي الله عليه

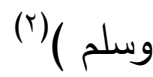

0- أن يكون هادى البال ليتمكن من تصور المسألة وتطبيقها على الأدلة

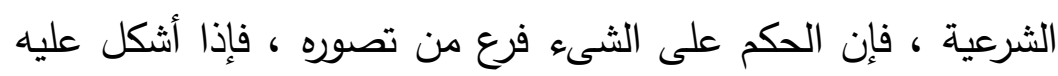

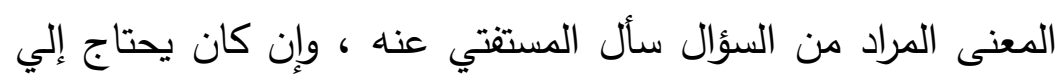

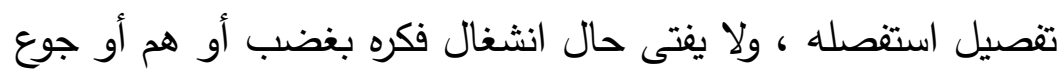
أو عطش أو نعاس أو مرض ، فكل أمر يخرجه عن حال الاعتدال

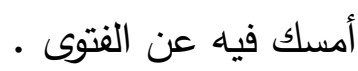
צ- أن يذكر المفتي في فتواه الحجة إذا كانت نصاً واضحاً مختصراً أما الأقيسة وشبهها فلا ينبغي أن يذكر شيئا منها.

( ) الموافقات لابراهيم بن موسى اللخمي الغرناطي المعروف بالشاطبي جه صبr أط دار ابن عفان

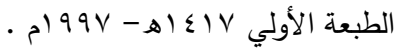

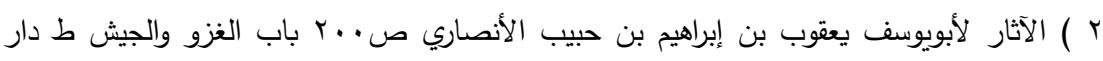

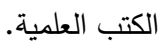


V- رجوعه عن فتواه إذا تبين له أنه أخطأ فيها، فإن كان خطؤه لعدم أهليته أو كان أهلا له ولم يبذل جهده يكون أثما ، وإن كان أهلا للاجتهاد فأخطأ فلا إثم عليه بل له أجر اجتهاده قياسا علي ما ورد في خطأ القاضي ، لما روي عن عمرو بن العاص أنه سمع رسول الله (صلي الله عليه وسلم ) يقول : ( إذا حكم الحالكم فاجتهد ثم

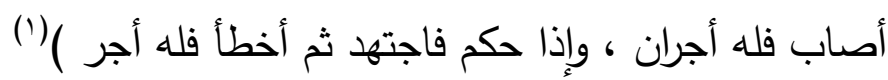

ثانياً شروط المستفتي : 1- أن يغلب على ظن المستفتي أن من يستفته من أهل الإجتهاد والعدالة

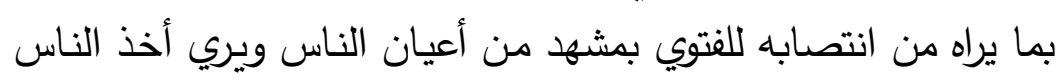

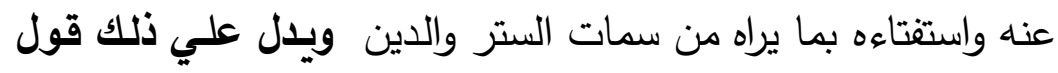

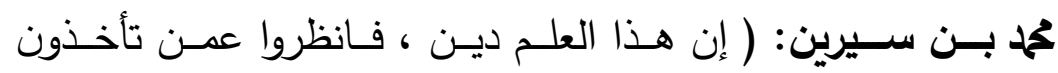

$$
\text { (r) (بن) }
$$

وليس للعامي أن يستفتي من يظنه غير عالم ولا متدين •

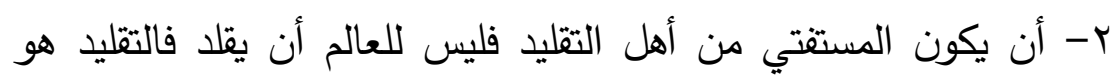

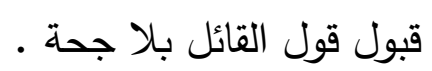

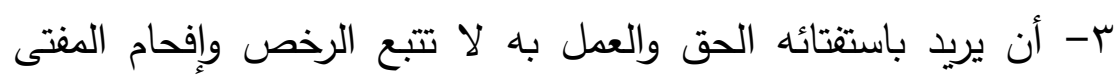

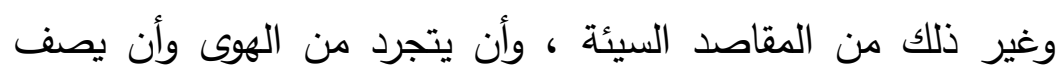
حالته وصفاً صادقاً دقيقاً فقد يدفع المستفتي للهوى لتزين بألفاظ حسنة ليغرر بالمفتي حتى يسوغ له ذلك فينبغي أن يكون المفتى فطناً لذلك

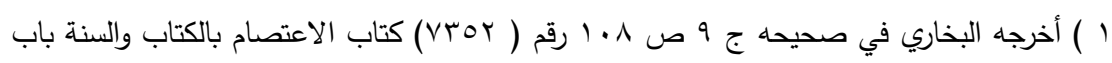

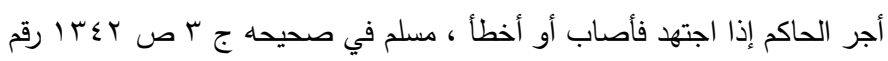

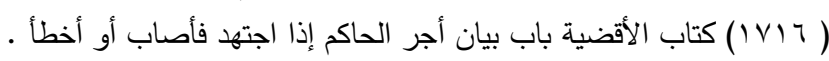

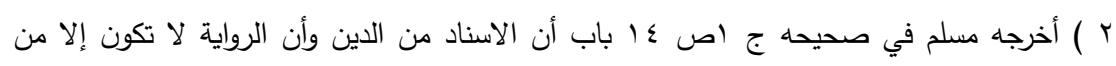


ويدل على ذلك قول ابن القيم ما نصه : (وبالجملة فليكن حذراً فطناً

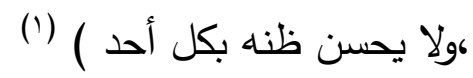

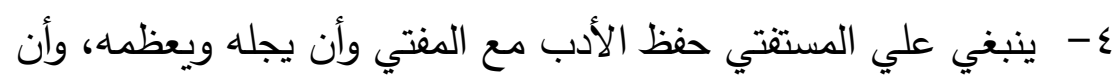

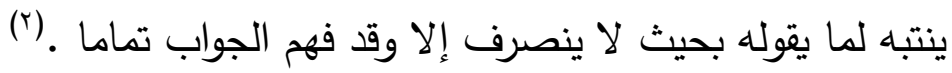

ثالثا شروط تتعلق بزمان ومكان الفتوي :

قد تتغير الفتوي بتغير الزمان والمكان إذا كان الحكم مبنيا علي عرف الناس وعادتهم ، ولذلك اشترط الفقهاء والأصولين في الدفتي الذي لإني

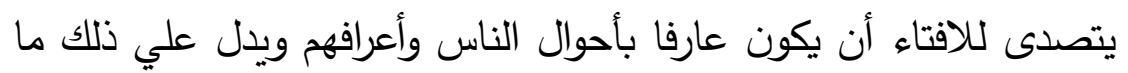

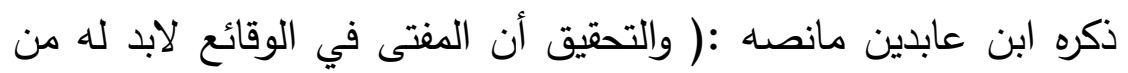

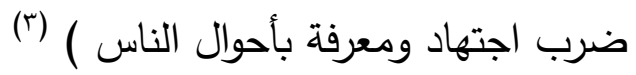

فهناك كثير من الأحكام الاجتهادية ذات ارتباط وثيق بالعادات

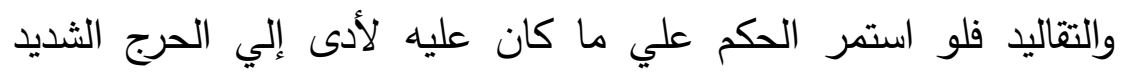

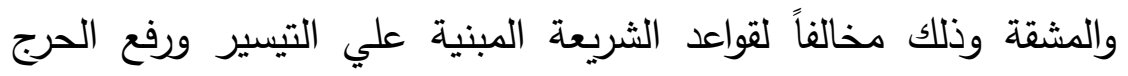

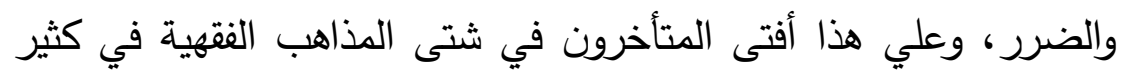

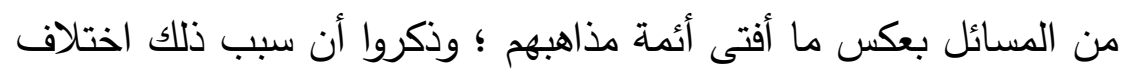

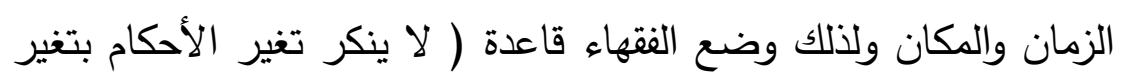
(الأزمان (الزمان وان (؟)

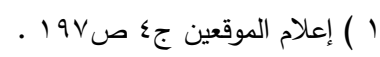

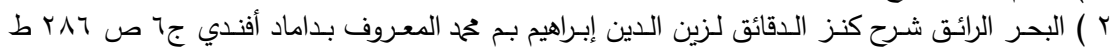

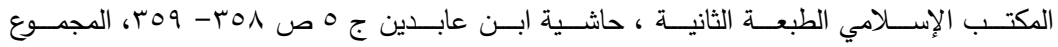

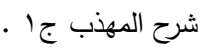

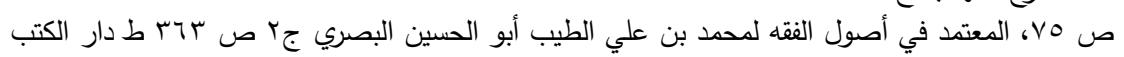

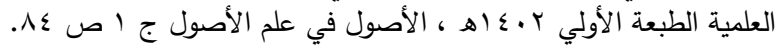

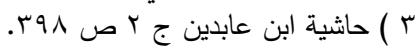

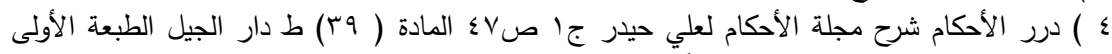

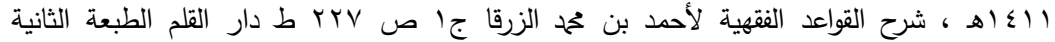
9 


\section{المبحث الثالث ( أسباب شذوذ الفتوى )}

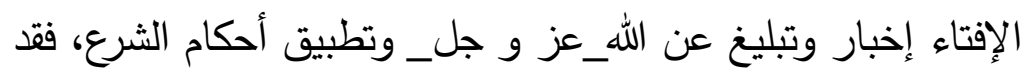

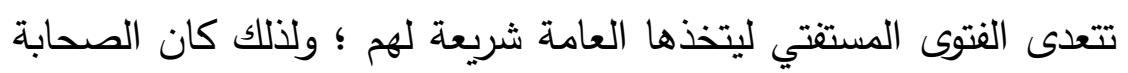

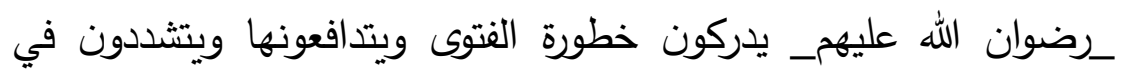
التساهل فيها ويدل على ذلك :

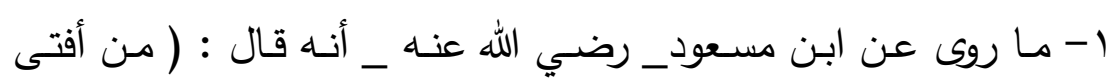

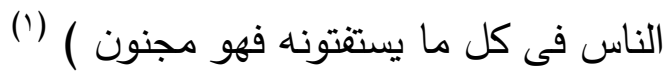
r- ما روي عن أبى حصين الأسدي (r) أنه قال : ( إن أحدكم ليفتي في الني

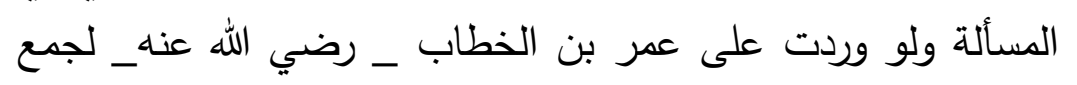

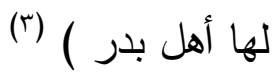
r- ما روي عن عبدالرحمن بن أبي ليلي قال : (أدركت عشرين ومائة

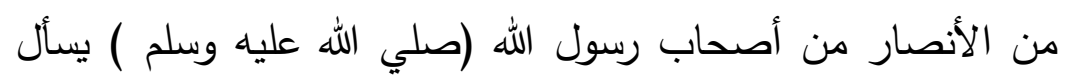

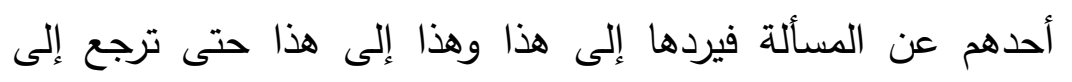

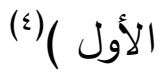

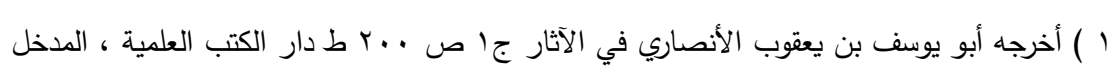

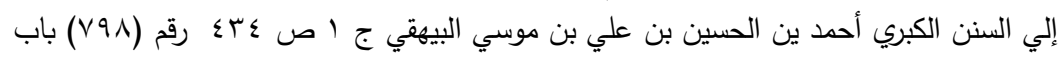

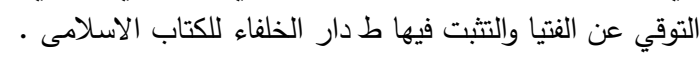

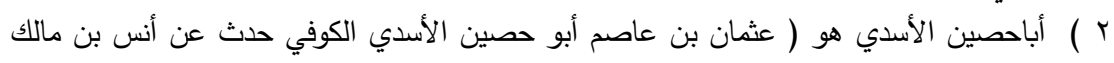

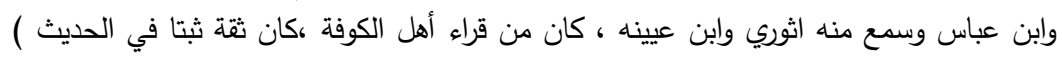

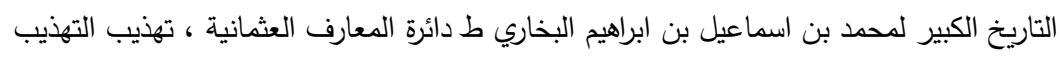

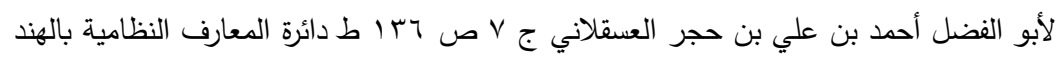

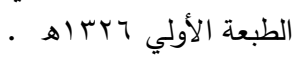

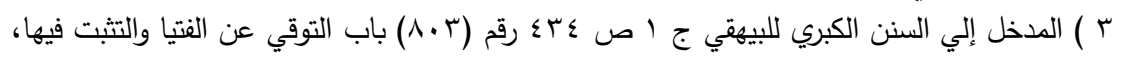

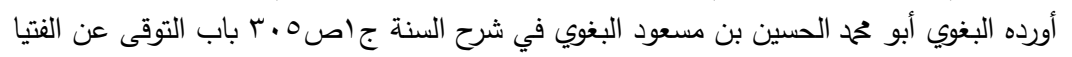

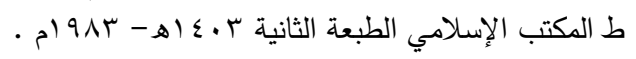

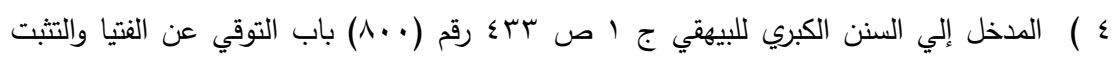


وجه دلالة الآثار : - مجار

في الآثار دليل علي أن الصحابة كانوا يتهيبون الفتوي ويتريثون في أمرها وربما يتوقفون في بعض الأحيان عن القول فيها علي الرغم مما أتو دان

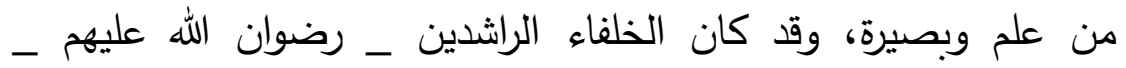
يجمعون علماء الصحابة وفضلاءهم عندما تعرض لهم بعض المسائل

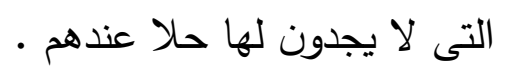

وإذا كان هذا هو حال الصحابة _ رضوان الله عليهم _فـما بال أقوام من الأمة يتصدرون للافتاء بغير علم متساهلين مضللين ومضلين فجاءت هوات فتواهم شاذة غير مقبولة .

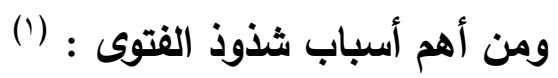

1- صدورها من غير المختصين بعلوم الشربعة الإسلامية الذين ورثوا

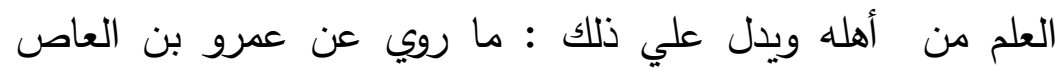

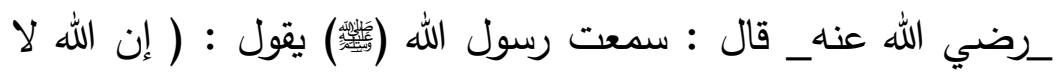
يقبض العلم انتزاعا ينتزعه من العباد، ولكن يقبض العلم بقبض لهن

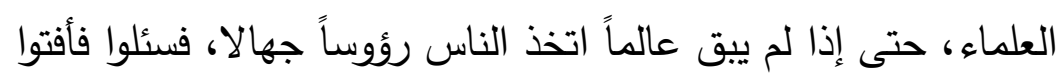

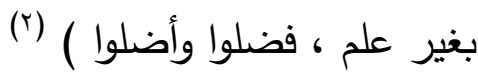

( ) تبصرة الحكام في أصول الأقضية ومناهج الأحكام لإبراهيم بن علي برهان الدين بن فرحون

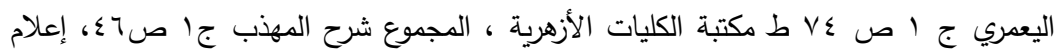

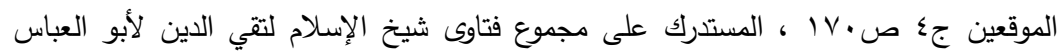

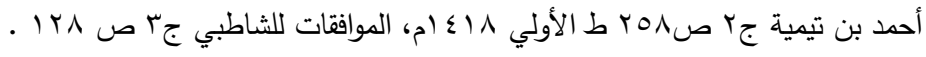

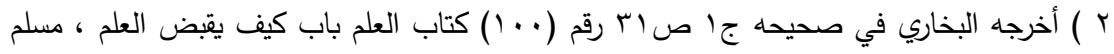

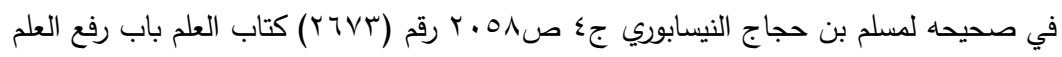
وقبضه وظهور الجهل ط دار إحياء التراث العربي . 


\section{وجه دلالة الحديث :}

في الحديث دليل علي التحذير الثديد من الجراءة علي الفتوي بغير علم؛ لما فيه من اضلال الناس، فالمفتي الجاهل يتحمل وزر من أضله ،

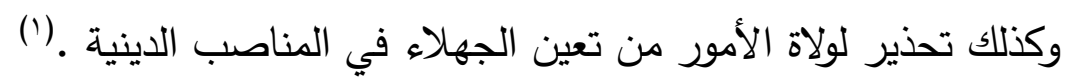
r- ضعف الملكة الأصولية ، وقلة الاطلاع على كتب أصول الفقه وندرة الممارسة لقواعده ، فمن المعلوم أن علم أصول الفقه هو الأساس الاس ولى الذي يبنى عليه علم معرفه الحلال والحرام • r- الفهم الخاطئ للنصوص ، وعدم معرفة المفتي في بعض الأحيان بألفاظ وكلمات المستفتي للاختلاف في اللهجة والأعراف والعادات فيؤدي إلى عدم تصور المسألة المسئول عنها فتأتي الإجابة على غير الحقيقة فيخطئ في جوابه ويدل على ذلك قول النووي : ( لإئ يجوز أن يفتي في الأيمان والإقرار ونحوهما مما يتعلق بالألفاظ إلا أن

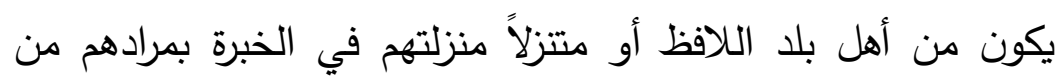

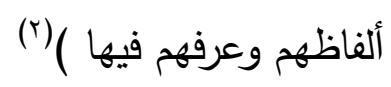

ع- تبنى الأراء الشاذة والأقوال الضعيفة التي وجدت لها مريديها من العامة الذين زينت لهم أنفهه زخرفها فتقبلوها ودافعوا عنها بدعوى والعى أنها صادرة من علماء اجتهدوا في فهم الواقع المعاصر وحاجات - المسلم

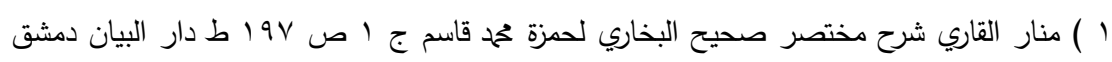

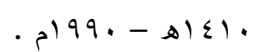

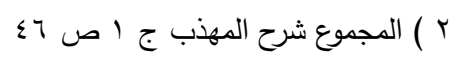


0- التساهل في الفتوى يكون بتتبع الرخص والثبه والحيل المكروه

(1) (1)

ويكون الاحتيال حراما إذا تسبب في اسقاط ما وجب علي المكلف فعله كمن كان لله مال يقدر به علي الحج فوهبه كى لا يحج ، أويكون التساهل في طلب الأدلة فيأخذ بمبادئ النظر وأوائل الفكر، أو يعمل بالأهواء والرغبات، فعلى من يتعرض للإفتاء أن يدرك مقاصد الشرع ومصالح

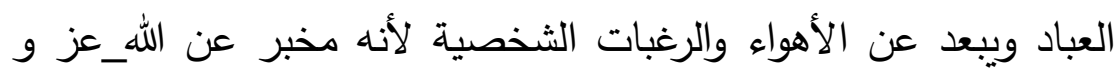
جل_فمن أفتى بهواه موافقه لغرضه أو غرض من يحابيه يكون مفتريا على الله ويدل على ذلك قوله تعالى :

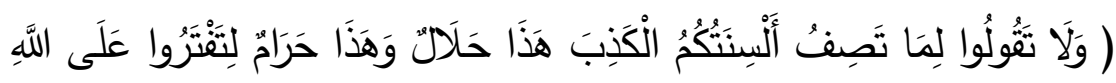

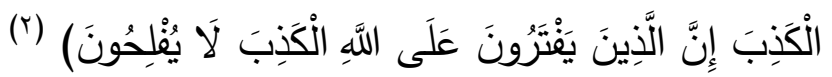

( ) ويدل على ذلك ما جاء في البحر الرائق ما نصه : (ويحرم التساهل في الفتوى وإتباع الحيل إن

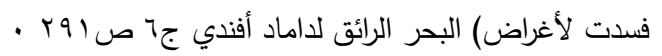

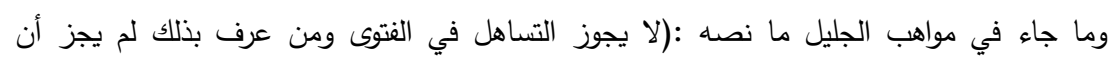
يستقتي ) مواهب الجليل شرح مختصر خليل لشمس الدين أبو عبد الله محمد عبد الرحمن الطرابلسي

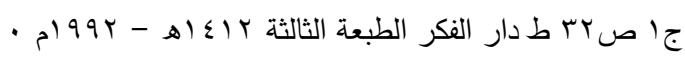
وما جاء في أسنى المطالب ما نصه : (يحرم التساهل في الفتوى ويحرم اتباع الحيل المحرمة مطلقاً)

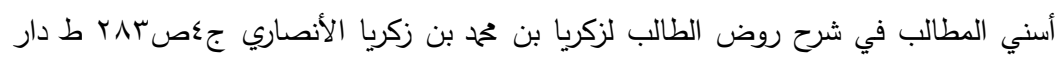

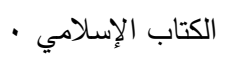
ما جاء في مطالب أولى النهى ما نصه : ( لا يجوز للمفتي ولا لغيره تتبع الحيل المحرمة والمكروهة

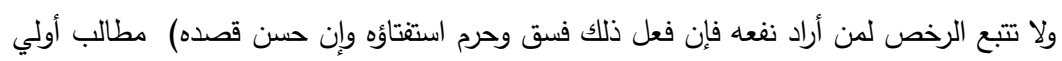

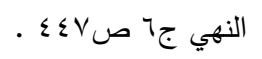
r ( ) سورة النحل آية رقم (1) (1). 
وجه دلالة الآية :

نهـى سـبحانه وتعـالى عـن التحـريم والتحليـل بـالأهواء والرغبـات

أو برأيه وتشهيه دون مستتد شرعى • (')

وقول ابن القيم في إعلام الموقعين ما نصه : ( فلا يجوز العمل والإفتاء في دين الله بالتشهي والتخير وموافقة الغرض فيطلب القول الذي يوافق غرضسه وغرض من يحابيه فيعمل به، ويفتي به، ويحكم به، ويحكم

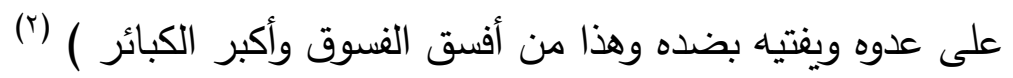

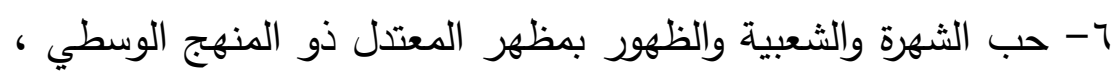
فقد يكون المقصد صحيحاً في نفسه ولكن لا يبيح له التحريف في

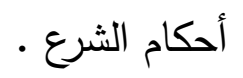

- التسرع وعدم التأني في إصدار الفتاوى وربما حمله علي ذلك توهمه أن السرعة براعة وإثبات القدرة على الإفتاء والتروي عجز فعلى المفتي أن لا يتسرع في الحكم على المسألة قبل استيفاء حقها من النظر والفكر إلا إذا تقدمت معرفته بالمسئول عنه فلا بأس بالمبادرة . ^- انفتاح بعض الدعاة والخطباء على حضارة الغرب التي تبهر العقول وقد كانوا قبل ذلك في بيئة منغلقة فلما انفتحوا على غير بيئته الأصلية أفضى بهم إلى نوع من التحلل والانسلاخ من القيود وصاروا يفتتون بالغرب تأصيلا وتفريعاً مما دفعهم إلى صدور بعض الفئ الفتاوى

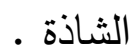

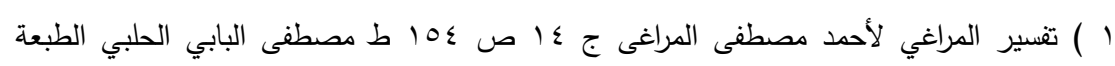

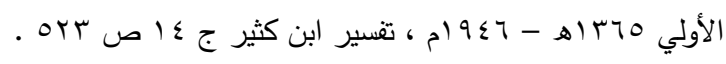

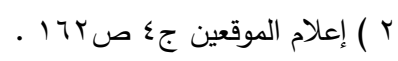


9- عدم إدرالك خطر الفتوى وعظمها والنتائج المترتبة على عدم صحتها ويدل على ذلك قول ابن حمدان ما نصه: (عظم أمر الفتوى وخطرها وقل أهلها ومن يخاف إثمها وخطرها وأقدم عليها الحمقى والجهال ورضوا فيها بالقيل والقال واغتروا بالامهال والاهمال واكتقوا بزعمهم

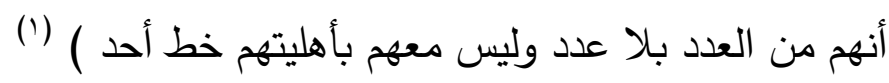

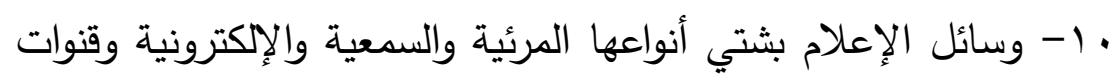
الإثارة الإعلامية ولا ينكر أحد الدور الإيجابي للقنوات الملتزمة المقدرة لعظم الأمانة والمسئولية الملقاة على عاتقها وربما دون قصد يُسأل لئل الإئل العالم في مسألة لا يتعرف على حيثياتها من المستفتي فيجيب إجابة عامة مما يسبب فوضى شرعية قد لا يتفطن لها العالم ولا القائمون على هذه القنوات ولذلك قلنا لابد من التثبت من السؤال والاستقصال

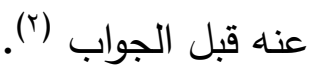

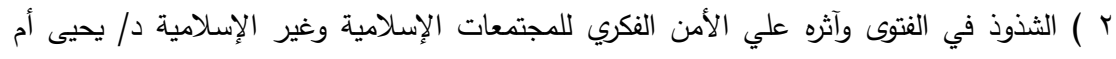

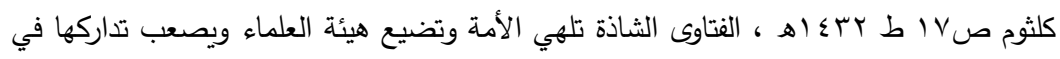

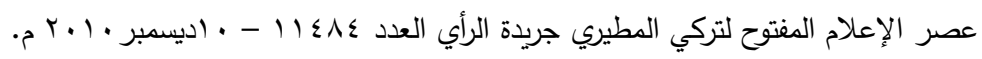




\section{المبحث الرابع ( معايير وصف الفتوى بـالشذوذ )}

لا يُنكر وجود خلاف بين الفقهاء في مسائل الفقه الفرعية بشرط عدم المساس بالأصول والثوابت ، فلا ينكر تغير الأحكام بتغير الأزمان

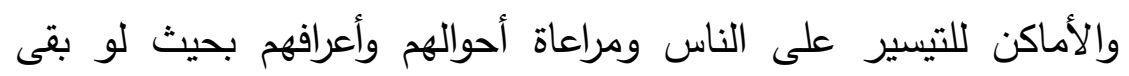
الحكم على ما كان عليه لزم منه المشقة والضرر بالناس فهناك فتاوى أخذ

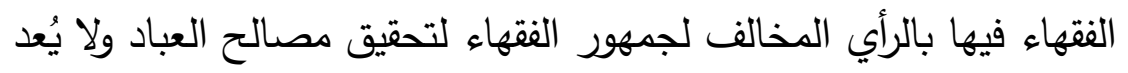
ذلك شذوذا في الفتوى كفتوى ابن تيمية وتلميذه ابن القيم حول له مسألة الطلاق (') ثلاثاً في مجلس واحد وقد خالفوا الجمهور فالمسالة فيها رأيان: الرأي الأول/ لجمهور الفقهاء من الحنفية والمالكية والثافعية والحنابلة في الراجح عندهم إلى أنها تطلق ثلاثا ولا تحل حتى تتكح زوجاً غيره . (r) الرأي الثاني / لمتاخري الحنابلة ابن تيمية وتلميذه ابن القيم إلى أنها تطلق واحدة رجعية . (r)

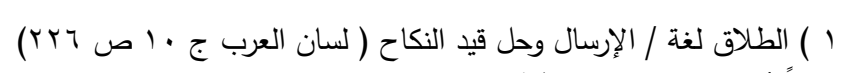

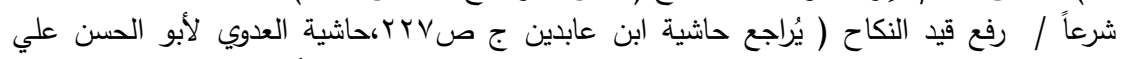

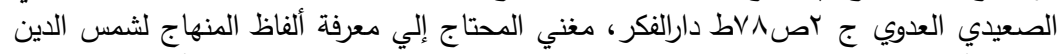

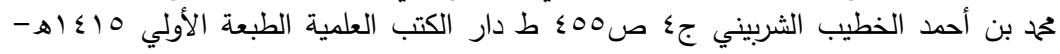

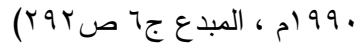

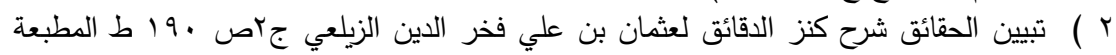

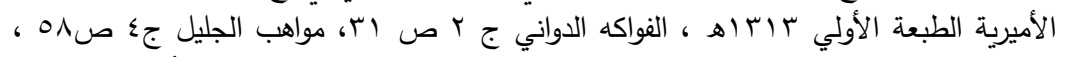

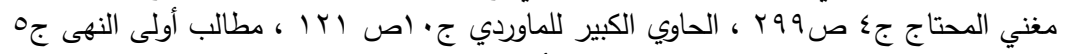

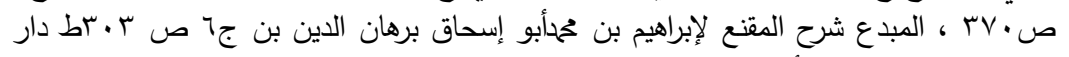

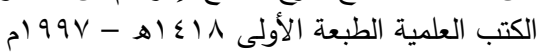

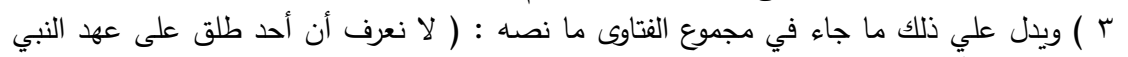

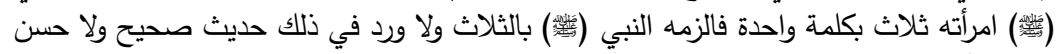

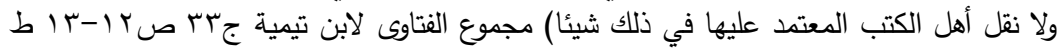

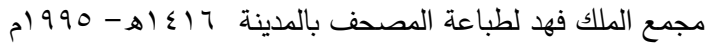

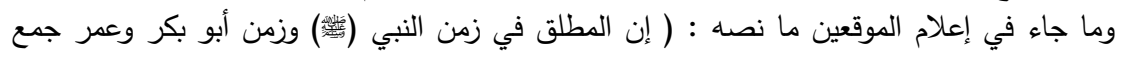

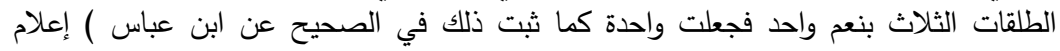

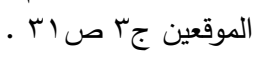


هل الحكم الذي جعله الشرع من البينونة للمطلقة ثلاثا يقع بالزام

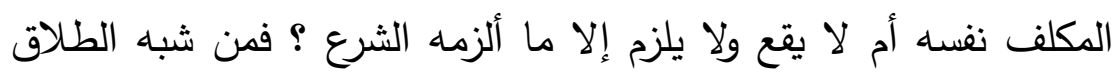

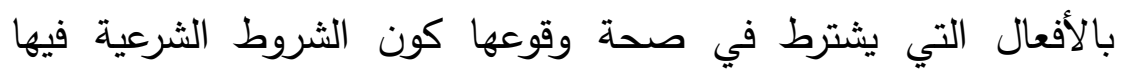

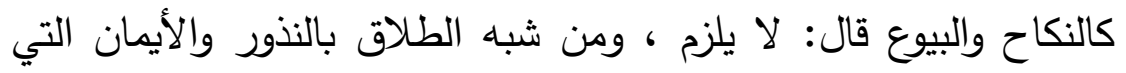

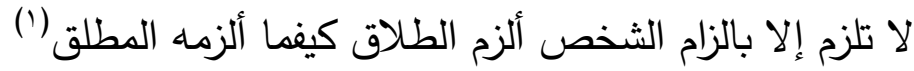
أدلة الرأي الأول

استدل الجمهور أصحاب الرأي الأول القائلين بأن طلاق الثلاث بلفظ واحد يقع ثلاثا بالقرآن الكريم والسنة النبوية والأثر والمعقول :

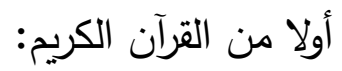

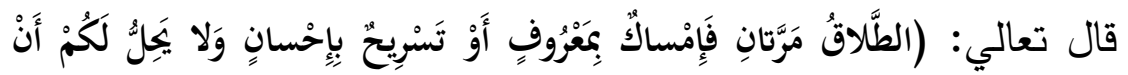

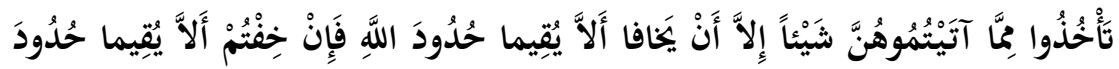

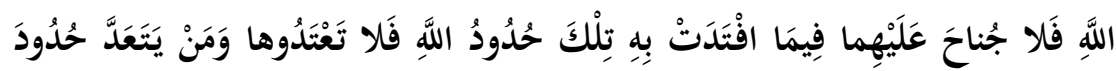

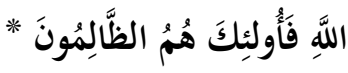

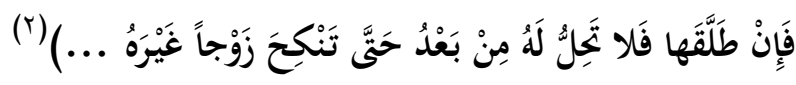
وجه الالالة من الآيات : من وجهين الوجه الأول / أن الآية دليل علي جواز طلاق الثلاث بلفظ واحد وأن مالن الته التعديد إنما هو فسحة لهم فمن ضيق علي نفسه لزمه (r).

1 ) بداية المجته ونهاية المقتصد لأبو الوليد محمد بن أحمد بن رشد القرطبي جr صع^ ط دار

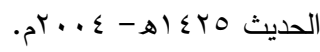

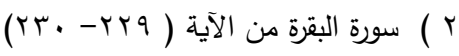

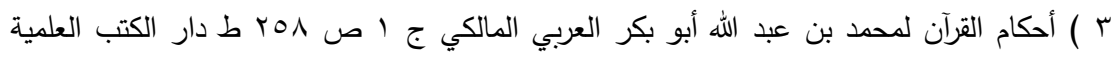
• 
الوجه الثاني / أن المقصود من الآية بيان عدد الطلاق أنه ثلاث ويملك

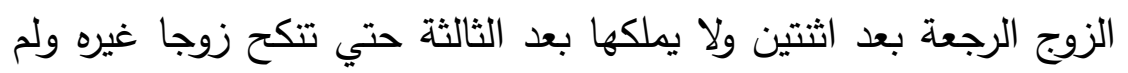

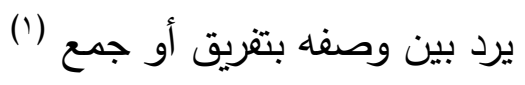

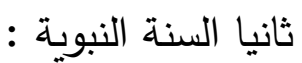
ماروى عن عائثة رض الله عنها أن رجلا طلق امرأته ثلاثا فتزوجت

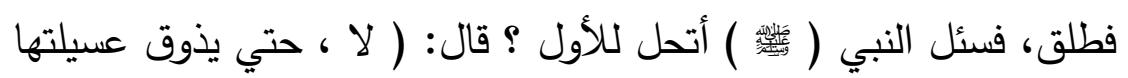

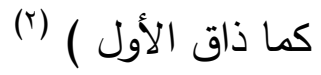

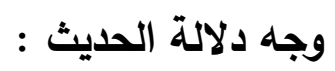

في الحديث دليل علي أن الرجل إذا طلق امرأته ثلاثا مجتمعة في

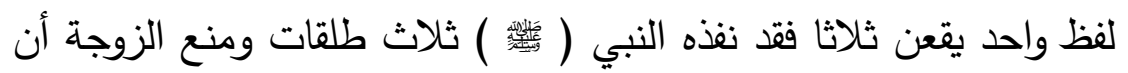

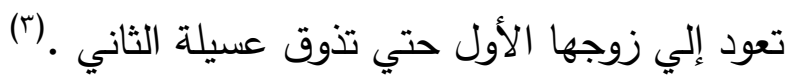

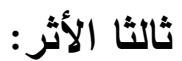
1- ماروى عن مجاهد قال كنت عند ابن عباس فجاءه رجل فقال: ( إنه

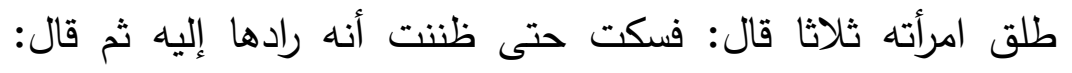

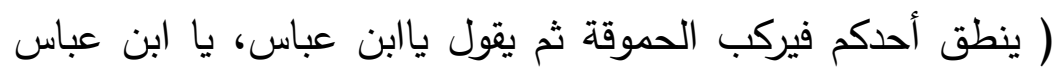

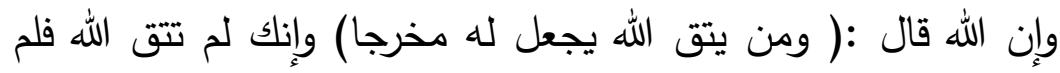

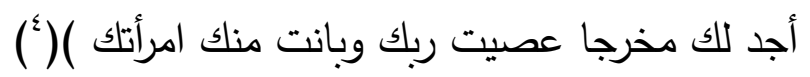

1 ) الحاوي الكبير للماوردي ج · (1 ص سبا.

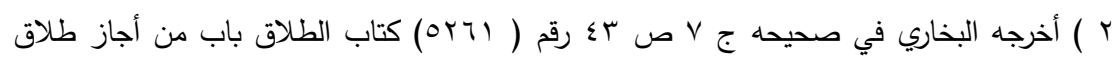
الثلاث اخدجه

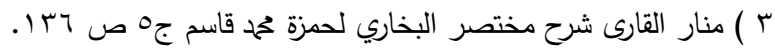

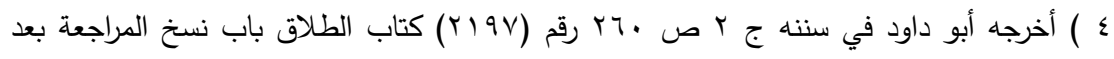

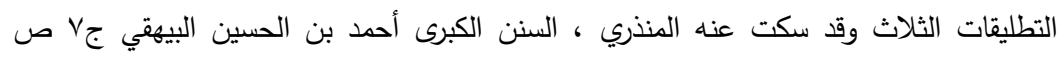

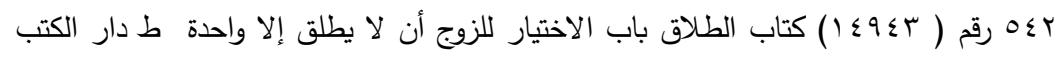

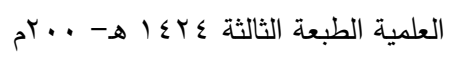




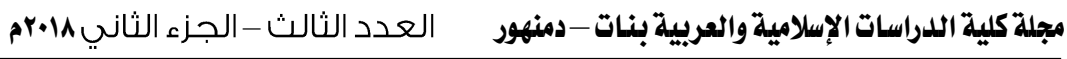

r- مارواه مالك في الموطأ أن رجلا جاء إلى عبد الله بن مسعود فقال :

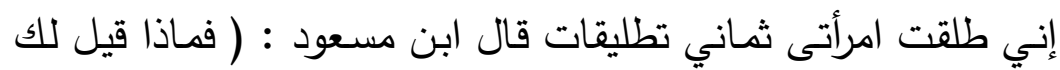
قال : قيل أنها قد بانت منى فقال ابن مسعود :صدقوا ، من طلق كما

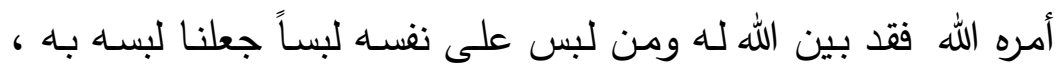

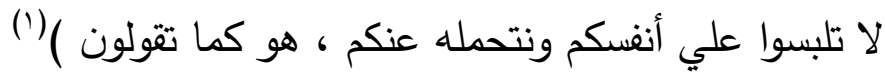
وجه الالالة من الأثرين :

في الأثرين دلالة علي أن طلاق الثلاث بلفظة واحدة يقع ثلاثا (r) رابعا المعقول : من وجهين الوجه الأول / أن النكاح ملك يصح إزالته متفرقا فصح مجتمعا كسائر

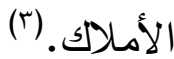

الوجه الثاني / أن الطلاق أوقعه من يملكه فوجب أن يلزمه ـ(ء) أدلة الرأي الثاني استدل أصحاب الرأي الثاني القائلين بأن طلاق الثلاث بلفظ واحد تقع طلقة واحدة بالقرآن الكريم والسنة النبوية والقياس :

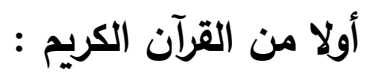

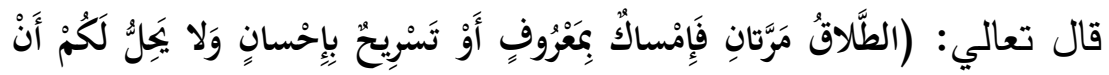

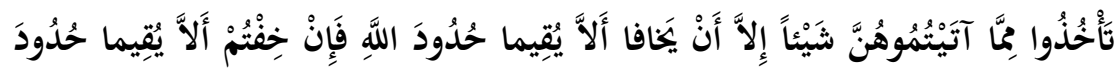

( ) أخرجه مالك بن أنس الأصبحي في الموطأ جع ص VA9 رقم ( Y.r.r) باب ما جاء في البتة ط الدكتبة التوفيقية.

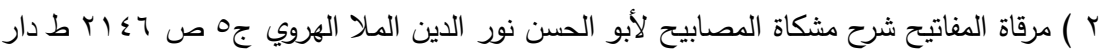

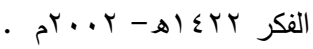

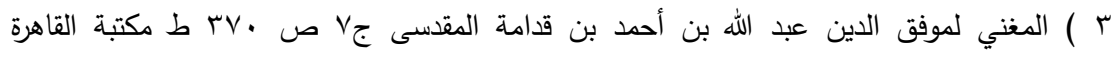
.

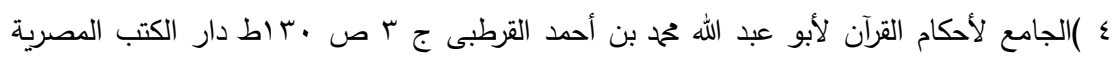

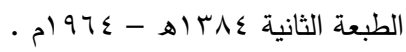




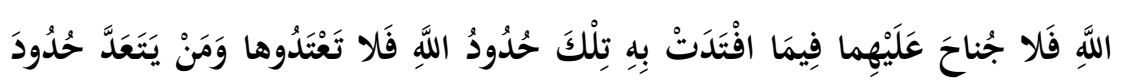

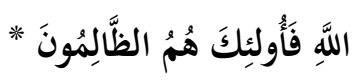

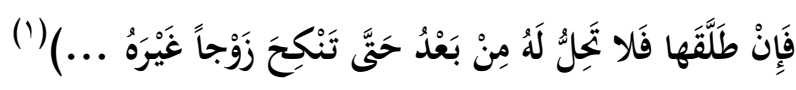

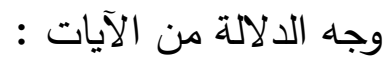

في الآيات دليل علي أت التطليق الشرعي يجب أن النيات يكون تطليقة بعد

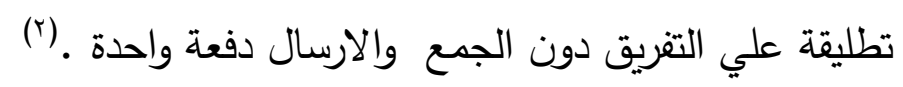
ثانيا من السنة النبوية :

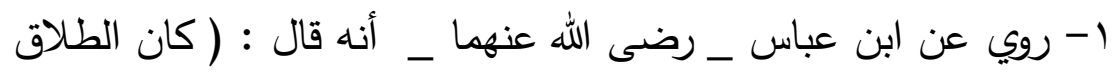

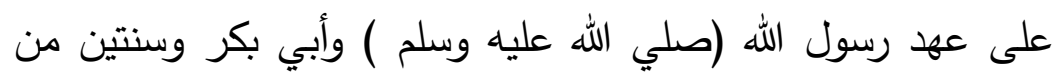

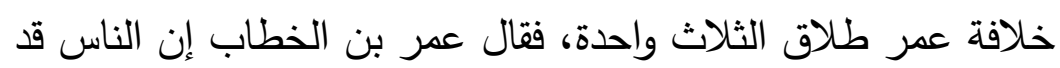
استعجلوا في أمر قد كانت لهم فيه أناه فلو أمضيناه عليهم فأمضاه

(r) عليهم )

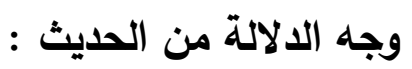

في الحديث دليل واضـح علي أن الطلاق الثلاث بلفظ واحد يقع التح طلقة واحدة وإنما أمضاه عليهم عمر ثلاثا؛ لما رأى الناس استهانوا بأمر الطي

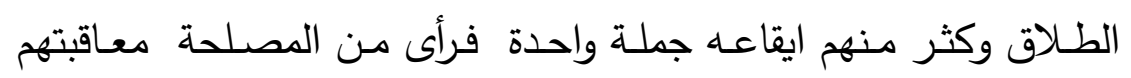

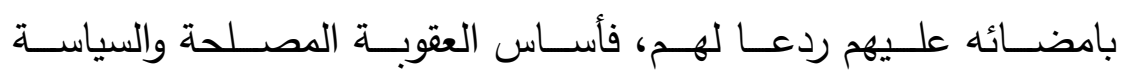

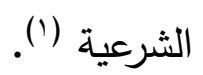

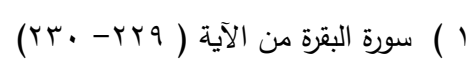

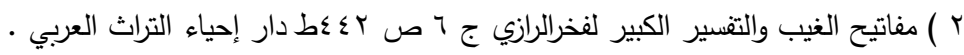

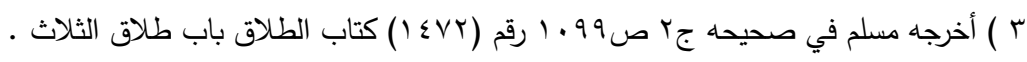

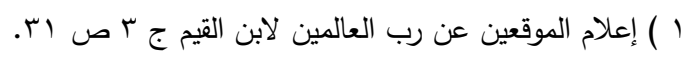


r- ما روي عن ابن عباس قال : ( طلق ركانة بن عبد يزيد امرأته ثلاثا

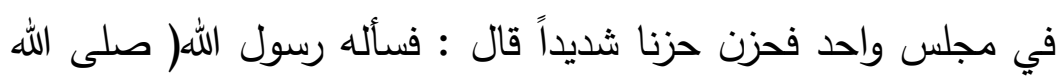

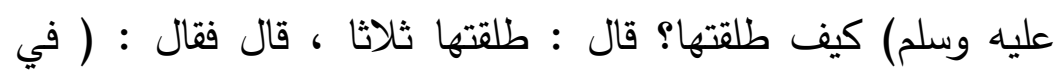

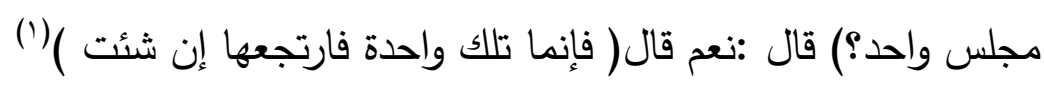
وجه الدلالة من الحديث : في الحديث دليل لا يقبل التأويل أن طلاق الثثلاث في مجلس واحد يقع واحدة . ثُالثا القياس:

أن جمع الثلاث محرم وبدعة فلا يقع لأنه منهى عنه والنهي

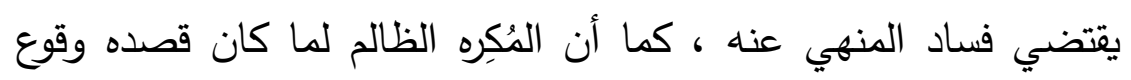

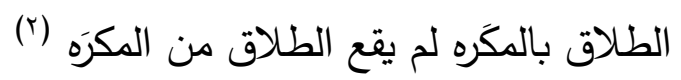
المناقشة :

ناقش الجمهور أدلة الزأي الثاني بما يلى :

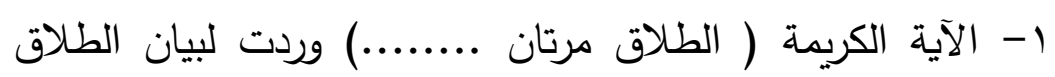

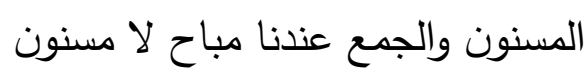

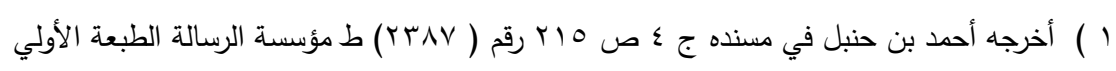

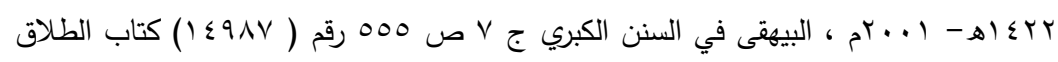

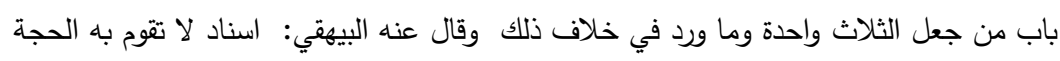

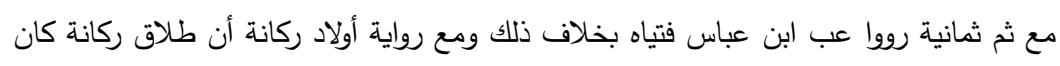
واحدة . تمان

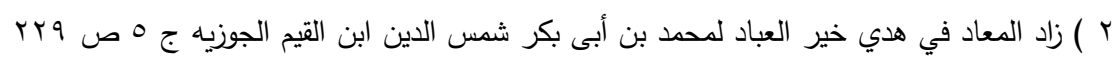

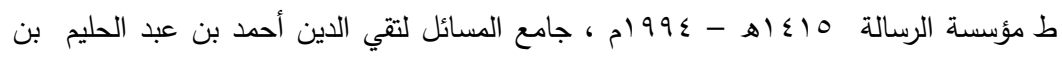

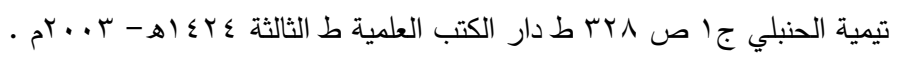


بأنه ليس في الآية بيان صفة السنة بل كان تفسيراً للأصل في الطلاق وإن كان بلفظ الخبر إلا أن معناه الأمر أي: طلقوا مرتين أي

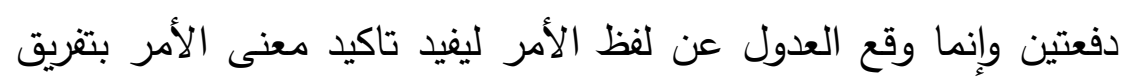

(الطلاق (1)

r- حديث ابن عباس ( كان الطلاق علي عهد .....) يجاب عليه من

$$
\text { عدة وجوه : (لمان }
$$

الوجه الأول/ أن الحكم كان كذلك ثم نسخ في عصر النبي( إلا أنه لم يشتهر النسخ فبقى الحكم المنسوخ معمولا به إلي أن أنكره عمر (r) الوجه الثاني / بأن حديث ابن عباس الواقع في الصحيح إنما رواه عنه من أصحابه طاوس وأن جّل أصحابه رووا عنه لزوم الثخلاث ومنهم سعيد بن جبير ومجاهد وعطاء وعمرو بن دينار فالحديث مختلف في صحته فلا يقدم على الإجماع ، فلا يسوغ لابن عباس أن يروي ذلك ويفتي

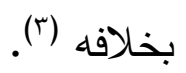

الوجه الثالث / يحتمل أن يكون محمول علي صورة تكرير الطلاق ثلاثا

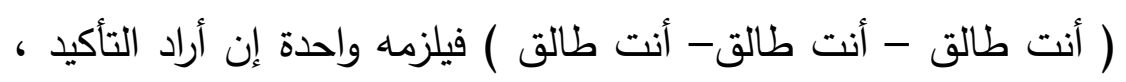
وثلاثا إن أراد الاستئناف فقد كان الناس في عهد الرسول وأبي بكر

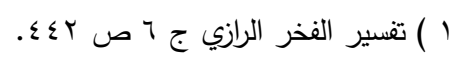

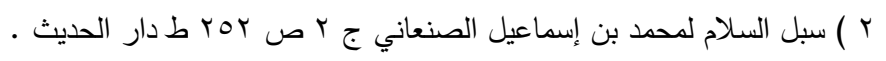

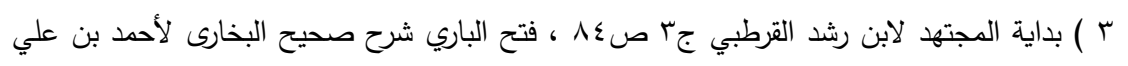

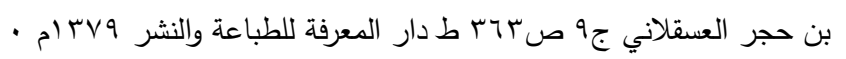


يصدقون في دعوى التأكيد لما كانوا عليه من خشية الله ، ولما رأي عمر تغير الأحوال عند الناس أوقعه ثلاثا علي إرادة الاستئناف ولم يقبل دعوى التأكيد وقد أشار إليه بقوله ( إن الناس قد استعجلوا في أمر كانت لهح فيه

(') (أناة )

\section{وأجيب علي ذلك :}

بأن مخالفة عمر لما مضى لا شيئ فيها ؛ لأنها ترجع إلي تغيير الحكم بسبب تغير العرف وحال الناس ، فرأى عمر مصلحة في زمانه ووافقته

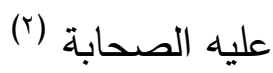

ب- حديث ابن عباس عن ركانة يجاب عليه : أنه حديث مضطرب لأنه جاء في رواية أنه طلقها البتة وقال أبو داود هذا أصح من أن ركانة طلقها ثلاثا ، فيبقى الحديث ضعيفاً من حيث المتن فيكون خارج محل

$$
\text { وأجيب علي ذلك : النزاع •(r) }
$$

بأن أئمة الحديث العارفون بعلل الحديث كأحمد بن حنبل قد صحح اسناد حديث ركانة في طلاق امرأته ثلاثا في مجلس واحد وحسنه (ء) بعل

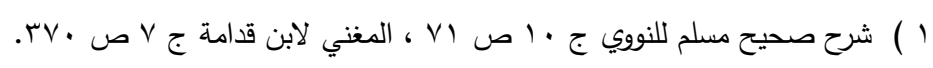

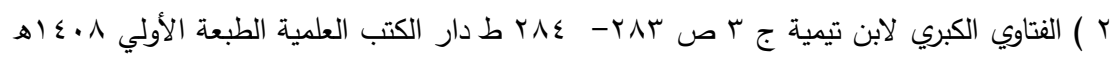

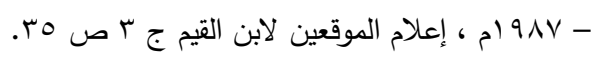

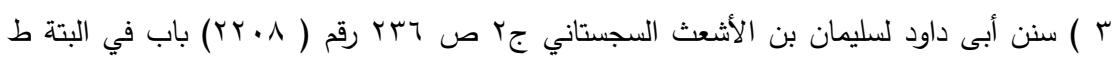

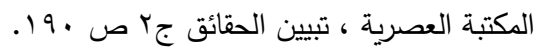

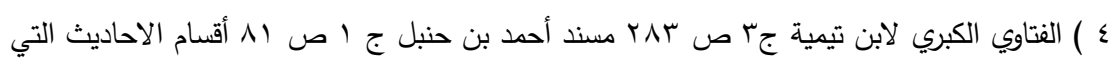
في المسند . المتاوي لاكيري 
ناقش أصحاب الرأي الثاني أدلة الجمهور بما يلي :

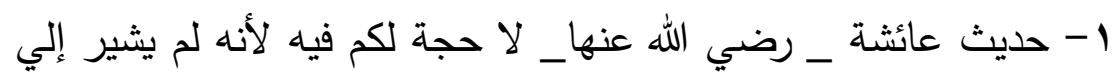

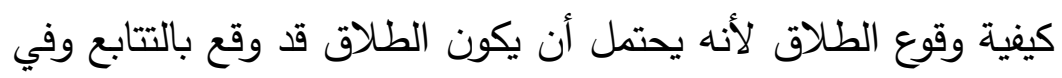

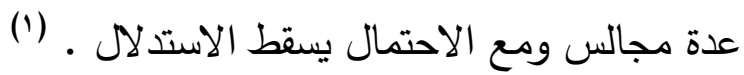

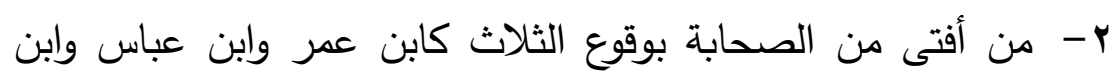

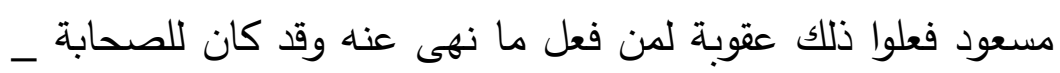

رضوان الله عنهم_ اجتهادات في أنواع العقوبات (†). الرأي الراجح : ما ذهب إليه متأخرو الحنابلة : بأن طلاق الثثلاث في مجلس واحد

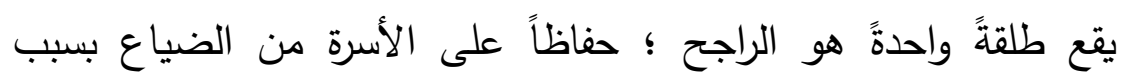

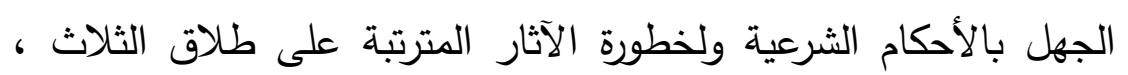

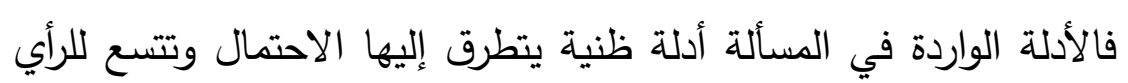

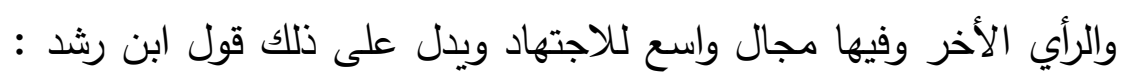

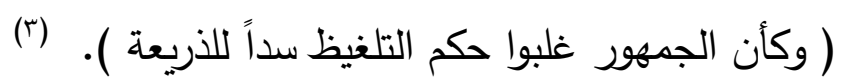

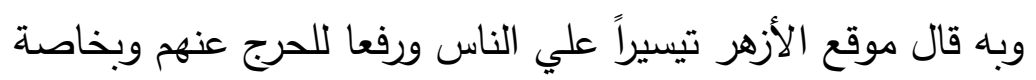

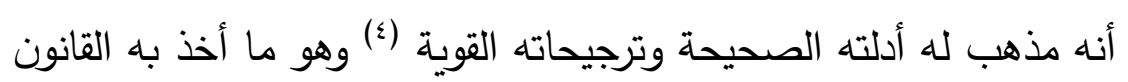

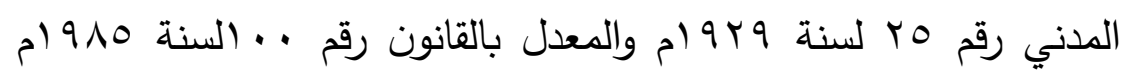

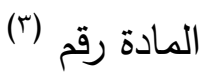

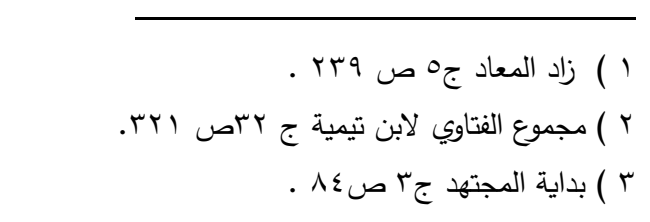
www. Azhar. egKwww. Alifta. net ( $\varepsilon$ 


$$
\text { (( الطلاق المقترن بعدد لفظاً أو إثارة لا تقع إلا واحدة )). }
$$

فلا يُعد الرجوع عن القول بتطليقها ثلاث إلى أنها تطلق واحدة قولاً شاذاً ولا ينكر على المفتي القول به وإنما ينكر عليه تتبع الأقوال الثاذة

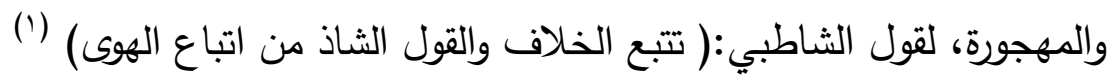
كما ننكر جعل الخلاف سباً في إصدار فتاوى شاذة تتسب إلى الدين وهي ليست منه في شىء فلابد من تتبع المنهج الإسلامي الوسطي من غير إفراط ولا تفريط

\section{(r): ولذلك وضع العلماء معايير لوصف الفتوى بالثذوذوني} المعيار الأول : أن تعارض الفتوى نصا صريحاً من القرآن أو السنة فالأحكام الفقهية الثابتة بالأدلة القطعية تمثل الثوابت والأصول التي لا تتغير بتغير الزمان والمكان أو الأحوال فلا مجال فيها للاجتهاد أو التجديد ، وإنما يكون التجديد في الوسائل والآليات التي تخدمها وتبرزها، فادعاء التجديد فيما لا يقبل التجديد شذوذٌ في الفتوى ويدل على ولى ذلك ما جاء في درر الأحكام ما نصه : ( إن الأحكام التي تتغير بتغير الأزمان هي الأحكام المستتدة على العرف والعادة ؛ لأنه بتغير الأزمان تتغير احتياجات الناس ، وبناء على هذا التغير يتبدل أيضا العرف والعادة وبتغير العرف والعادة تتغير الأحكام حسبما أوضحنا آنفا ، بخلاف ولئ

1 ) المدخل المفصل لمذهب الإمام أحمد بن حنبل لبكر بن عبد الله أبو زيد بن محمد بن عبد الله بن بكر

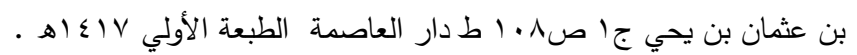

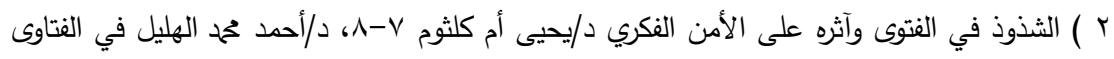

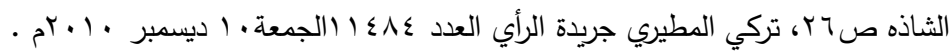


الأحكام المستندة على الأدلة الثرعية التي لم تبن على العرف والعادة

فإنها لا تتغير ) (')

ومثال الثذوذ في الفتوى لتعارضها مع النص الصريح :

ا- إباحة لحم الخنزير في البلاد الباردة مع وجود نص صريح

\section{بتحريمها}

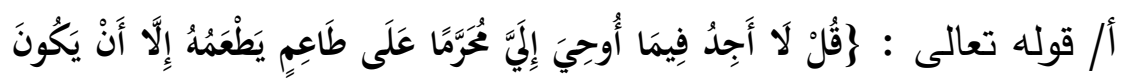

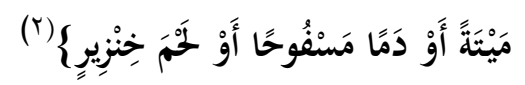

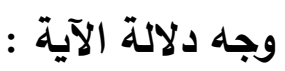

في الآية دليل قطعي علي تحريم لحم الخنزير؛ فقد أمر الله تعالى رسوله بأن يخبرهم بأنه لا يجد فيما أوحاه الله إليه محرم إلا ما ذكر في الآية وعد

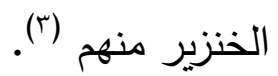

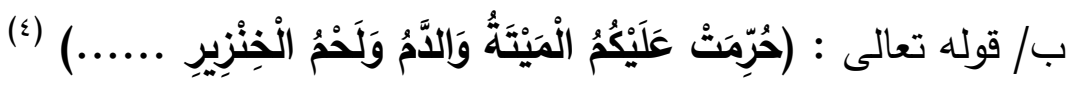

وجه دلالة الآية :

في الآية دليل علي تحريم لحم الخنزير حيث وصفه سبحانه وتعالى بأنه رجس أي : نجساً؛ لتغذيه علي القاذورات فالنجاسة علة التحريم ذكى أو لم يذلكِ ولكونه يحمل الكثير من الأمراض التي ينقلها للإنسان .(o) فقد ذكر الرازي عن أهل العلم ( الغذاء يصير جزءاً من جوهر المتغذى لاهنى فلابد أن يحصل للمتغذي أخلاق وصفات ما كان حاصلاً في الغذاء

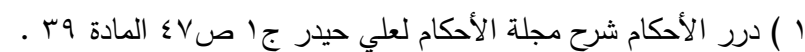

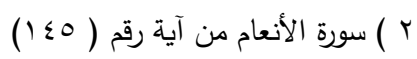

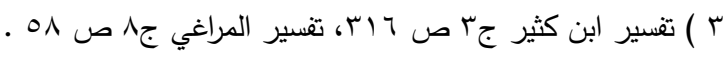

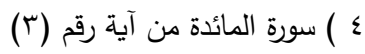

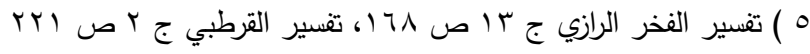


والخنزير مطبوع علي حرص عظيم وررغبة شديدة في المشتهيات فحرم

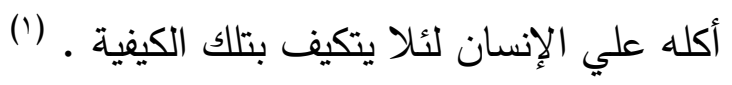
فالتحريم لم يأت عبثاً وإنما جاء ليحقق مقصد من مقاصد الشريعة

الإسلامية وهي الحفاظ علي النفس المأمور بحفظها (r) r- المساواة بين الرجل والمرأة في الميراث مع وجود نص صريح بعدم

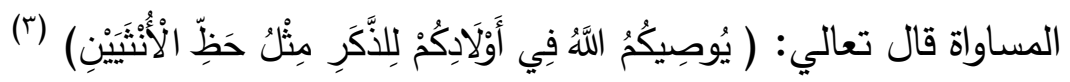
وجه دلالة الآية :

الميراث نظام دقيق محدد من الثارع تبارك وتعالى لم يترك لاجتهاد

المجتهدين بل حدده سبحانه وتعالى وفي الآية جعل للذكر مثل نصيب اثنتين من الإناث إن كانوا ذكورا وإناثاً وذلك نظراً إلي أن الواجبات

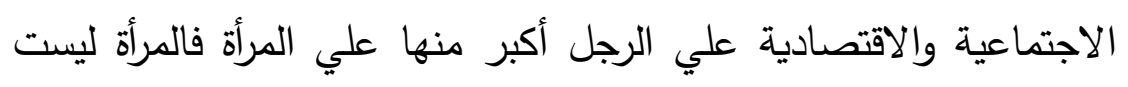
مكلفة بالانفاق علي نفسها أو بيتها أو أولادها حتي لو كانت غنية أو عاملة ولا تدفع مهراً عند زواجها وإنما المكلف بذلك كله هو الرجل فالإسلام لم يظلم المرأة عندما أعطاها نصف الرجل بل حباها وحماها(ء) . المعيار الثاني : أن تصدر الفتوى مدن ليس أهلاً للإفتاء ، ولذلك لابد من اعتبار الشروط الواجب توافرها في المفتي (ْ). المعيار الثالث : ألا تراعى الفتوى تغير المكان والزمان وأحوال الناس ، فالأصـل في الشـريعة الإسـاليمة التيسير ورفع الحرج عن النـاس ، فـإذا

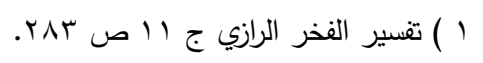

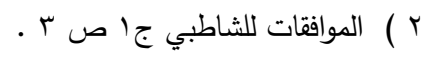

$$
\begin{aligned}
& \text { (ب ) سورة النساء من آية رقم (11) }
\end{aligned}
$$

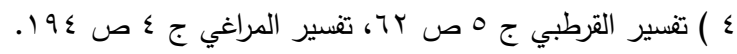

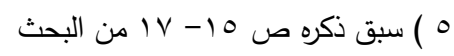


لم تراع الفتوى أحوال الناس لأدى إلى الحرج والضرر ، وهو مرفوع بقوله

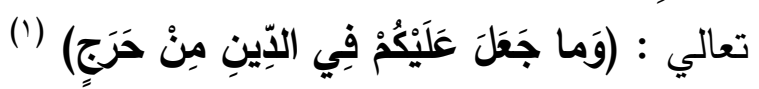

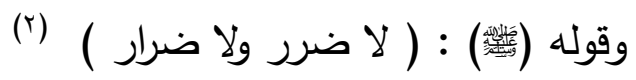
المعيار الرابع : أن يكون مستتد الفتوى أمراً متوهماً أو مالا يصلح دليلاً

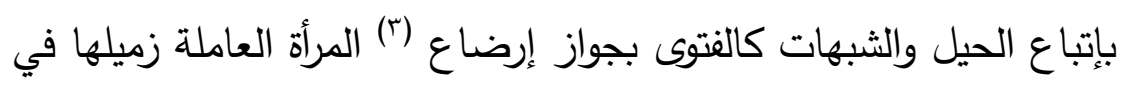

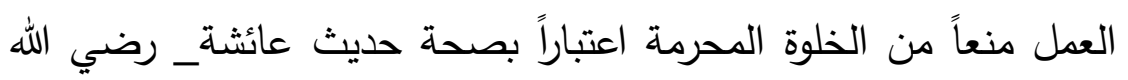

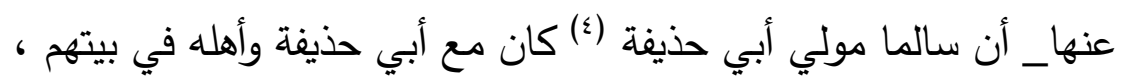

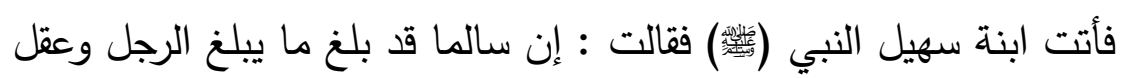
ما عقلوا وإنه يدخل علينا وإنى أظن أن في نفس أبي حذيفة من ذلك شيئًا

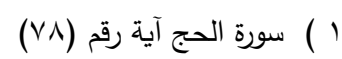

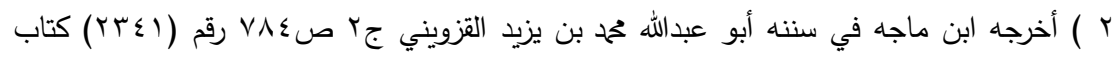

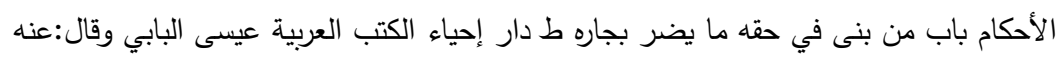

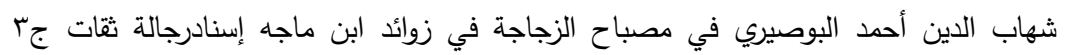

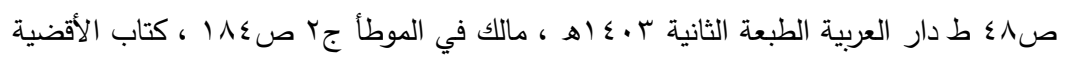

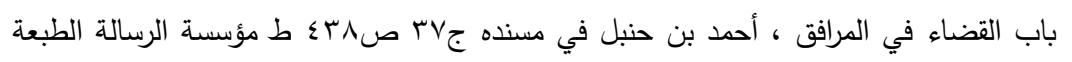

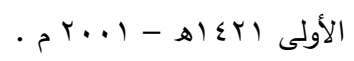

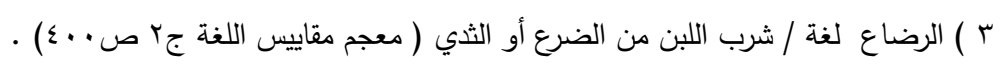

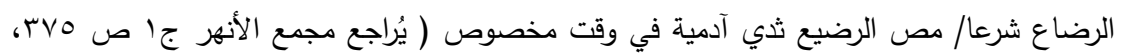

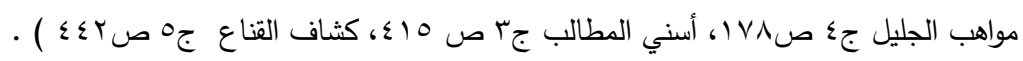
ء ) سالم مولى أبي حذيفة هو (سالم مولي أبى حذيفة بن عتبة بن ربيعة كان من أهل فارس أعتقته

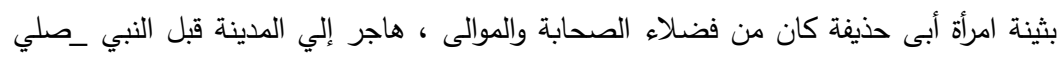

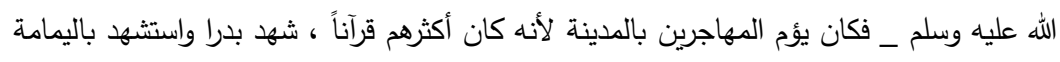

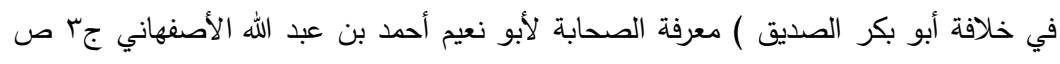

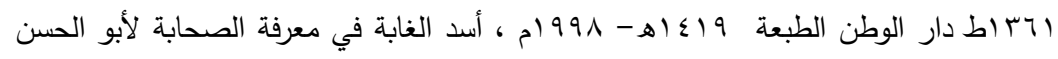

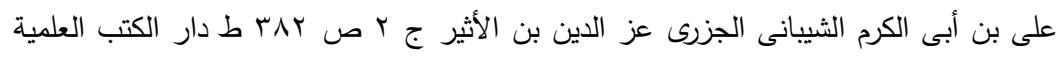

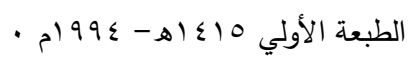


فقال لها النبي (酐) : (أرضعيه تحرمي عليه ويذهب الذي في نفس أبي

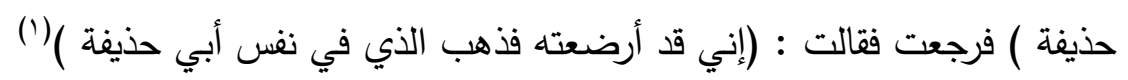

حمـل الحديث على الخصوصـية لسـالم مـولى أبـي حذيفـة بـليل

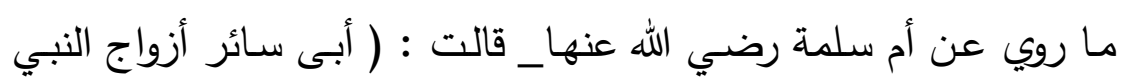

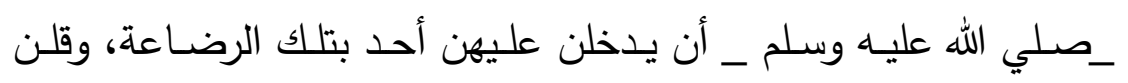

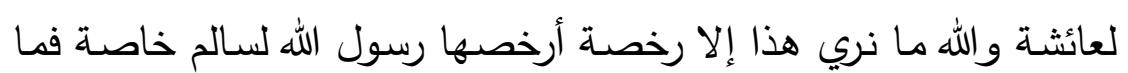

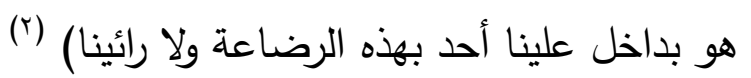
فلم يكن سالم بالنسبة لأبي حذيفة وأهله مجرد شخص أو حليناعة أوليف

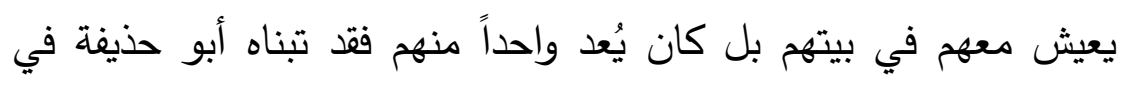

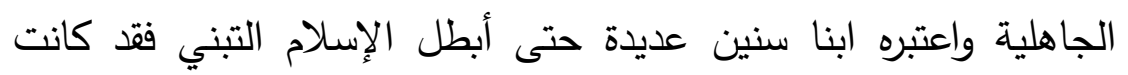

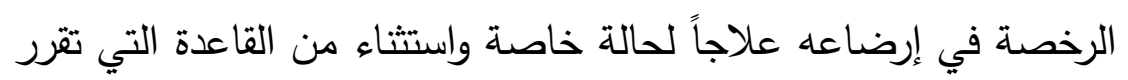

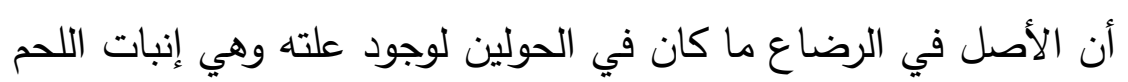

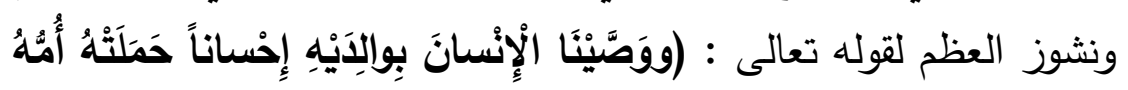

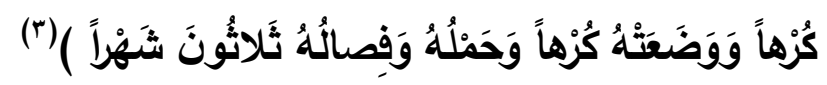

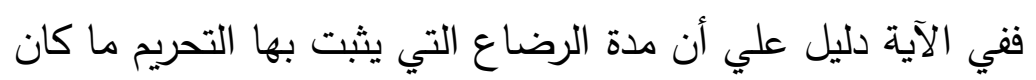

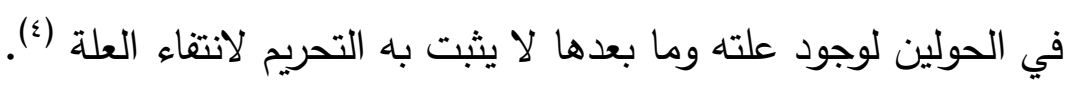

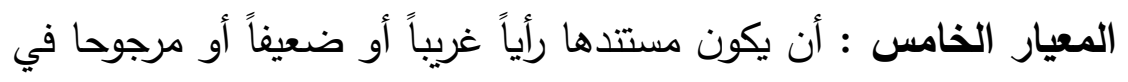

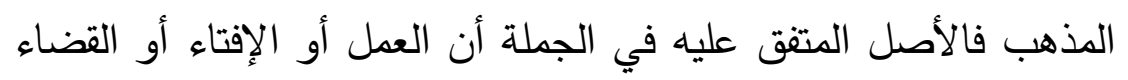

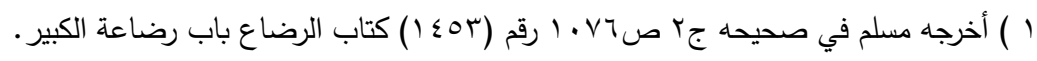

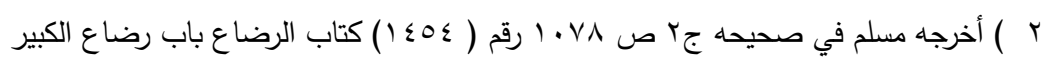

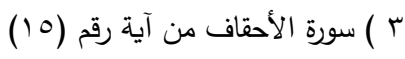

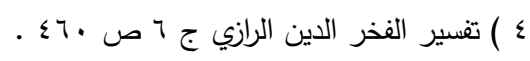


إنما يكون بالقول المشهور أو الراجح أو الصحيح في الدذهب دون القول

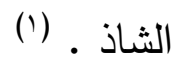

المعيار السادس : أن تخالف الفتوى مقاصد الثريعة من معايير وصف الفتوي بالثذوذ أن تخالف مقاصد الثرعية وما تسعى إلي تحقيقه من مصالح فالثريعة جاءت لتحقيق مصالح العباد

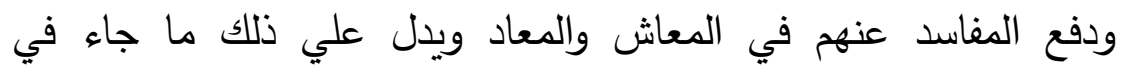

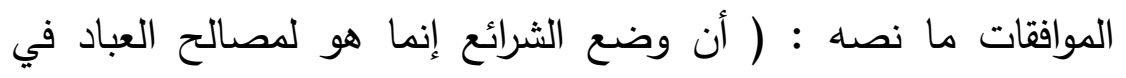

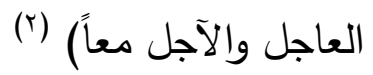
ولعل الغفلة عن هذا باب المقاصد الثرعية أدَت ببعض المشتغلين بظواهر النصوص إلي الاكتفاء بالوقوف علي حرفية النصوص وعدام النام

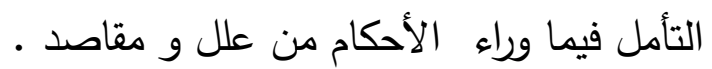
ومن الأمثلة علي ذلك : اصرار بعض الإمن العلماء علي إخراج زكاة

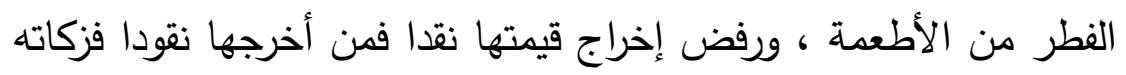

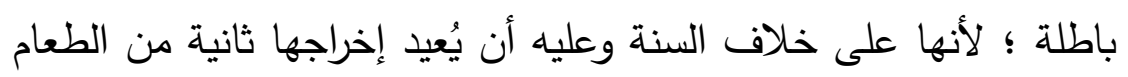

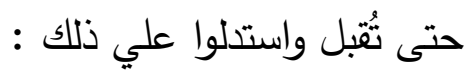

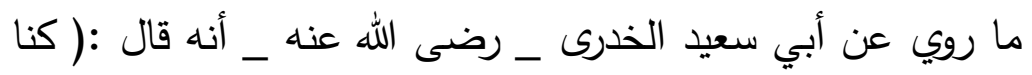

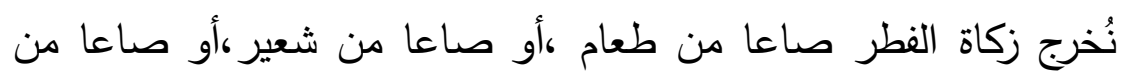

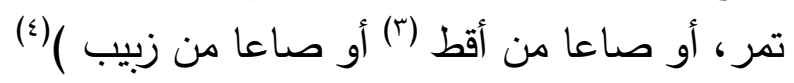

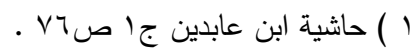

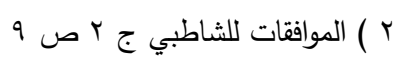

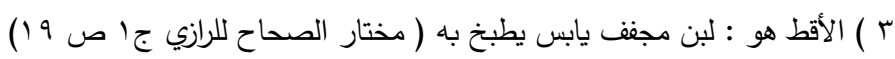

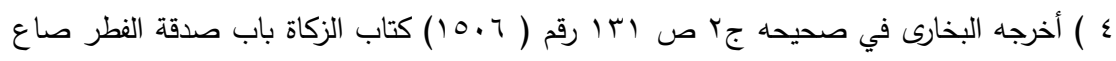

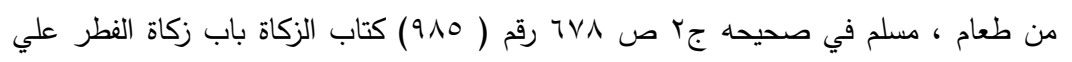
المسلمين من التمر والشعير 
فقد وقف أصحاب القول على ظاهر النص فيما عينه النص من أصناف الطعام دون النظر إلى مقصد الشرع من إغناء الفقراء والمساكين عن السؤال في يوم العيد (') ويـدل علي ذلك :مـا روي عن ابـن عمر _ رضـى الله عنـهـ ـ أنه قال :

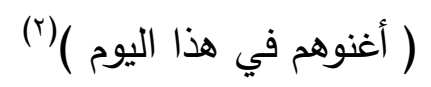

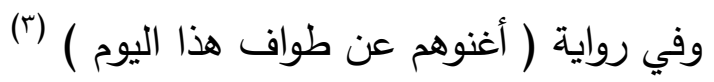
فينبغي النظر إلى العلة والمقصد الشرعي من الحكم والتمييز بين الوسائل والمقاصد ، فزكاة الفطر ليست عبادة مالية محضة وتوقيفية لا مدخل للعقل فيها ، بل هى عبادة مالية معقولة المعني كزكاة الأموال ويجب عند الاشتباه النظر إلي الأنفع للفقير والأيسر علي المكلف فإخراج القيمة نقدا في عصرنا هو الأيسر علي المعطي والأنفع للآخذ .

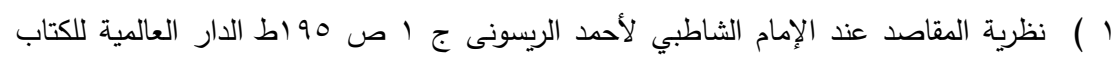

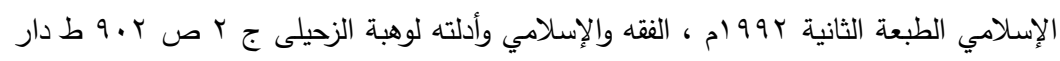

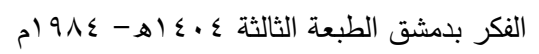

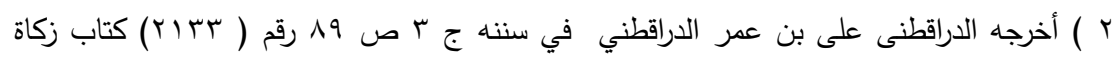

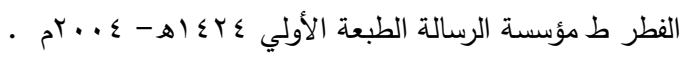

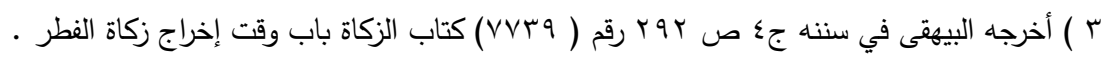




\section{الفصل الثالث}

( أهمية الأمن الفكري ، والجهات المنوطة به ، وأثر الفتاوى الشاذة

عليه ، بعض قرارات مجمع الفقه والمؤتقرات الخاصة بـالإقتاء )

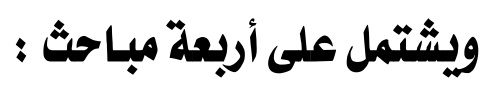

المبحث الأول / أهمية الأمن الفكري واعتبـاره مقصداً من مقاصد الشريعة

الإسلامية. المبحث الثاني / الهيئات المنوطة ببث الأمن الفكري .

المبحث الثالث / أثر الفتاوى الشاذة على الأمن الفكري ـ

المبحث الرابع / بعض قرارات مجمع الفقه والمؤتقرات الخاصة بـالإفتاء 


\section{المبحث الأول ( أهمية الأمن الفكري واعتباره مقصلاً من مقاصد الشريعة )}

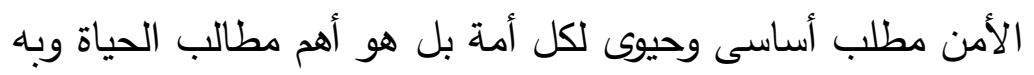

الوصول إلى أعلى درجات الاطمئنان والثعور بالسلام وهو نوعان :

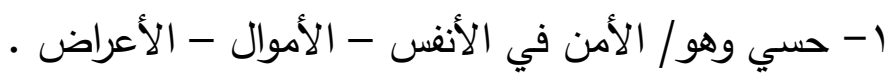

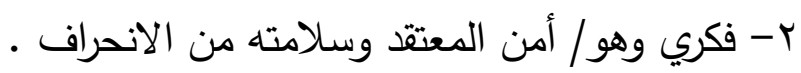
ولعل أكبر دلالة على مفهوم الأمن في الإسلام ما ورد في كتاب الأحراف

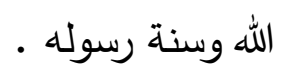

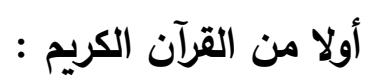

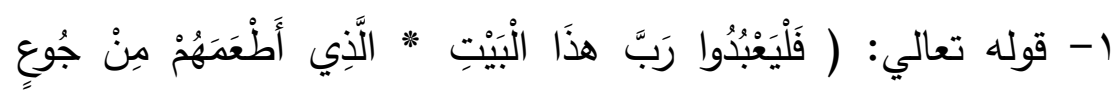

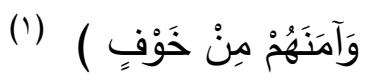

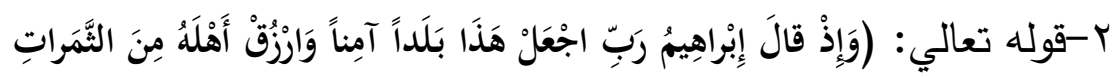

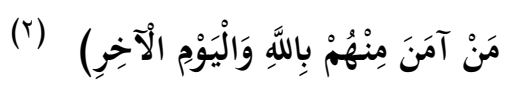

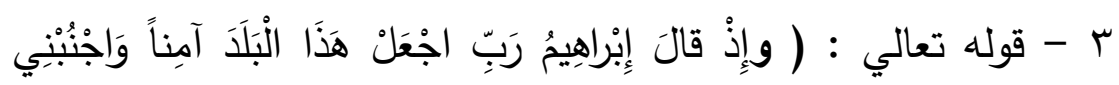

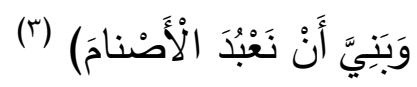

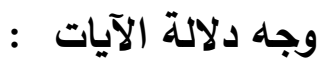

في الآيات دليل علي أن الأمن هو مواجهة الخوف وكل ما يهدد

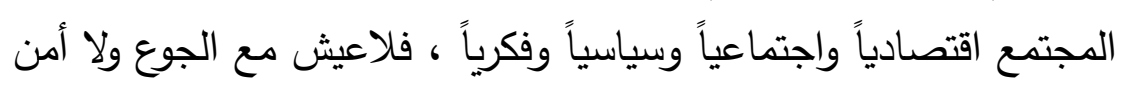

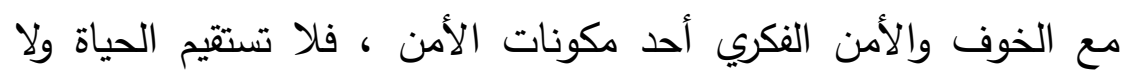

$$
\begin{aligned}
& \text { ( ) سورة قريش آية رقم (r،؛) }
\end{aligned}
$$

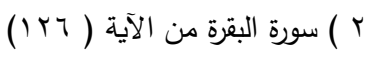

$$
\begin{aligned}
& \text { r ) سورة الأنبياء آية رقم (ro) }
\end{aligned}
$$


تؤمن الفتتة بدون الأمن الفكري ولذلك دعا سيدنا إبراهيم أن يخرجه الله من الخوف إلي الأمن والسلامة من الشرك فكريا وعمليا (1) ثانيا من السنة : روي عن عبدالله بن محصن الأنصاري (؟) قال : قال رسول الله (صلى الله عليه وسلم) : ( من أصبح منكم آمنا في سربها معافى في جسده عنده

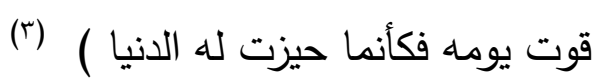
وجه دلالة الحديث :

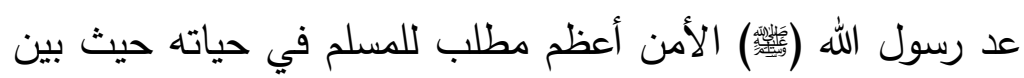
أن من أصبح معافى في جسده عنده قوت يومه فقد جمع الله لله بين

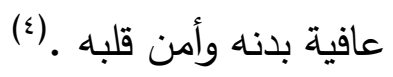

فكل ما ورد من أدلة فيما يحقق الأمن وطمأنينة النفس وزوال

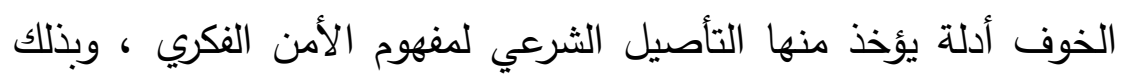
يُعد الأمن الفكري صمام الأمان للمجتمعات وطوق النجاة ، وهو قطب الرحى الذي تدور وترتكز عليه جميع أنواع الأمن وغيابه يؤدي إلى خلل في الأمن في جميع فروعه ولا تؤمن الفتنة ولا الهلاك فالأمم تقاس بعقول

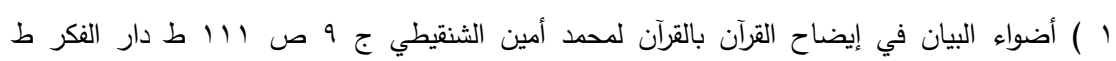

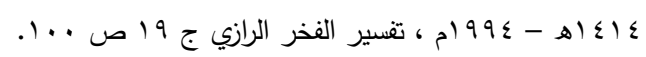

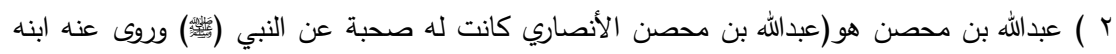

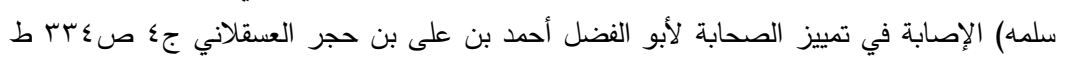

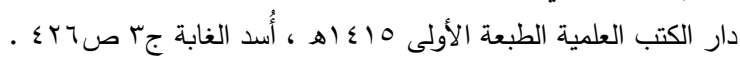

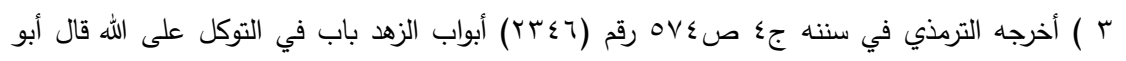

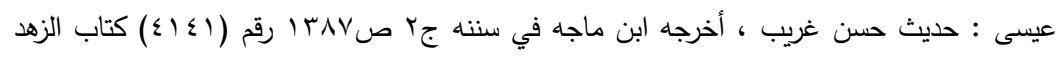
باب القناعة .

؛ ) فيض القدير شرح الجامع الصغير لعبد الرؤف بن تاج المناوي ج V ص VT ط المكتبة التجارية الطبعة

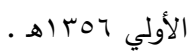


أبنائها ، فإذا إطمان الإنسان إلى ما عنده من أصول وثوابت وقيم ومبادئ

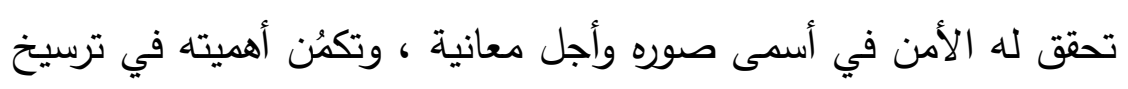

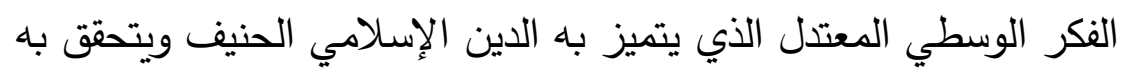

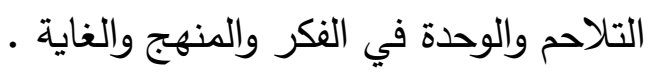

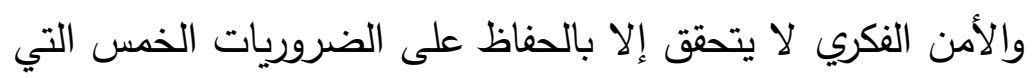

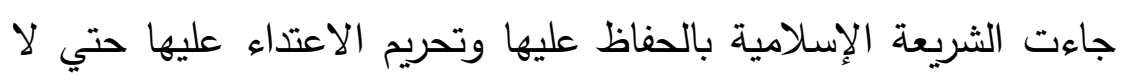

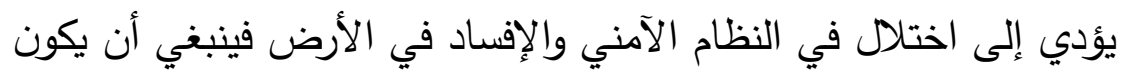

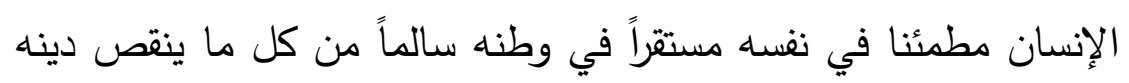

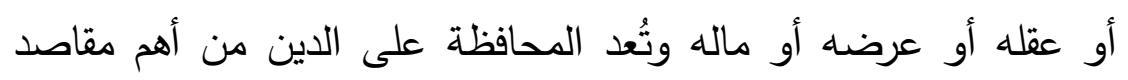

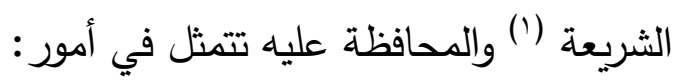

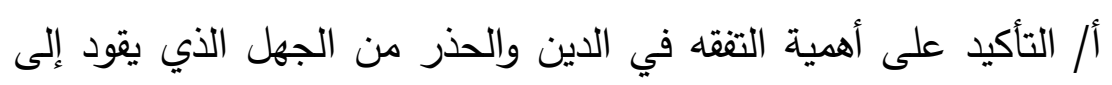
الانحرافات الفكرية . ب/ تحريم الابتداع في الدين فهو من دواعي اضطراب الأمن الفكري وانتشار البدع تحرب البناع

( ) مقاصد الثريعة الإسلايمة تتضمن حفظ الضروريات والحاجات والتحسينات فالضروريات هي / ما تقوم عليه حياة الناس الدينية والدنيوية وإذا فقد اختل نظام الحياة وهي (حفظ الدين -

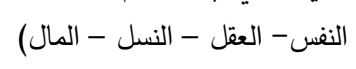

الحاجيات هي / ما يترتب عليع التوسع على الناس ورفع الحرج عنهم مثل مشروعية البيع وسائر المعاملات

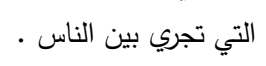

التحسنيات هي / ما تقتضيه مكارم الأخلاق ومحاسن العادات مثل مشروعية الطهارة وستر العورة وآداب

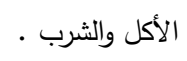

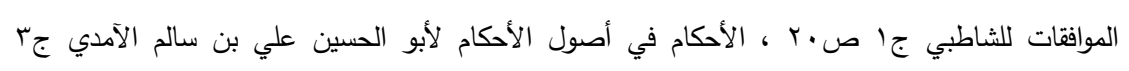

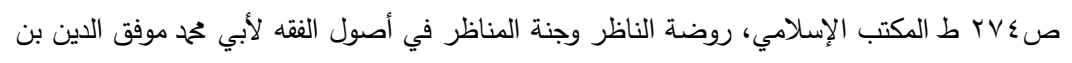

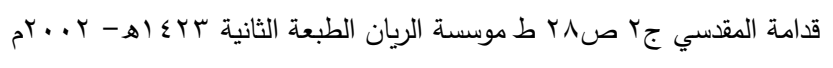


ج/ تحريم الفتوى والقول على الله بغير علم مما يكون سبباً في الوقوع في

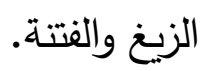

د / تحريم التطرف والغلو في الدين والاعتداء على عقائد الناس والإخلال

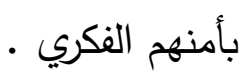
وكذلك يتعلق الأمن الفكري بالعقل الذي هو آلة الفكر والتأمل وقوام كل فعل به مصلحة فاختلاله يؤدي إلى مفسدة عظمى ولذلك كانت المحافظة

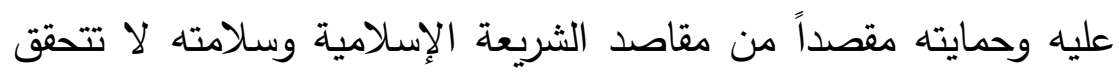
إلا بالمحافظة عليه من المؤثرات الحسية كثرب الخمر والمعنوية كالأفكار

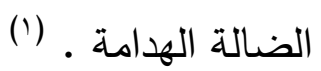

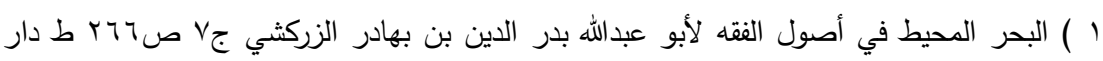

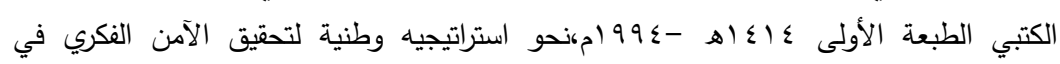

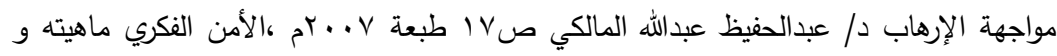

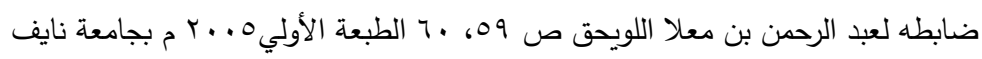




\section{المبحث الثاني / الجهات المنوطة ببث الأمن الفكري}

هناك جهات منوطة ببث الأمن الفكري وتعزيزه في المجتمع وهي(الأسرة

$$
\begin{aligned}
& \text { - المسجد- المؤسسات التعليمية - الإعلام) } \\
& \text { أولاً : الأسرة }
\end{aligned}
$$

تُعد الأسرة المسئول الأول عن الأبناء حقوقاً وواجبات ، واللبنة

الأولى في بناء المجتمع وتعزيز الأمن الفكري مما يتطلب درجة عالية من الانياء

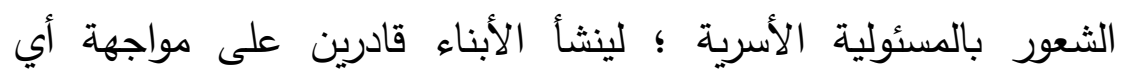

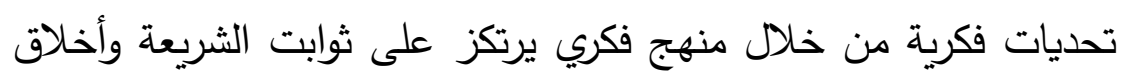

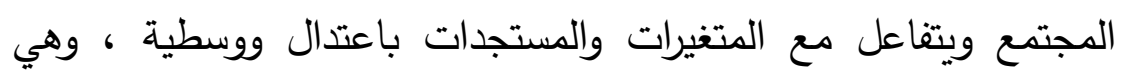

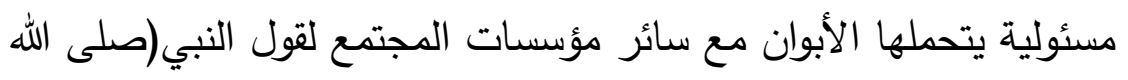

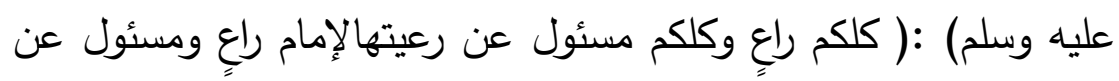

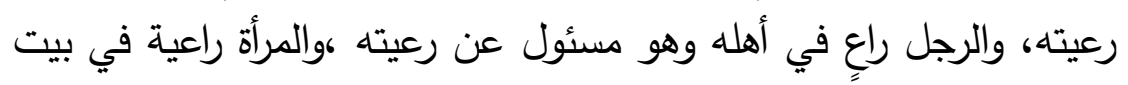

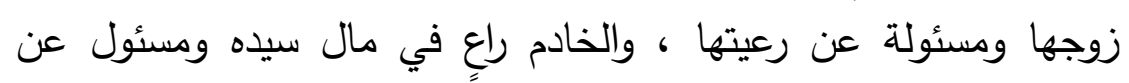
(') (رعيته ) (بوجا

و حيث لا غنى للأبناء عن الرفقة والصُحبة كان على الأبوين

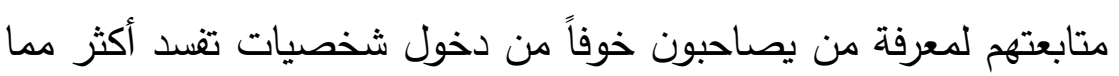

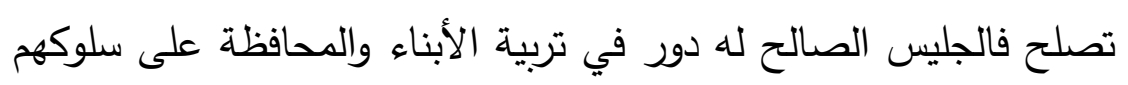

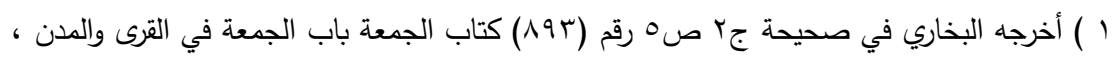

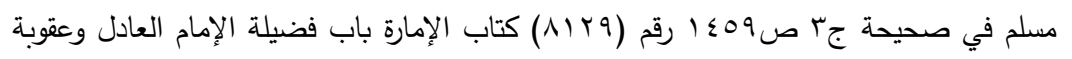

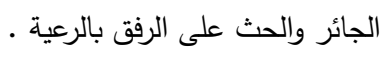




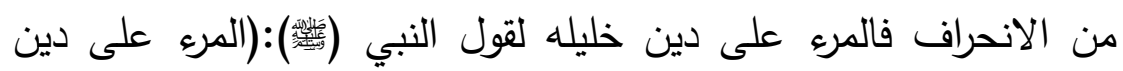

خليله، فلينظر أحدكم من يخالل)(')

ولتحقق ذلك لابد من ممارسة الحوار الجاد الفعال داخل الأسرة لحماية أفراد الأسرة من التطرف والانحراف ، والبعد عن ممارسة العنف والاستبداد والعصبية التي تجافي قيم الثورى في الإسلام ولا تتناسب مع

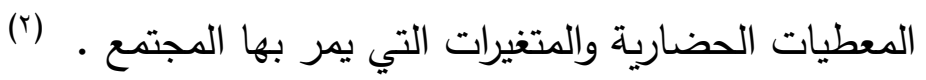
ثانياً : المسجد يُعتبر المسجد من أهم المؤسسات التربوية في المجتمع؛ فهو يغرز القيم في الضمير المجتمعي ويدعو إليها وينمى الإحساس والثعور المتبادل بالجماعة والتآزر والتآخي والتضامن والسعي في خدمة المجتمع ولئي

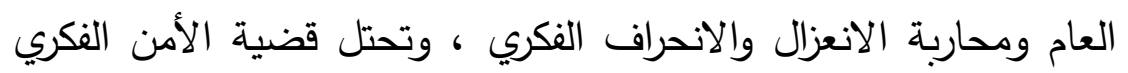

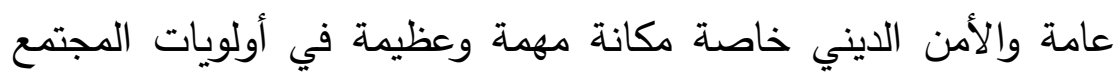
التي تتكاتف وتتأزر جهود أجهزته الحكومية والمجتمعية لتحقيق مفهوم الأمن الفكري؛ تجنباً لتشتت الثعور الوطني أو تغلل التيارات الفكرية المنحرفة ؛وبذلك يؤدي المسجد دوراً وقائياً بنشر الوعي الفكري والثقافي القائم على المرجعية الدينية الوطنية ، ولذلك يجب إحياء رسالة المسجد ولدي

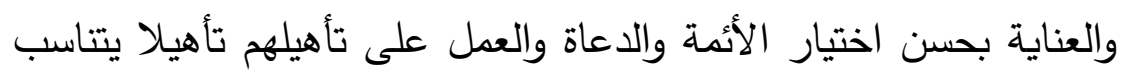

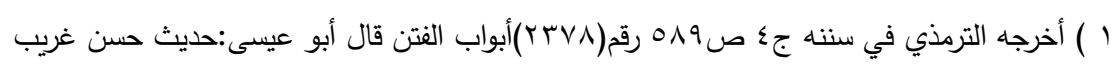

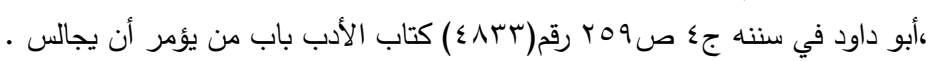

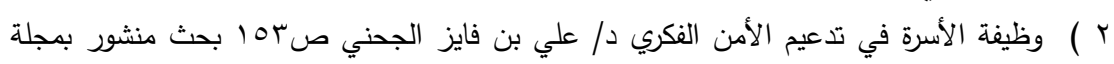

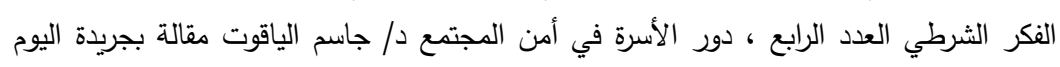


مع طبيعة العصر مع ضرورة المحافظة على الثوابت الإسلامية بغير

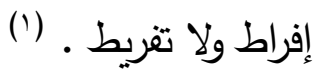
ثالثاً : المؤسسات التعليمية تُعتبر المؤسسات التعليمية الحضن الثاني بعد الأسرة في بناء

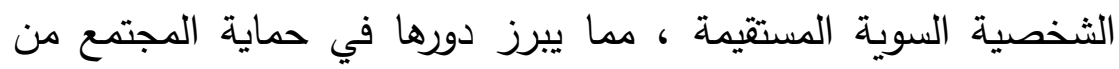
الانحراف الفكري ، ويتحمل المعلم الجزء الأكبر في تعزيز الأمن الفكري

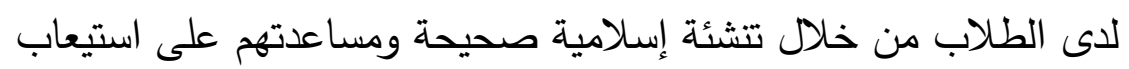
المفاهيم والأفكار الصحيحة، وكذلك ترسيخ مبادئ الحوار الهادف

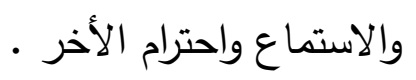

وتُعد مناهج التعليم من أهم وسائل نشر الأمن الأن الفكري لدى الطلاب بغرس العقيدة الصافية والمنهج الوسطى المعتدل واستبعاد النظريات المتطرفة والأفكار المنحرفة ، فعلي المؤسسات التربوية والتعليمية أن تنسق مع مؤسسات المجتمع المدنى لطرح هذه القضايا ووضع الخطط

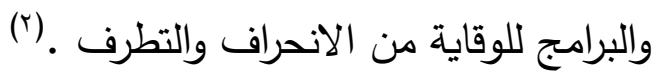
رابعاً : الإعلام

يعتبر الإعلام أهم ما يؤثر في الفكر ويوجهه ويغير ثوابته ، الإعلام

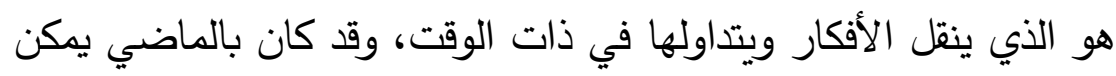
التحكم في كثير من وسائل الإعلام ( الصحف - التلفاز - الجرائد - دئ دان ( ) أثر الانترنت على الأمن الفكري د/عبدالله محمد الثهري ورقة عمل مقدمة للملتقى العلمي نحو

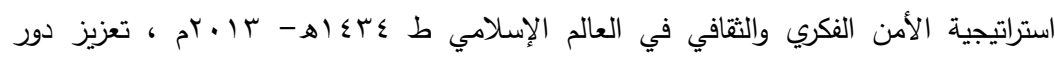

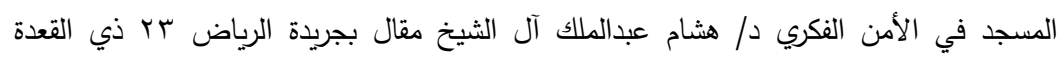

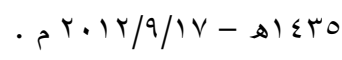
r ) دور المناهج التربوية في تعزيز الأمن الفكري د / الطيب أحمد المصطفي ص ع عه معث منشور

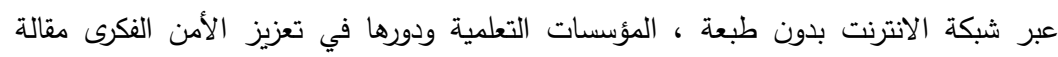

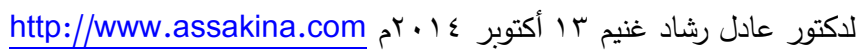




\section{الفتاوى الشاذةوأثرها على الأمن الفكرى}

المجلات) بمراقبتها وتقويم ما ينشر فيها ، أما الآن في ظل ما شهدته الآنه وسائل الإعلام الحديثة ووسائل التواصل الاجتماعي من تطور هائل

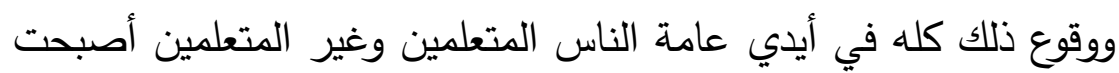

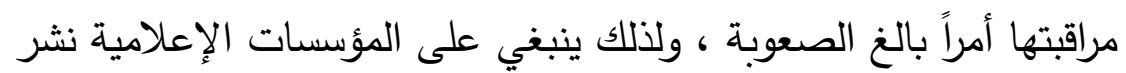

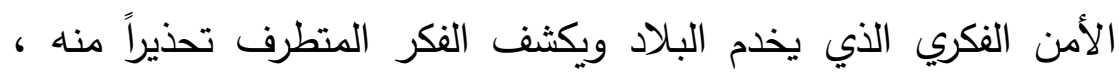

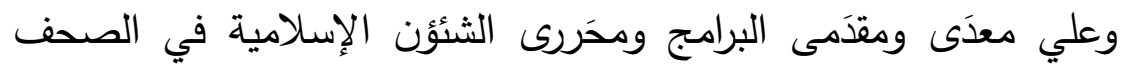

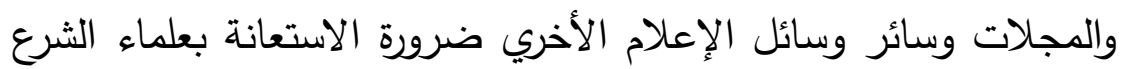

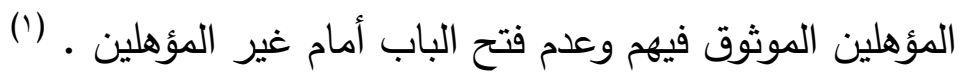

1 ) أثر الانترنت على الأمن النكري د/ عبدالله الثهري ص • (، ظاهرة الفتاوي الثاذة د/ أحمد الهليل

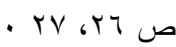




\section{المبحث الثالث / أثر الفتاوى الشاذة على الأمن الفكري}

الثذوذ في الفتوى له مفاسد جسيمة وأخطار عظيمة ومما يزيد في خطورته أنه يمس جميع الأبواب الفقهية فيدلس على المتلقين دينهم ويهدد

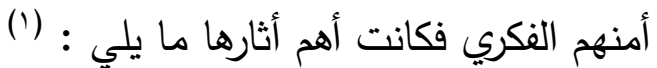
ا - تشويـه صورة الدين الإسلامي وزعزعة الأمن الفكري بترويع الأمنين من خلال الفتاوى الجهادية .

للفتاوى الثاذة أثر في تشويه صورة الدين الإسلامي والتنفير منه عن طريق إلصاق بعض الأعمال الإرهابية به كدعوى بعض الجماعات

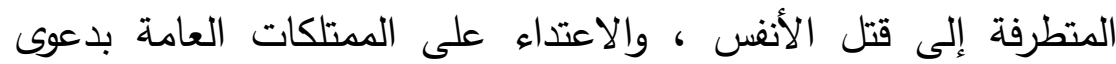
الجهاد، وهي فتوى غير مقبولة عقلاً ولا شرعاً فهناك فرق بين الجهاد (؟)

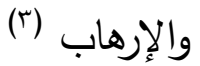

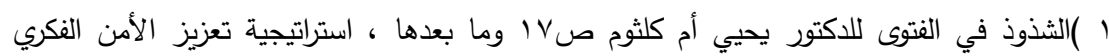

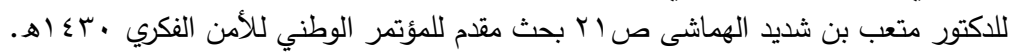

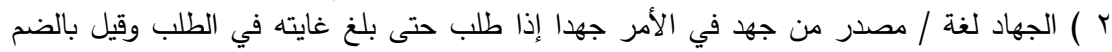

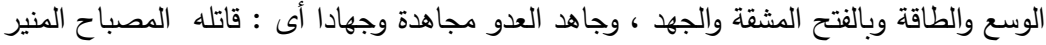

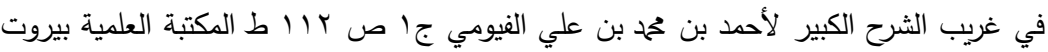

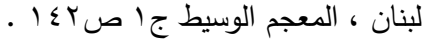

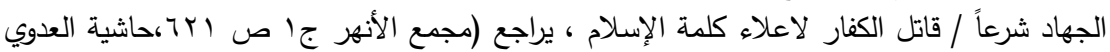

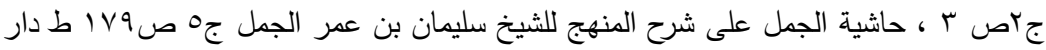

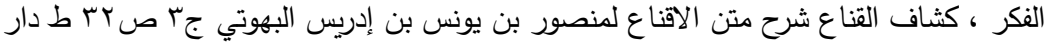

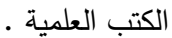
r ) الإرهاب لغة / مصدر رهب ورهبت الثيء أرهبه واسترهبه أي : أخافه ( العين للفراهيدى ج؛ ( صن

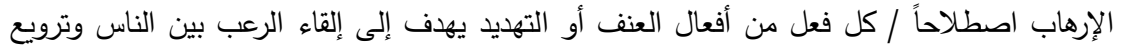

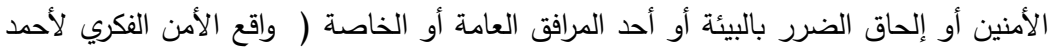


فالأصل في العلاقة بين المسلمين وغيرهم علاقة تعايش وسلام ، لا علاقة عداء وحرب ، ما داموا مسالمين فالاصل في العقيدة هو الحرية وإنه لا إكراه في الدين، فأكثر من يتبنون الفكر الجهادى يجهلون لماذا شرع الجهاد ؟ ومتى شرع ؟ فالجهاد شُرع من أجل إعلاء كلمة الدين

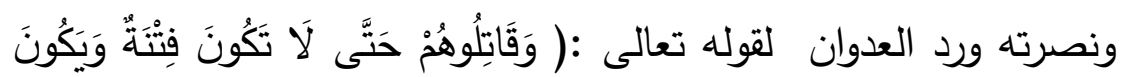

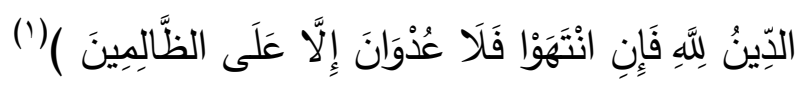
ففي الآية دليل علي أنه ليس المقصود من الجهاد قتل غيل غير الهير المسلمين ولكن المقصود أن يكون الدين الله تعالي وأن يظهر دينه علي سائر الأديان ويدفع كل ما يعارضه من الشرك وهو المراد من الفتنة، فإذا

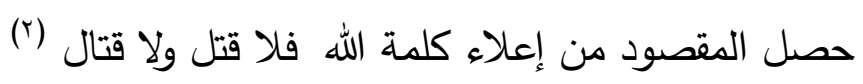

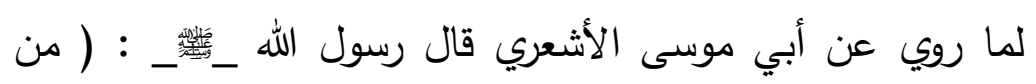

قاتل لتكون كلمة الله هي العليا، فهو في سبيل الله ) (r) والجهاد الشرعي إلا يكون إلا بشروط عدة ذكرها الفقهاء منها : وجوب الاستعداد للقتال، وتجنب قتال الأبرياء دن النساء والشيوخ والأطفال وأماكن العبادة وأهل الذمة والعهد، وإذن الإمام ولو جار أو فسق ونق

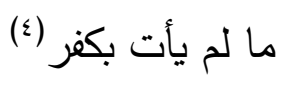

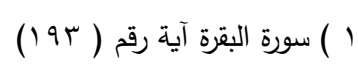

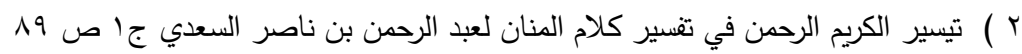

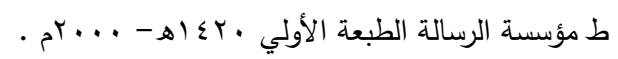

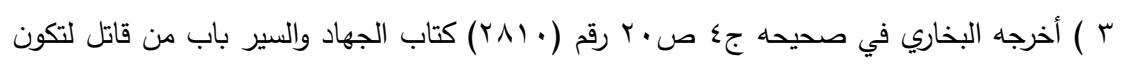
كلمة الله هي العليا.

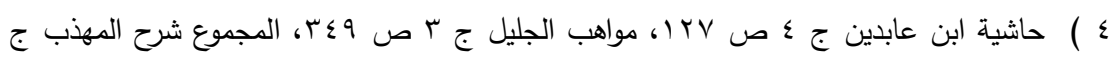

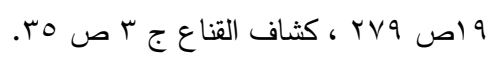


أما ما يجرى في العالم من قتل الأبرياء، وترويع الآمنين، وتخريب

الممتلكات ليس جهاداً أنما هو إرهاب وعنف وتتطرف وانحراف فكري، وقد أطلقت الشريعة الإسلامية علي من يشهر السلاح لإخافة الآمنين محارباً ومفسداً في الأرض ويدل علي ذلك أ- قوله تعالي : ( إنَّما جَزاءُ

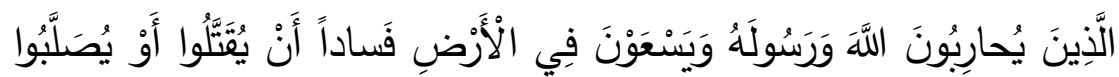

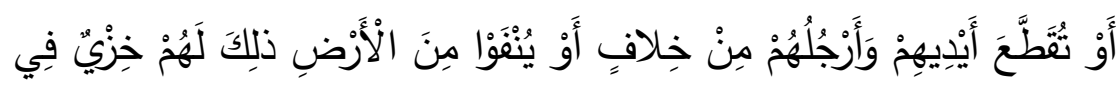

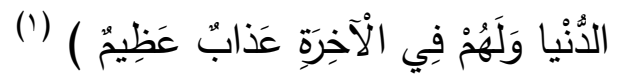
ب- ما روى عن أبي هريرة ـ رضى الله عنه _أن النبي _ ــلي الله عليه وسلم _ قال: سمعت رسول الله يقول:(من أشار إلى أخيه

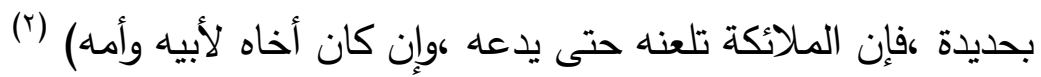
فبذلك يتبين أن الفتاوى الشاذة والغلو والتطرف فيها يؤدى إلى لى لئه زعزعة الأمن الفكري لدى المجتمع عامة والثباب خاصة بأفكار ضالة وتوجهات مشبوهة ، فما يشهده العالم من إرهاب وتدمير وإخلال بالأمن الوطني إنما هو نتيجة لفقدان الأمن الفكري أو اختلاله .

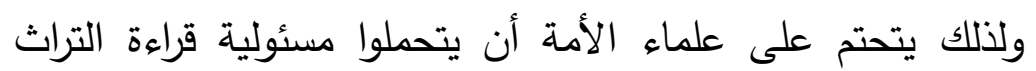
الإسلامي ومراجعة لتصحيح المفاهيم والكثف عن الفهم الصحيح للنصوص لنحمي شبابنا من دعاة العنف ومروجى التكفير ليتحقق الاستقرار والرخاء والأمن الفكري .

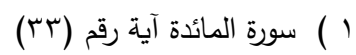

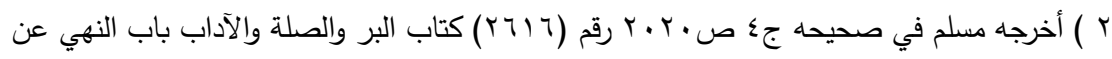
الإشارة بالسلاح إلى مسلم . 


\section{r) تعليم الناس الحيل غير الثرعية (1)}

الحيل غير الشرعية هي مخارج غير شرعية لم يقرها الشرع ولم يأذن بالعمل بها ؛ منعاً لأصحاب الأغراض الفاسدة والنوايا السيئة من التحايل

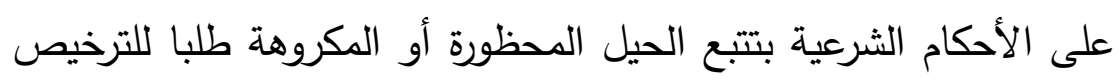

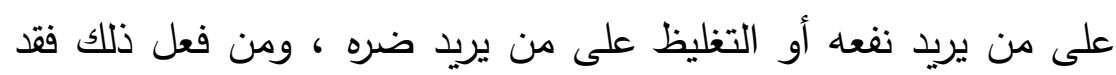

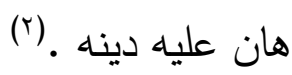

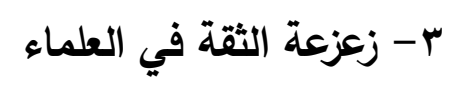

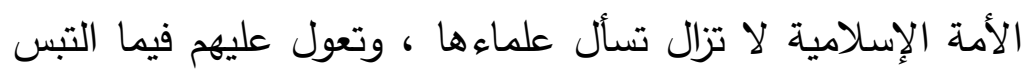

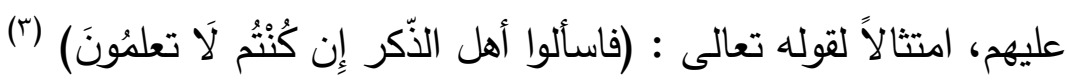
فإذا جاءت الفتوى صحيحة فبها ونعدت ، وإن جاءت شاذه غرببة

أضعفت مكانة العلماء لدى العامة ، وأدت إلى فقدان الثقة فيهم .

ع - معوبة تداركها بعد انتشارها

يصعب تدارك الفتوي بعد انتشارها وبخاصة في القنوات الفضائية

والبرامج الإفتائية المباشرة فيجب على المفتي التثبت والتحري قبل إصدار الفتوى لصعوبة تدارك زلة العلماء؛ حيث تنتشر انتشار النار في الهشيم ولن ينفع أنذالك ردَّ العلماء عليها ولا رجوع العالم عنها ، ويدل علي ذلك رلك الك

( ) الحيل / ما يتخلص به من الحرام أو يتوصل به إلي الحلال فهو حسن ، وإنما يكره أن يحتال في

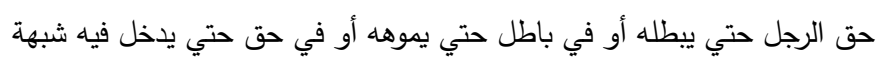

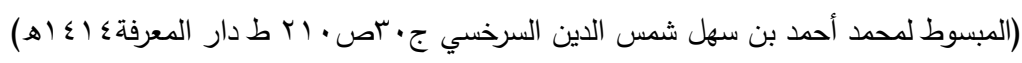

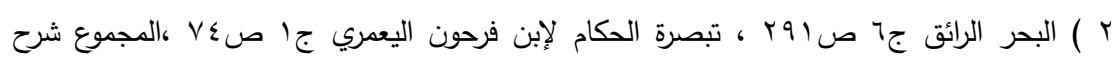

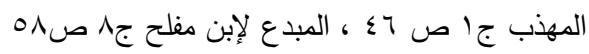

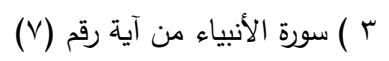


قول عمر بن الخطاب رضى الله عنهـ_ : ( يهدم الإسلام ثلاثة : زلة

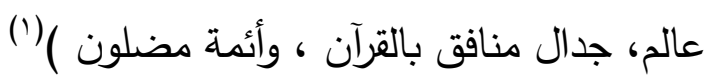
ه- تضليل العامة وصرفهم عن القضايا الهامة وتوسيع دائرة الجدل . خلقت الفتاوى الثاذة جواً مشحوناً بالمهاترات بين العلماء ، مما

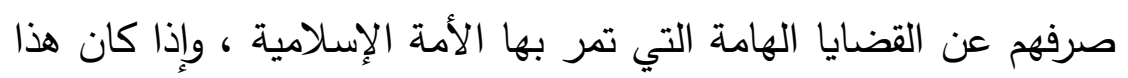
هو حال العلماء فلا يلم أحد عامة الناس حين يعظمون سفاسف الأمور ويتجاهلون عظائمها منشغلين بالسعي وراء غذاء الجسد دون غذاء الروح. צ- ضرب اقتصاد الدول الإسلامية تُعد الفتاوى الثاذة التي لا تمتُّ للدين بصلة سُماً قاتلاً ينتشر في الإسئ جسد الدول الإسلامية يشلها تمهيداً للقضاء عليها ، سياسياً ، واجتماعياً ، وفكرياً من خلال العبث بمقدراتها واستغلال مواردها وذلك باستنزاف ثرواتها في إعادة بناء ما خربه التدمير بدلاً من إنفاقه في مجالات التقدم • والتطوير

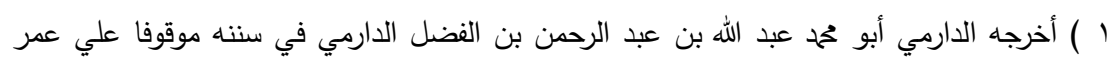

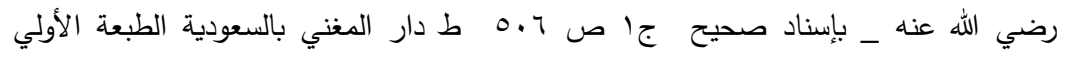

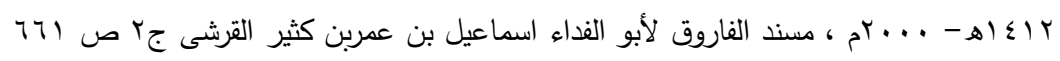

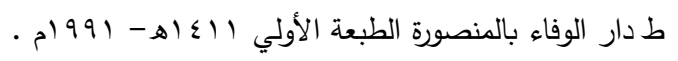




\section{المبحث الرابع ( بعض قرارات مجمع الفقه والمؤتقرات الخاصة بـالإفتاء )}

توصيات مؤتمر الفتوي وضوابطها في دورة السابعة عشر لمجمع الفقه

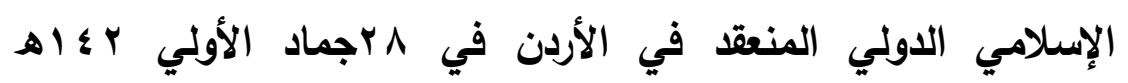

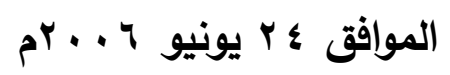

( ) يوصي المجمع بدوام التواصل والتنسيق بين هيئات الفتوى في العالم الإسلامي للاطلاع على مستجدات المسائل، وحادثات النوازل. أن يكون الإفتاء علماً قائهاً بنفسه، يُدرس في الكليات والمعاهد الثرعية، ومعاهد إعداد القضاة والأئعة والخطباء.

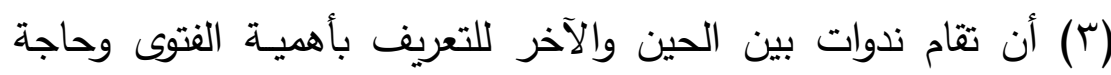
الناس إليها، لمعالجة مستجداتها.

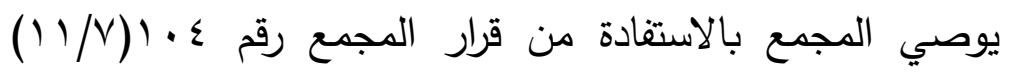
الخاص بسُبل الاستفادة من الفتاوى، وبخاصة ما اشتمل عليه من لن لان

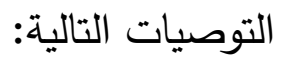

( أ ) الحذر من الفتاوى التي لا تستند إلى أصل شرعي ولا تعتمد على أدلة معتبرة شرعا، وإنما تستتد إلى مصلحة موهومة ملغاة شرعا نابعة من الأهواء والتأثر بالظروف والأحوال والأعراف المخالفة لمبادئ وأحكام الشربعة ومقاصدها.

( ب ) دعوة القائمين بالإفتاء من علماء وهيئات ولجان إلى أخذ قرارات وتوصيات المجامع الفقهية بعين الاعتبار، سعيا إلى ضبط الفتاوى

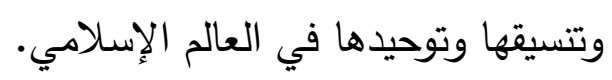


قرارات مؤتمر الفتوي وضوابطها الذي عقده المجمع الفقهى برابطة العالم

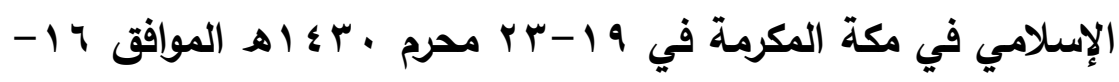

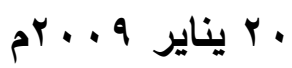

أولاً/ اصدار ميثاق للفتوى يتواصى المؤتمرون علي التقيد به ويدعون ولاة

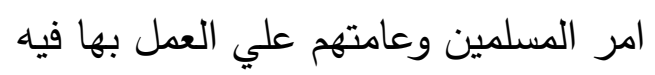
ثانياً/ توصيات عامة تتعلق بأمور الفتوى ودعم مؤستها كان من أهم فئه أهم

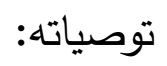

إنشاء معاهد عليا للإفتاء، يدرس فيها المتفوقون من خريجي كليات

$$
\text { الشريعة ليتأهلوا لهذا الثأن. }
$$

وقد استجابت دار الإفتاء المصرية لهذه المطالب وتلك الدعوات،

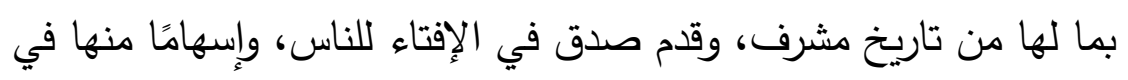

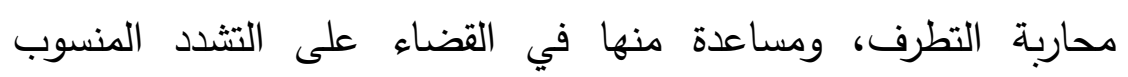

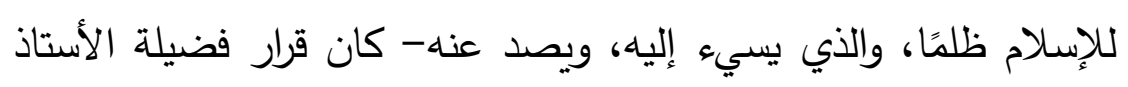

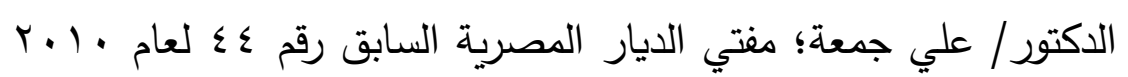

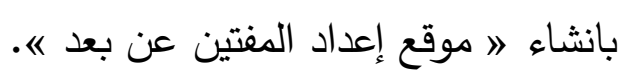

قرارات مؤتمر دور الفتوي فى استقرار المجتمعات الذي نظمته الأمانة

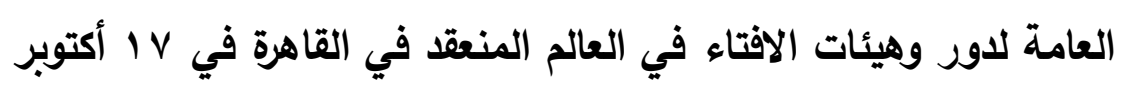
Fr. IV

وقْذ خرجَ المؤتَمرُ في ختامِه بمجموعةٍ مِنَ التوصياتِ والقراراتِ

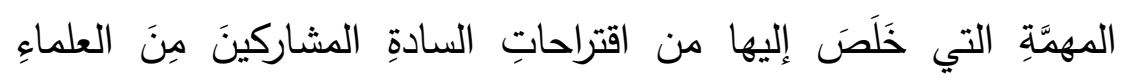

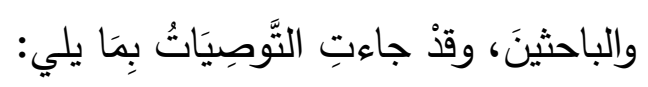

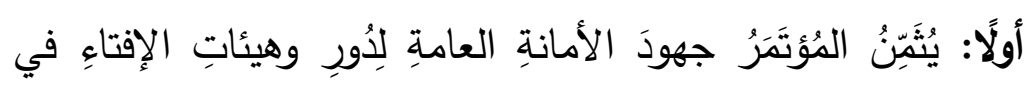

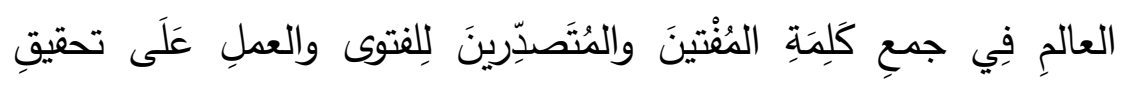




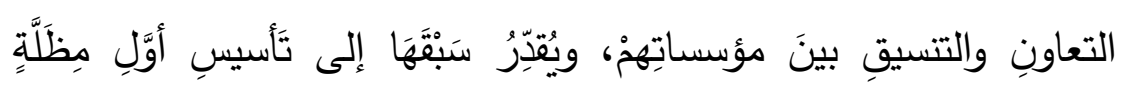

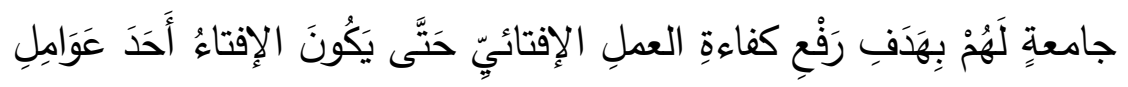
الاستقرارِ والتتميةِ والتحضُّرِ للإنسانيةِ كافَّةً.

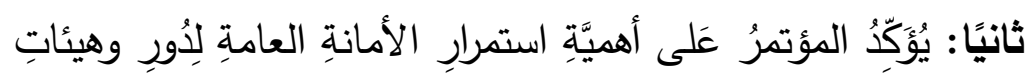

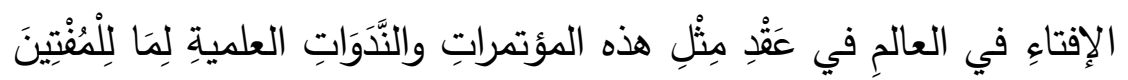

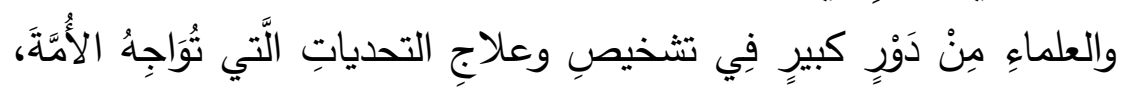

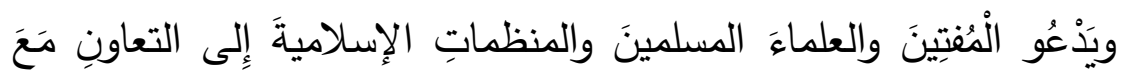

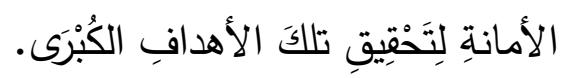

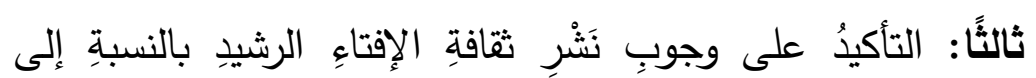

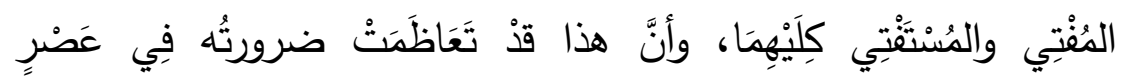

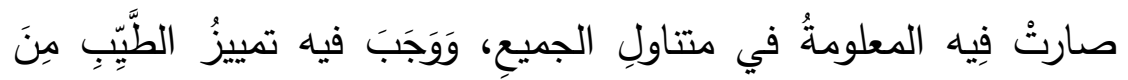
الخبيثِ والْغَنِّ مِنَ السَّمِينِ.

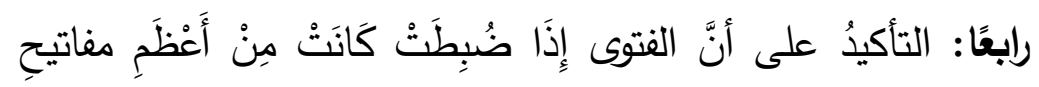

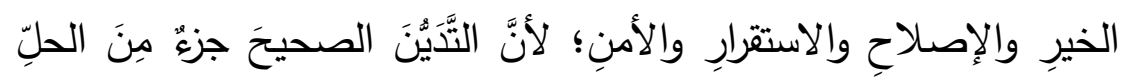

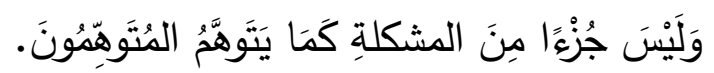

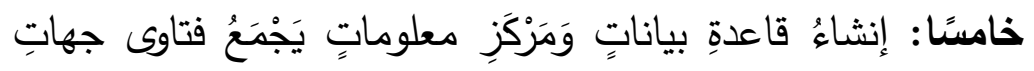

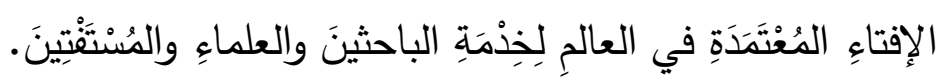

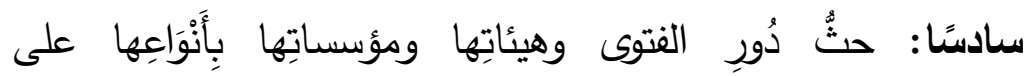

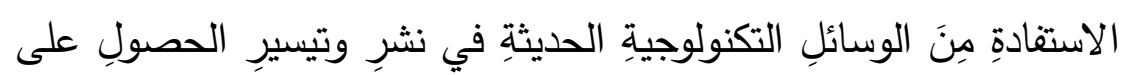

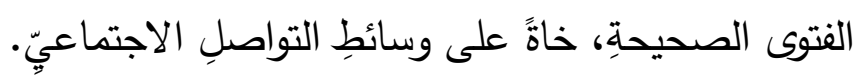

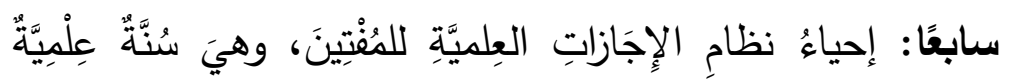

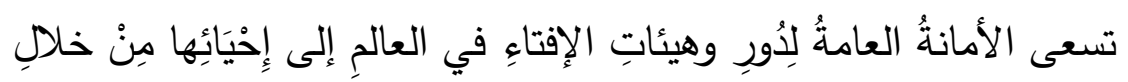

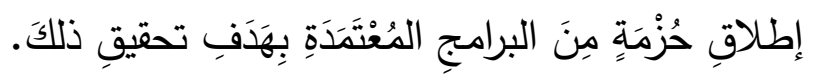


ثامنًا: التأكيدُ على ضرورِ التجديدٍ في قضايا الإفتاءٍ شكلًا

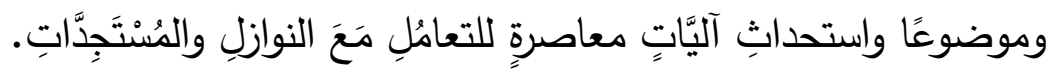

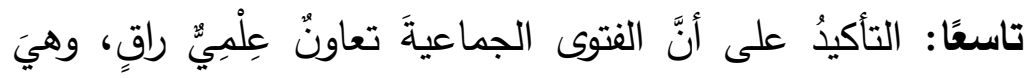

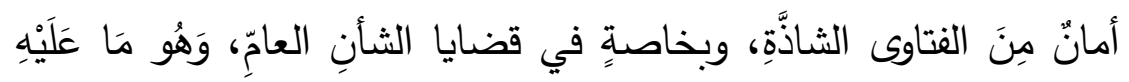

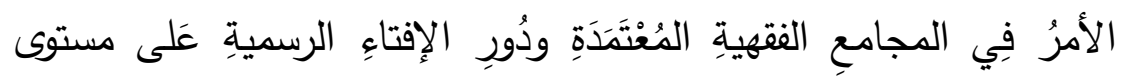
العالمِ الإسلاميّي.

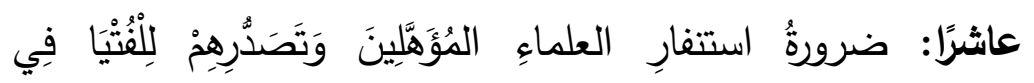

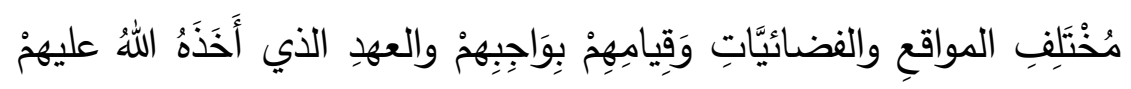

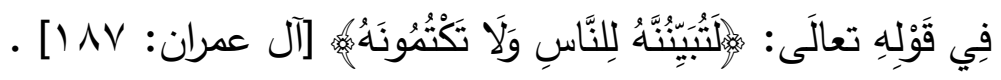

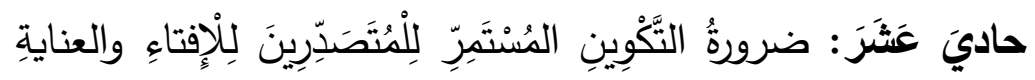

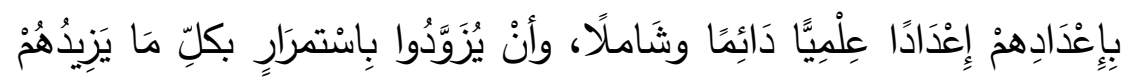

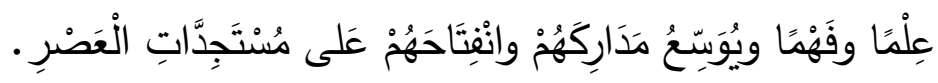

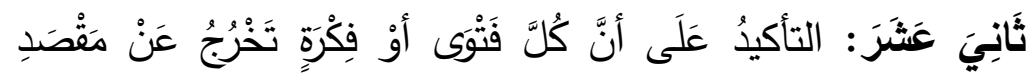

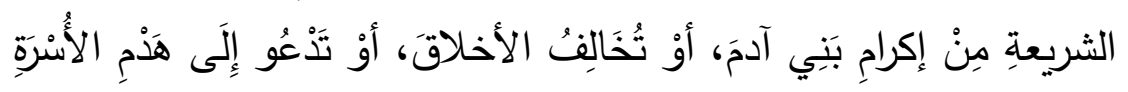

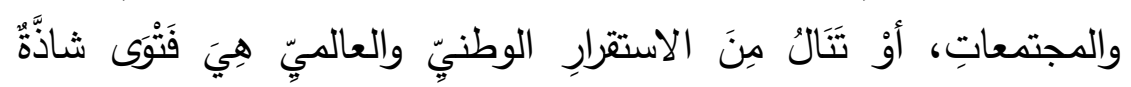

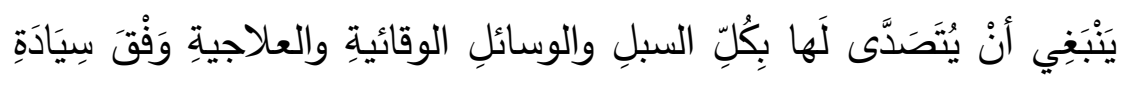
القانونِ.

ثَالََْ عَشَرَ: التأكيدُ على وُجُوبِ التواصُلِِ العِلميّ بينَ دوائرِ العلومِ

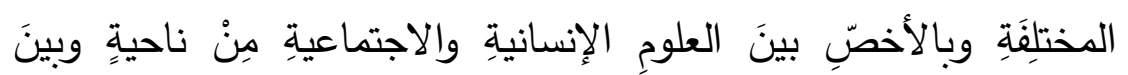

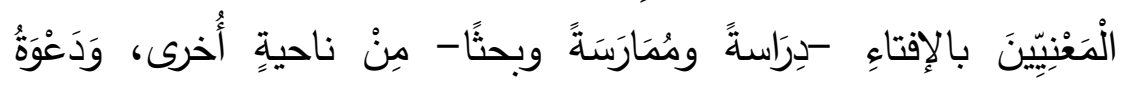

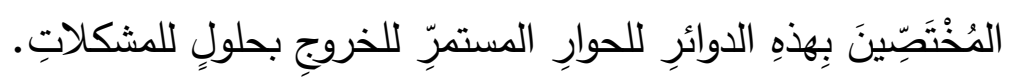




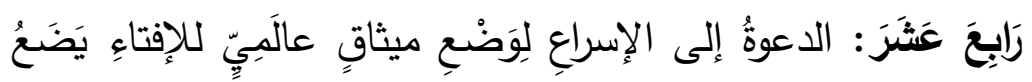

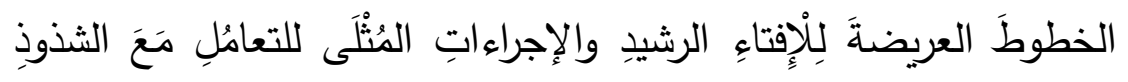

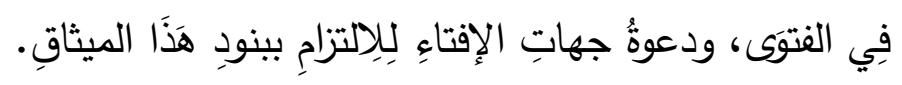

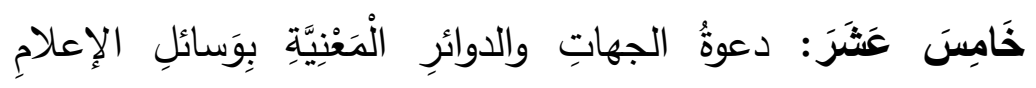

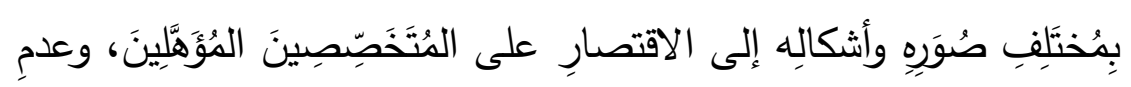

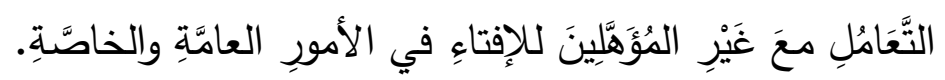

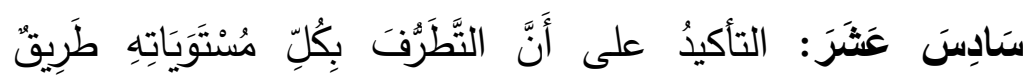

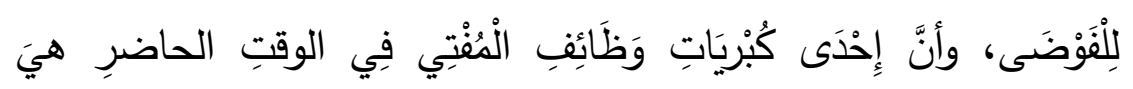

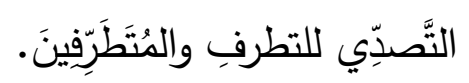

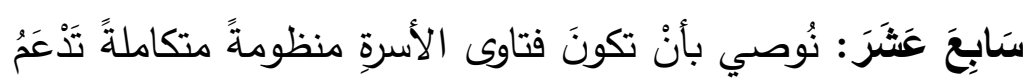

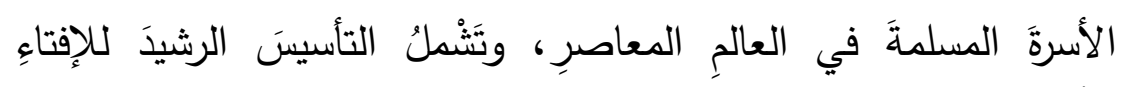

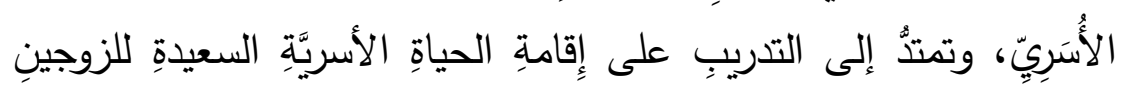

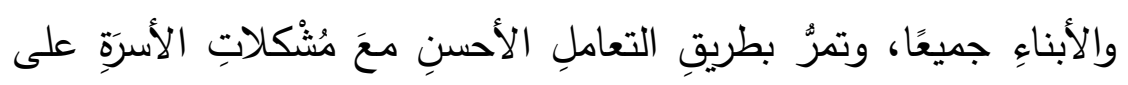
اختلافِهِا ومِنْ كافَّة جوانِنِها.

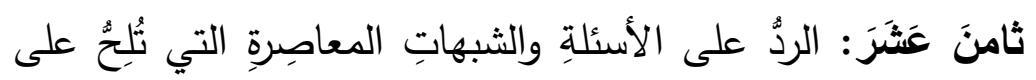

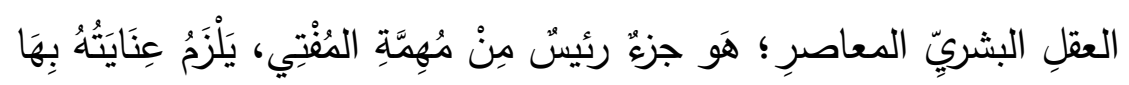
والتنَّرُبُبُ للردِّ عَلَيْهَا.

تاسِعَ عَشَرَ: يُوصي المؤتمرُ بإدراجِ مادَّة أُصولِ الإفتاعِ باعتبارِها

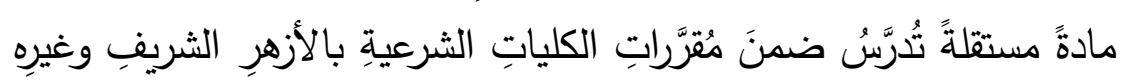

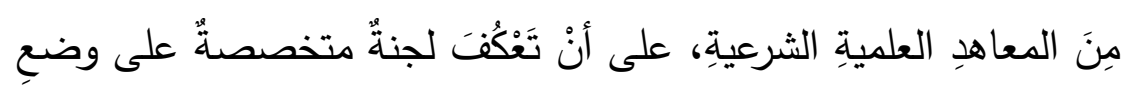

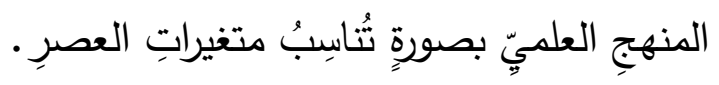




\section{الخاتقة}

أحمد الله _سبحانه وتعالىـ_الذي وفقني وأعانني على كتابة هذا

البحث المتواضع وقد توصلت من خلاله إلى أهم النتائج التالية : 1- الفتوى الثرعية : إخبار عن الله_عز وجل_ وتبيين الحكم الثرعي

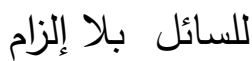

r- الفتوى الثاذة : هي الفتوى المخالفة للدليل الشرعي المضيعة لمصالح

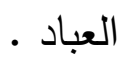

r- الأمن الفكري : سلامة فكر الإنسان وعقله وفهمه من الانحراف

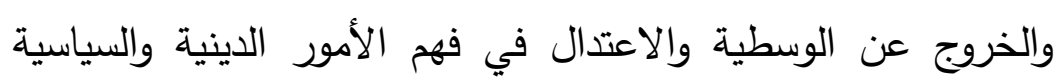
بعيداً عن الغلو والتتطع والالحاد

ع - وضع الفقهاء شروط عدة للفتوي :

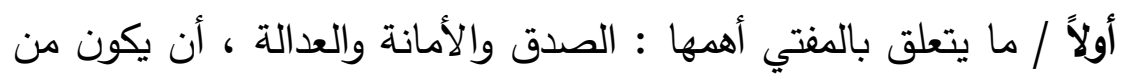

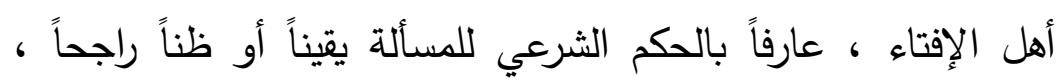

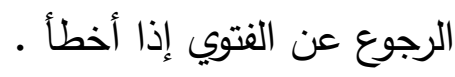

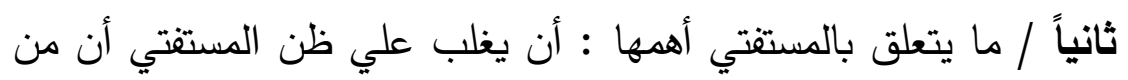

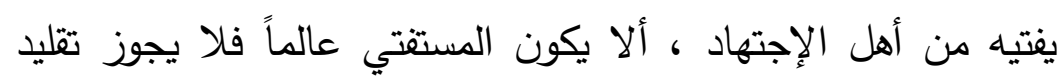

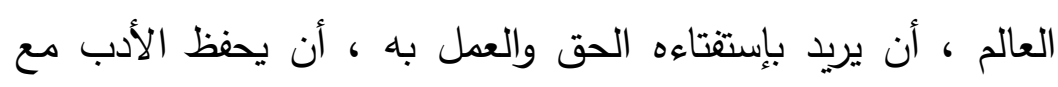

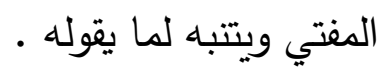
ثالثاً / ما يتعلق بزمن ومكان الفتوي : يجب علي المفتي أن يكون علي

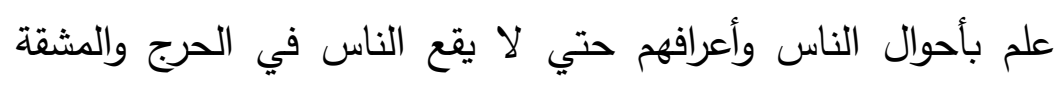

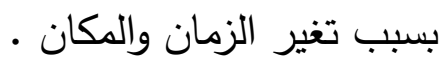


0- للفتاوى الشاذه أسباب كثيرة أهمها : صدورها من غير المختصين ، الفهم الخاطئ للنصوص ، عدم معرفة المفتي في بعض الأحيان بألفاظ المستفتي، التساهل في الفتوى وتبني الآراء الثاذة، حب الثهرة وعدم الوقوف على واقع الناس وأحوالهم والجهل بمقصود الشارع وتتبع الحيل والأهواء ، والتسرع وعدم التأني في إصدار الفتاوى، انفتاح بعض الدعاة والخطباء علي حضارة الغرب، وسائل الإعلام بشتى أنواعها.

ج- وضع العلماء معايير لوصف الفتوى بالثذوذ وهي : أن تعارض نصاً صريحاً ، أن تصدر من غير أهلها، أن لا تراعي الفتوى تغيير الزمان والمكان وأحوال الناس ، أن يكون مستتد الفتوى أمراً متوهماً أو لا لا لأل يصلح أن يكون دليلاً ، ألا يكون مستند الفتوي رأياً غرياً أو ضعيفاً

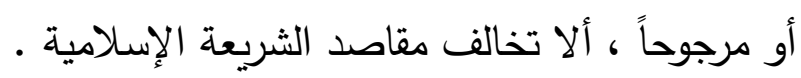
V- الأمن الفكري مقصد من مقاصد الشريعة الإسلامية ، فإذا اطمأن الإنسان إلي ما عنده من أصول وثوابت تحقق له الأمن في أسمي

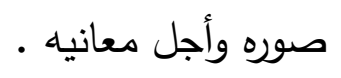
1-أهم الجهات المنوطة ببث الأمن الفكري ( الأسرة- المسجد- معاته

$$
\text { المؤسسات التعليمة - الإعلام) }
$$

9- أهم الآثار المترتبة علي الفتاوي الثاذة تشويه صورة الإسلام وزعزعة الأمن

الفكري ، تعليم الناس الحيل غير الثرعية زعزعه الثقة في العلماء، تضليل العامة وصرفهم عن القضايا الهامة وتوسيع دائرة الجدل ، ضرب اقتصاد الدولة الإسلامية . 
1 - الاعتصام بالكتاب والسنة والتحاكم إلي النصوص الثرعية ، والتزود

بالعلم الشرعي النافع من مصادره الموثوقة .

r- وجود مرجعية جماعية للفتاوى الثرعية من خلال المجامع الفقهية ودور الإفتاء والعلماء المختصين.

ب- يتحتم على علماء الأمة أن يتحملوا مسئولية قراءة التراث الإسلامي ودئ ولاء ومراجعته لتصحيح المفاهيم والكثف عن الفهم الصحيح للنصوص النه لنحمي شبابنا من دعاة العنف ومروجى التكفير ليتحقق الاستقرار

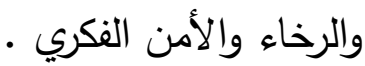

ع- وضع ميثاق لوسائل الإعلام الإسلامية ينتطم ما يعرض وما ينشر فيها فيما يخص الإفتاء مياء 
فهرس المراجع

أولاً : القرآن الكريم

ثانياً : التفسير وعلوم القرآن

1- أحكام القرآن لمحمد بن عبد الله أبو بكر العربي المالكي ط دار الكتب

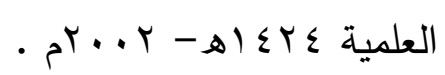

r- أضواء البيان في إيضاح القرآن بالقرآن لمحمد أمين الثنقيطي ط دار

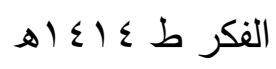

ب- تفسير القرآن العظيم لأبو الفداء إسماعيل بن عمر بن كثير طد دار طيبة

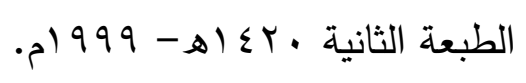

ع- تفسير المراغي لأحمد مصطفى المراغى ط مصطفى الهی البابي الحلبي

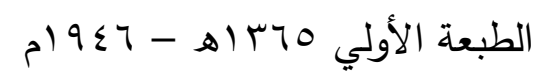

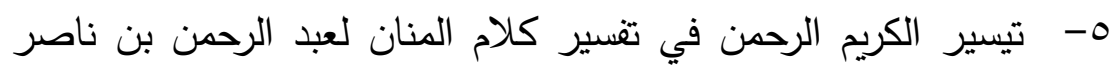

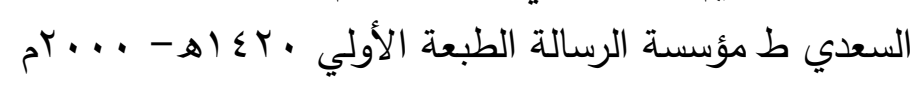

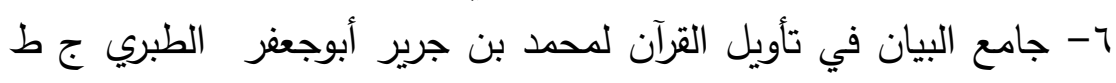

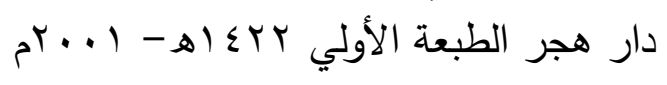

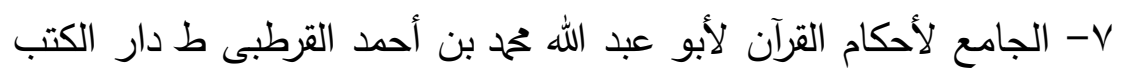

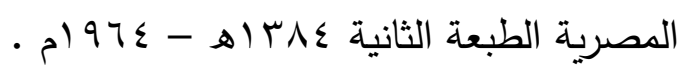

1- مفاتيح الغيب والتفسير الكبير لفخر الدين الرازي طـ دار إحياء التراث العربي الطبعة الثالثة

ثالثاً : الحديث وعلومه الخه

1 - الآثار لأبويوسف يعقوب بن إبراهيم بن حبيب الأنصاري ط دار الكتب

$$
\text { العلمية. }
$$

r- سبل السلام لمحمد بن إسماعيل الصنعاني ط دار الحديث .

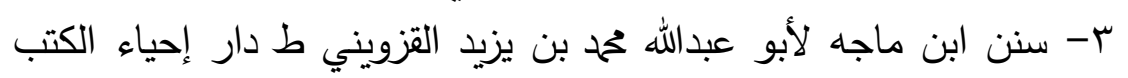

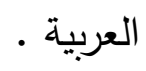

ع - سنن أبى داود لسليمان بن الأشعث السجستاني ط المكتبة العصرية . 
0- سنن الترمذي لمحمد بن عيسى بن سورة ط مصطفي البابي الحلبي

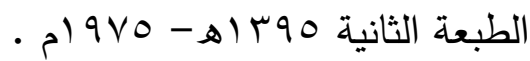

צ- سنن الدارمي لأبو حمح عبدالله بن عبدالرحمن الدارمي ط دار الرار المغني

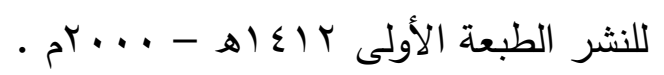

V- سنن الدراقطنى على بن عمر الدراقطني ط مؤسسة الرسالة الطبعة

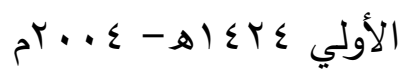

^- السنن الكبرى أحمد بن الحسين البيهقي ط دار الكتب الهب العلمية الطبعة

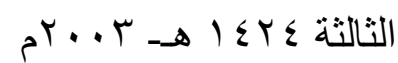

9- شرح السنة لأبو محمد الحسين بن مسعود البغوي طـ المكتب الإسلامي

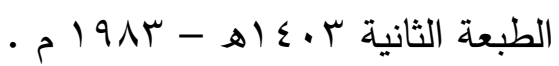

• - - صحيح البخارى لمحمد بن اسماعيل بن إبراهيم البخاري ط دار طوق اهن

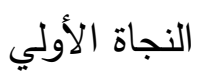

11- صحيح مسلم لمسلم بن حجاج أبو الحسين النيسابوري ط دار إحياء

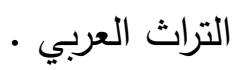

rا - فتح الباري شرح صحيح البخاري لابن حجر العسقلاني ط دار المعرفة . ه IT

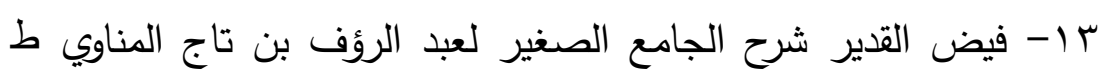

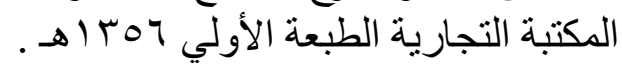
ع ا- المدخل إلي السنن الكبري لأحمد بن الحسين البيهقي ط دارالخلفاء

$$
\text { للكتاب الاسلامي }
$$

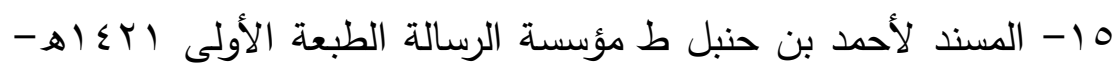

$$
\text { - }+1
$$

7 ا - مسند الفاروق لأبو الفداء اسماعيل بن عمربن كثير القرشى ط دار

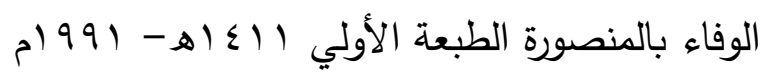

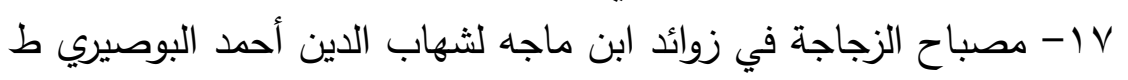

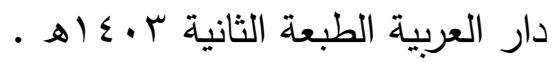


11- مرقاة الدفاتيح شرح مشكاة المصابيح لأبو الحسن نور الدين الملا

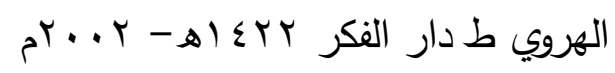

9 1- منار القاري شرح مختصر صحيح البخاري لحمزة لحمد قاسم ط دار دار

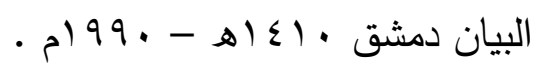

• ץ- الموطأ للإمام مالك بن أهن الهأ الأصبحي ط الدكتبة التوفيقية .

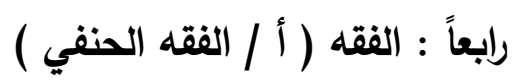

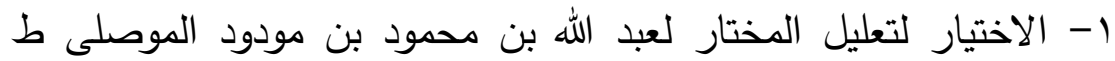

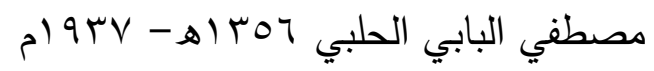

r- البحر الرائق شرح كنز الدقائق لزين الدين إبراهيم بن محمد المعروف بابن الدابن

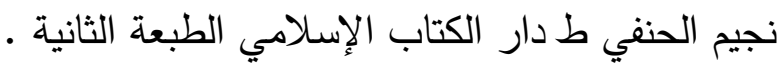

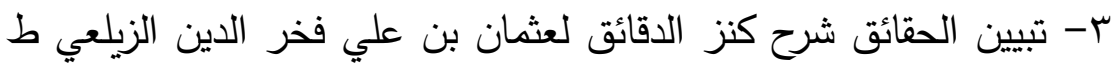

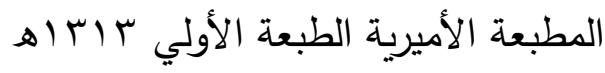

ع- رد المختار على الدر المختار لـحمد أمين بن عمر بن عبدالعزيز

$$
\text { الشهير بابن عابدين }
$$

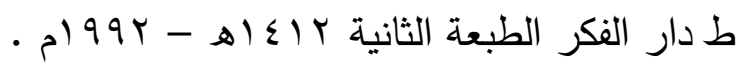

0- المبسوط لمحمد أحمد بن أبي سهل شمس الدائ الدين السرخسي ط دار

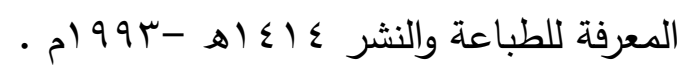

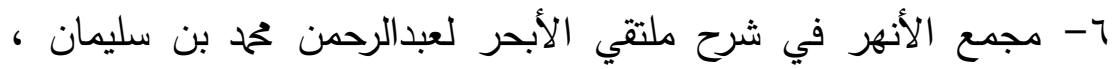

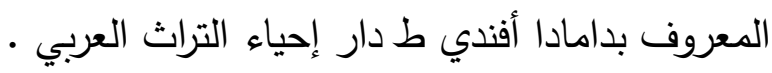

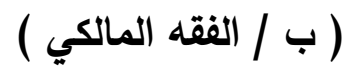

1- بداية المجتها ونهاية المقتصد لأبو الوليد محمد بن أحمد بن رشد القرطبي

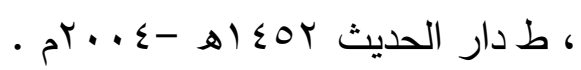

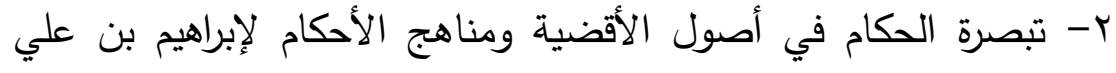
برهان الدين ابن فرحون اليعمري ، ط مكتبة الكليات الأزهرية الطبعة الإنية

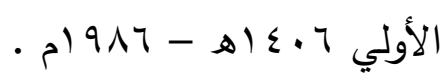


r- حاشية الخرشي شرح مختصر خليل لمحمد بن عبد الله الخرشي ط دار

الفكر

ع- حاشية العدوي علي كفاية الطالب لأبو الحسن بن علي الصعيدي

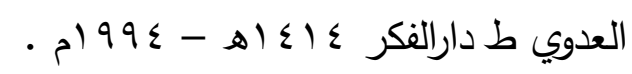

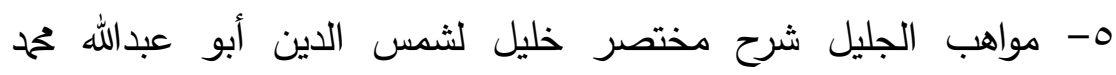
عبدالرحمن الطرابلسي المعروف بالخطاب ، ط دار الفكر الطبعة الثالثة

$$
\text { - مो9r- أه }
$$

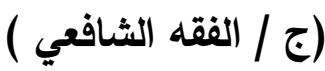

1- أسني المطالب في شرح روض الطالب لزكريا بن حمح ابن زكريا

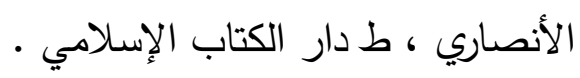

r- حاشية الجمل على شرح المنهج للشيخ سليمان بن عمر الجمل ط دار الإدي - الفكر

r- الحاوي الكبير لأبو الحسين علي بن ححمد بن حبيب البغدادي الثهير

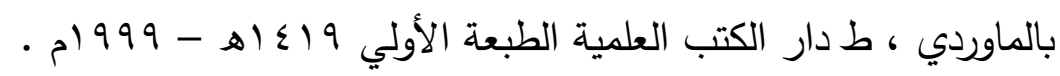

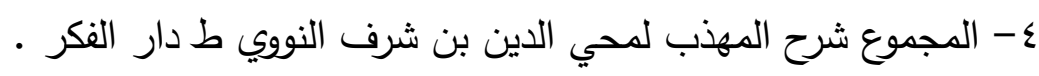

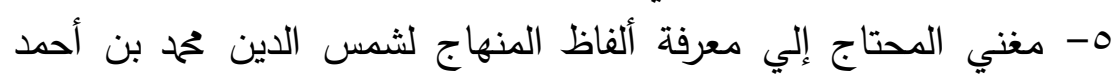

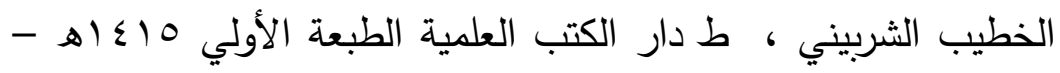
- م) 998

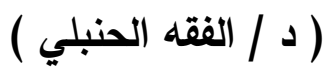

1- إعلام الموقعين عن رب العالمين لمحمد بن أبي بكر بن شمس الدين بن

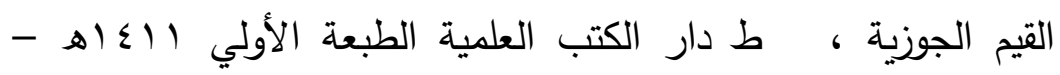
- م) 991

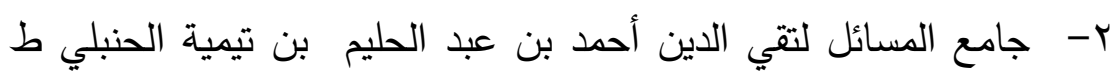

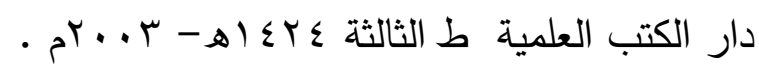

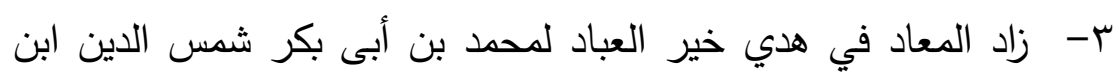

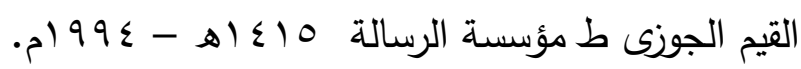




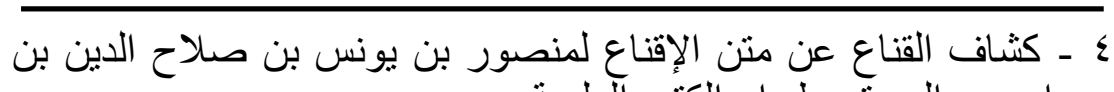

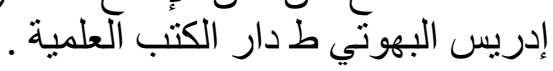

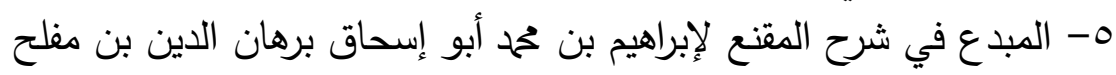

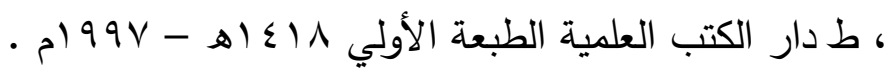

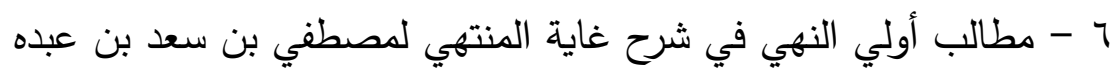

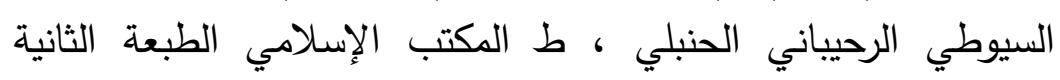
. 10 V- المغني لموفق الدين عبد الله بن أحمد بن قدامة المقسى ط مكتبة القاهرة .

خامساً : قواعد الفقه وأصوله 1-الأحكام في أصول الأحكام لأبو الحسين علي بن سالم الآمدي ط الأه

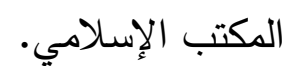

r- أداب الفتوى والمفتي والمستفي لأبو زكريا محي الدين بن شرف النووي

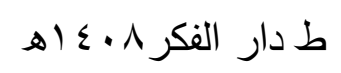

r- أدب المفتي والمستفتي لعثمان بن عبد الرحمن أبو عمرو تقي الدين

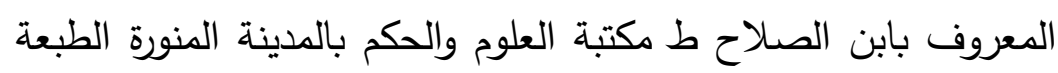

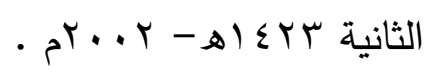

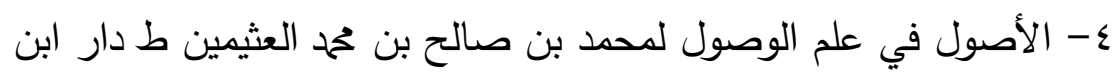

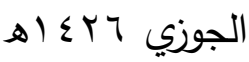

0- البحر المحيط في أصول الفقه لأبو عبدالله بدر الدين بن بهادر

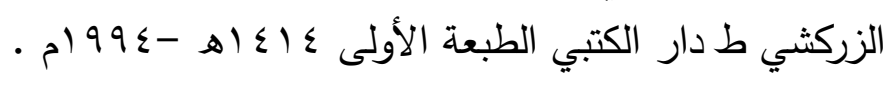

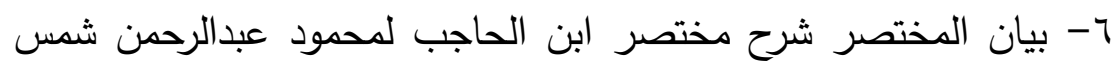

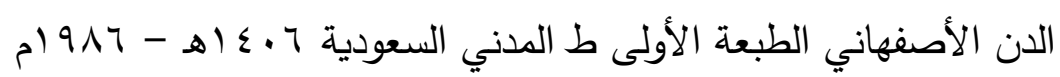

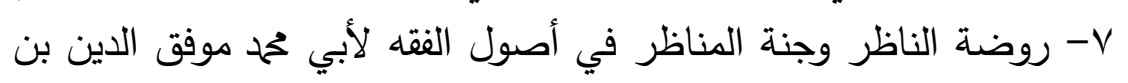

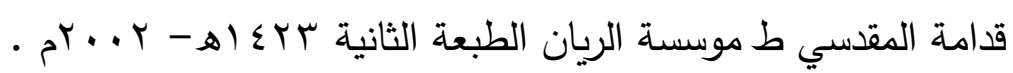
^- شرح القو اعد الفقهية لأحمد بن محمد الزرقان طان دار القلم الطبعة الثانية . $1919-1 \leq .9$ 


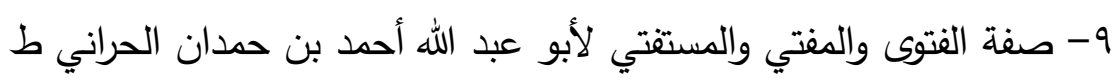

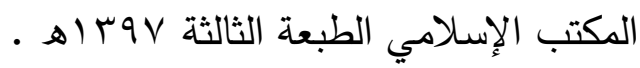
• 1- الفروق لأبو العباس شهاب الدين أحمد بن إدريس بن عبدالرحمن

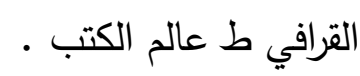

1 1- الفقيه والمتفقه لأبو بكر أحمد بن علي الخطيب البغدادي ط دار ابن

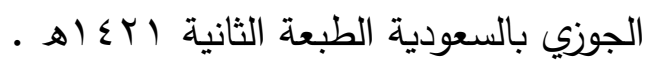

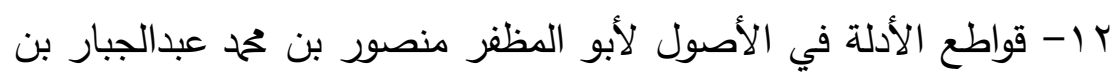

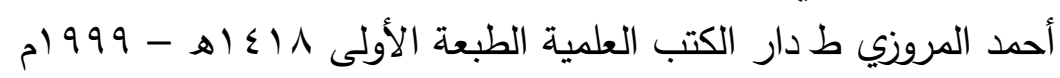

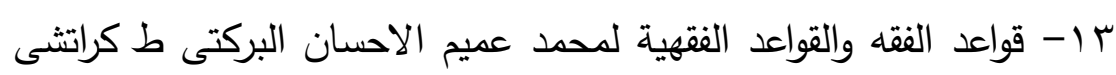

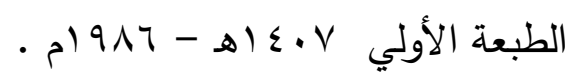

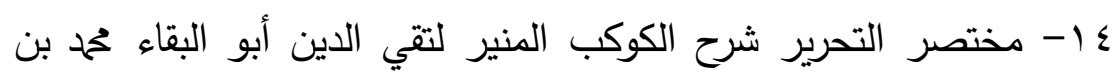

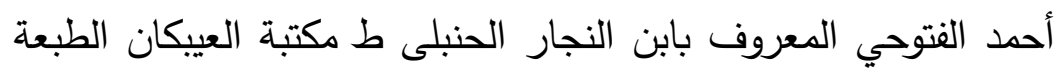

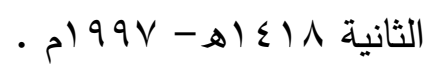

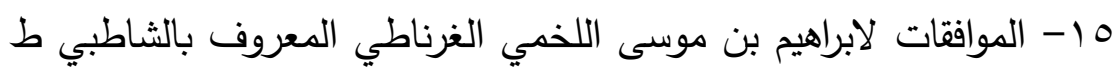

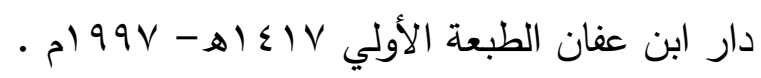

17 - نظرية المقاصد عند الإمام الثاطبي لأحمد الريسونى ط الدار الدار العالمية

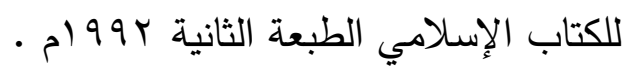

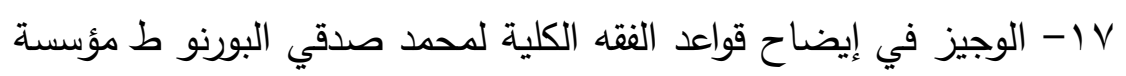

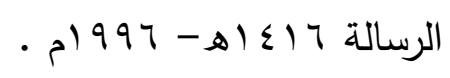

سادساً : اللغة والمعاجم

1- التعريفات لعلي بن حمحة بن محمد الجرجاني ط دار الكتب العلمية الطبعة

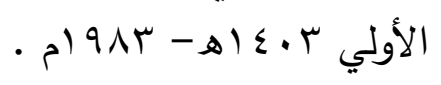

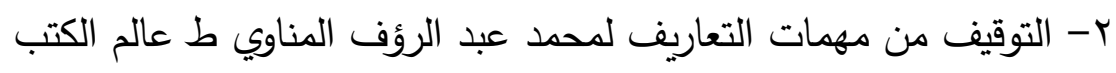

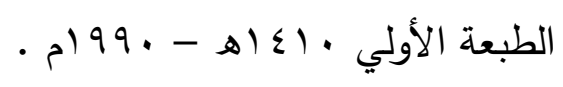

r- العين للخليل بن أحمد الفراهيدي البصري ط دار ومكتبة الهلال . مأل 
ع - القاموس الفقهي لغة واصطلاحا لسعدي أبو جيب ط دار الفكر الطبعة

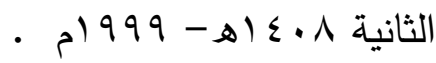

0- لسان العرب لأبو الفضل جمال الدين بن منظور الأفريقي طدار صادر

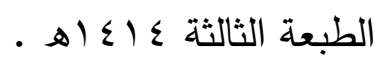

צ- المفردات في غريب القرآن للراغب الأصفهاني ط دار القلم الطبعة

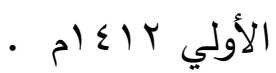

- المصباح المنير في غريب الثرح الكبير لأحمد بن تحمد بن الفيومي ط المكتبة العلمية ^- معجم اللغة العربية المعاصرة لأحمد مختار عبد الحميد عمر ط عالم

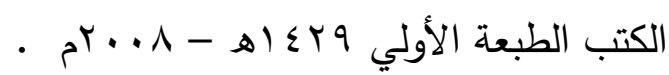

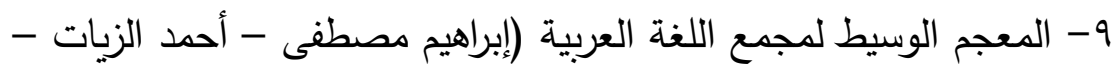
حامد عبدالقادر - حمح النجار ط دار الدعوة . • 1- معجم لغة الفقهاء لمحمد رواس قلعه جي ط دار النفائس الطبعة الثانية

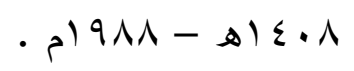

1 - 1 - معجم مقاييس اللغة لأحمد بن فارس بن زكريا القزويني ط دار الفكر

$$
\begin{aligned}
& \text { م) } 9 \vee 9-81499 \\
& \text { سابعاً : التراجم والأعلام }
\end{aligned}
$$

ا- أُسد الغابة في معرفة الصحابة والأبو الحسن على بن أبى الكرم الثيبانى

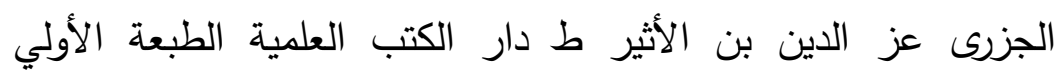

$$
\text { - } 99 \varepsilon-8 \leqslant 10
$$

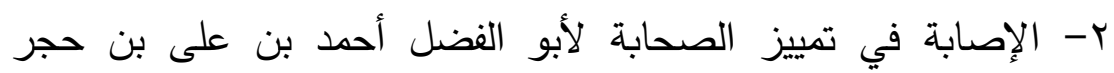

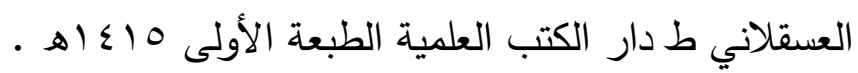

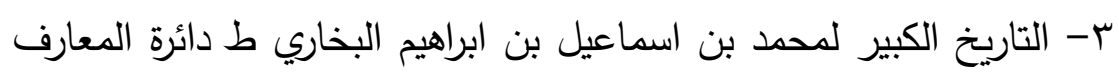
العثمانية

ع- تهذيب التهذيب لأبو الفضل أحمد بن علي بن حجر العسقلاني ط دائرة

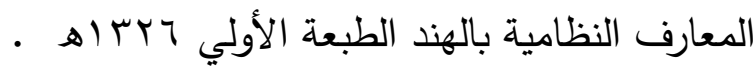


ه- معرفة الصحابة لأبو نعيم أحمد بن عبد الله الأصفهاني ط دار الوطن

$$
\text { م) } 991-81 \leq 19
$$

ثامناً : المراجع العامة

1- أثر الانترنت على الأمن الفكري د / عبدالله محمد الثهري ورقة عمل مقدمة للملتقى العلمي نحو استراتجية الأمن الفكري والثقافي في العالم

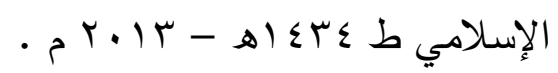

r- أثر الفتوى في المجتمع ومساوى الثذوذ في الفتاوى للدكتور / محمد أحمد بن صالح الصالح بحث مقدم لمؤتمر الفتوى وضوابطها المجمع الفقهي

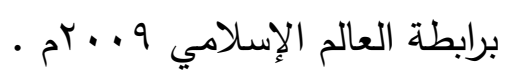

r- استراتيجية تعزيز الأمن الفكري للدكتور متعب بن شديد الهماشى بحث بـث

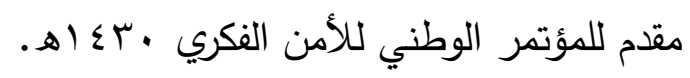

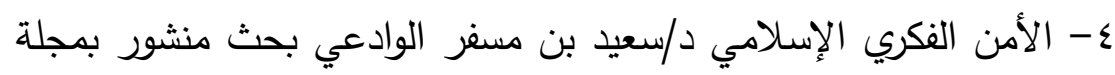

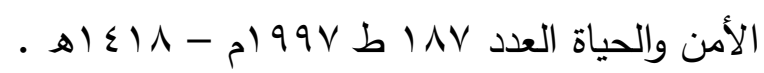

0- الأمن الفكري ماهيته وضابطه لعبد الرحمن بن معلا اللويحق الطبعة الهاه

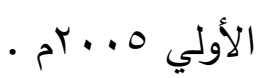

צ- الأمن الفكري وهيئة الأمر بالمعروف والنهي عن المنكر د/عبدالله بن

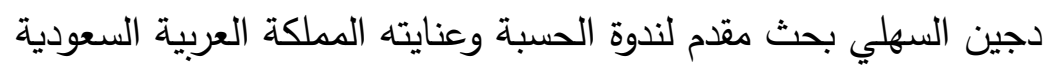
V- تعزيز دور المسجد في الأمن د/هشام عبد الملك آل الثيخ مقال بجريدة

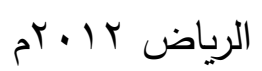

^- دور الأسرة في أمن المجتمع د/ جاسم الياقوت مقالة بجريدة اليوم

$$
\text { • }
$$

9 - دور حلقات تحفيظ القرآن الكريم في تعزيز الأمن الفكري رؤية مستقبليه د/ على بن فايز الجحني ورقه عمل مقدمة للملتقى الرابع لتحفيظ القرآن

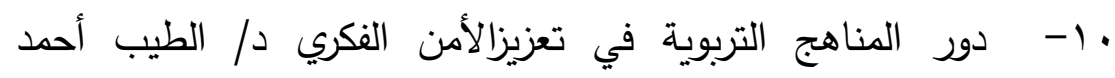

$$
\text { المصطفي بدون طبعة. }
$$


11- الثذوذ في الفتوى وآثره علي الأمن الفكري للمجتمعات الإسلامية وغير

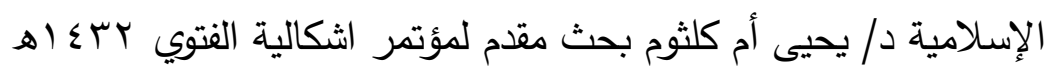

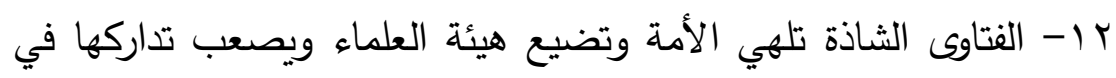

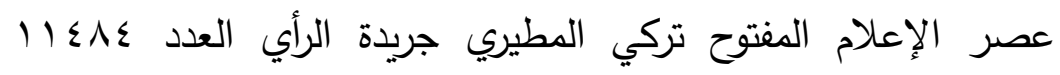

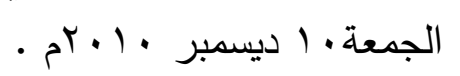

rا - الفتاوى الثاذة مفهومها وأنواعها وأسبابها وآثرها د/ أحمد محمد الهليل

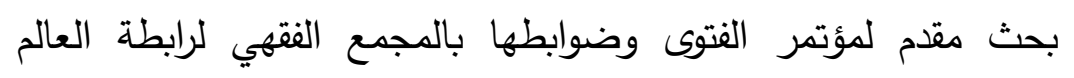

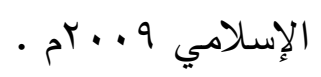

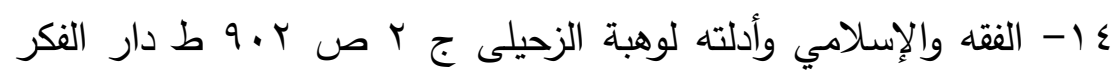

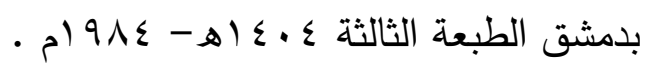

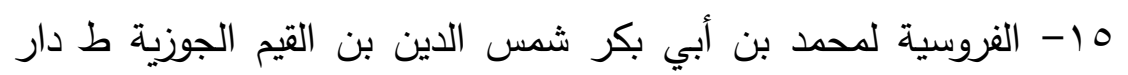

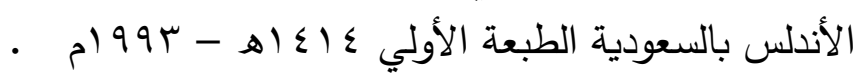

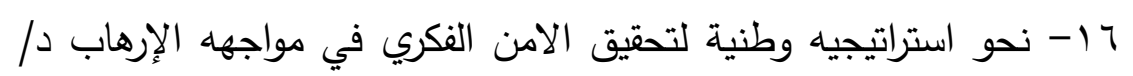

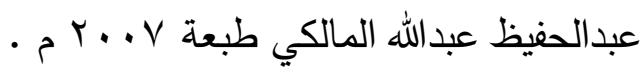
IV - مجموع الفتاوى لابن تيمية ط مجمع الملك فهد لطباعة المصحف

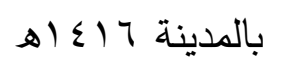

11 - المستدرك على مجموع فتاوى شيخ الإسلام لتقي الدين لأبو العباس

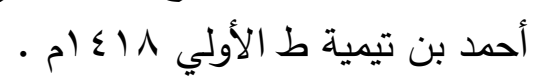

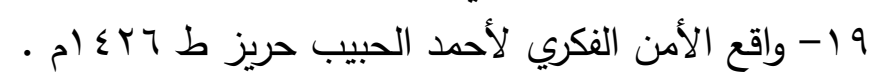

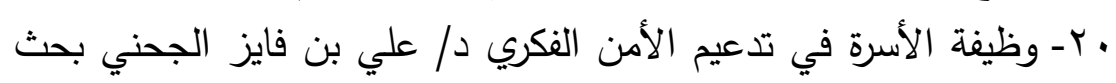

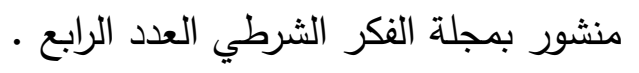
ثامنا: شبكة الأنترنت

1- www. Azhar. egK

2 - www. Alifta. Net

3 - http://www.assakina.com 


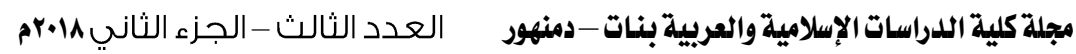

فهرس الموضوعات

\begin{tabular}{|c|c|c|}
\hline الصفحة & 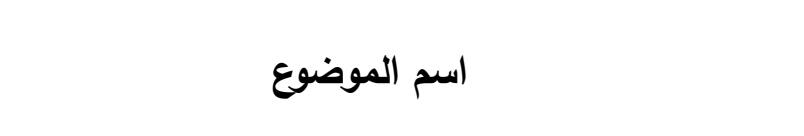 & b \\
\hline 10 & مقدمة & 1 \\
\hline r. & الفصل الأول & r \\
\hline Y & المبحث الأول (تعريف الفتاوي الثاذة ) & $r$ \\
\hline$r \varepsilon$ & المبحث الثاني (تعريف الآثر) & $\varepsilon$ \\
\hline ro & المبحث الثالث (تعريف الأمن الفكري) & $\bullet$ \\
\hline rV & الفصل الثانى & 7 \\
\hline r^ & المبحث الأول ( أهمية الفتوى ) & $v$ \\
\hline $\boldsymbol{\mu}$ & المبحث الثاني ( شروط الفتوى ) & $\wedge$ \\
\hline ro & المبحث الثالث ( أسباب شذوذ الفتوي ) & q \\
\hline$\varepsilon 1$ & المبحث الرابع ( معايير وصف الفتوي بالثذوذ ) & 1. \\
\hline$\Delta V$ & الفصل الثالث & 11 \\
\hline$\bullet \wedge$ & المبحث الأول ( أهمية الأمن الفكري ) & ir \\
\hline $7 r$ & المبحث الثاني (الجهات المنوطة ببث الأمن الفكري) & ir \\
\hline 77 & المبحث الثالث ( آثر الفتاوي الثاذة علي الأمن الفكري ) & $1 \varepsilon$ \\
\hline VI & المبحث الرابع ( بعض قرارات مجمع الفقه والمؤتمرات الخاصة بالإفتاء ) & 10 \\
\hline$\vee 7$ & الخاتمة والتوصيات & 17 \\
\hline$\vee q$ & فهرس المراجع & iv \\
\hline$\wedge \wedge$ & فهرس الموضوعات & 11 \\
\hline
\end{tabular}

